\title{
LIETUVOS KARIUOMENĖS VADOVYBĖS \\ 1933 M. PABAIGOJE-1934 M. PRADŽIOJE \\ INICIJUOTAS LENKIŠKAI KALBANČIŲ TRAKUৃ \\ (KAIŠIADORIŲ) APSKRITIES GYVENTOJŲ TYRIMAS
}

\author{
Prof. habil. dr. Alfonsas Eidintas \\ Generolo Jono Žemaičio Lietuvos karo akademija \\ Olijardas Lukoševičius \\ Kaišiadorių muziejus
}

Anotacija. Lietuvos kariuomenès vadovybès iniciatyva $1933 \mathrm{~m}$. pabaigoje laiškus su anketomis „Lenku pasienio tyrimo reikalu“ gavo pasienio apskričiu - Utenos, Ukmerges, Traku, Alytaus, Marijampoles ir Vilkaviškio - karo komendantai. Vyriausiojo štabo valdybos II (informacijos) skyriaus vadas plk. ltn. Juozas Lanskoronskis, parengęs atitinkama palei administracinę linija su Lenkija ịsikūrusiu gyventojų tyrimo plana, 1933 m. lapkričio 2 d. (gruodžio 2 d. pakartotinai) išsiunte prašyma atsakyti $i$ anketos klausimus ir atsakymus atsiusti iki gruodžio $20 \mathrm{~d}$. Karo komendantai, kaip pareigūnai, esantys arčiausiai gyventojų, turèjo surinkti duomenis ir ivertinti kariuomenes vaidmeni puoselejant lietuvybę.

Vyr. štabo viršininkas įsake parengti studiją, surinkus statistinius duomenis apie pastaruosius 6-7 metus: kiek „lenkuojančiu“" yra tapę neabejotinais lietuviais, kiek yra svyruojančiu, kiek nepalankiu, nes kariuomenès vadovybè turëjo žinoti, ar gali kilti grèsmių iš lenkų tautinès mažumos, ar ji bus lojali krizés metu. Pažymèta, jog toks žinių rinkimas neturi iškilti i viešumą.

Straipsnyje analizuojami iš Traku apskrities paštininkų, mokytojų, kunigu, agronomu, policijos valdininku surinkti duomenys apie Traku apskrities (kurios centras buvo Kaišiadorys) gyventojus, ju lietuvinima, Lietuvos kariuomenes vaidmenị lietuvinimo procese, lenkų kalbos vartojima, gyventojų požiūrị i Lietuvos valdžią ir valstybę, lenkakalbių (jie vadinami „lenkuojančiais“, labai retai - lenkais) ryšius su anapus demarkacijos linijos gyvenančiais ju giminaičiais ir pažistamais, jų lojaluma Lietuvai.

Ši unikali archyve rasta byla, kurioje sukaupti atsakymai ị anketos klausimus ir pateiktos karo komendanto plk. Vlado Žutauto išvados, liudija, jog lenkiškai kalbančiu gyventoju lietuvinimas vyko nekoordinuotai. Tai nepaprastai disonuoja su to meto tautininku spaudoje viešinamais aktyviais svarstymais, raginimais 
atlietuvinti „lenkuojančius“ piliečius. Traku apskrityje po šio tyrimo imtasi tarp vietos lenku itin uoliai platinti lietuviška spaudą. Tuo labiausiai rūpinosi pats karo komendantas.

Pagrindiniai žodžiai: Trakų (Kaišiadoriu) apskritis, lenku tautine mažuma, Lietuvos kariuomené, pasienio gyventoju lietuvinimas, administraciné linija ${ }^{1}$, mokyklos, parapijos, spauda.

\section{IVADINIS ŽODIS}

Turime nemažai darbų ir dokumentų rinkinių, skirtų Lenkijos ir Lietuvos dvišaliams santykiams, konfliktui dèl Vilniaus aptarti, abiejų šalių politikos tautinių mažumų atžvilgiu tyrimų. Tačiau toli gražu ne visos temos išnagrinètos, išanalizuotos. Tautų susidūrimas, formuojantis dviem tautinėms valstybėms, buvo užprogramuotas, aprašyti iki tol pasitaikę lietuvių ir lenkų kivirčai dèl kalbos bažnyčiose, viešajame gyvenime vartojimo. Abi pusès, prasidejjus ginkluotiems susiremimams 1919-1920 m., o ir vèliau, suaktyvejus ne tik diplomatinei, bet ir propagandinei kovai, viena kitai negailèjo karčių žodžių. Lietuvių memuarinèje literatūroje apie 1919-1920 m. lenkų ir lietuvių karinius susidūrimus nerandame aprašytų žiauresnių ịvykių, pavyzdžiui, kad Lietuvos kariuomenè brutaliai elgèsi su lenkiškai kalbančiaisiais, nors jègos taikymo atvejų ir būta, nepasitaikè ir etninio valymo epizodų. Netgi pirmajame kovų su gen. Liucjano Želigovskio daliniais etape ypatingų ginkluotų veiksmų nevyko. Akivaizdu, kad želigovskininkai turejo aiškią persvarą, be to, juos rẻmė Vilniaus lenkai, o L. Želigovskio karinei grupei apsaugoti buvo skirtos net dvi Lenkijos armijos ${ }^{2}$. Išimtis - vèliau atribojimo juotose vykęs lenkų karių plěšikavimas, jų partizanų veikla, susidūrimai su Lietuvos šauliais

\footnotetext{
1 Iki $1928 \mathrm{~m}$. lietuviai ją vadino demarkacijos linija.

2 Jokubauskas Vytautas, Vaičenonis Jonas, Vareikis Vygantas, Vitkus Hektoras. Valia priešintis: paramilitarizmas ir Lietuvos karinio saugumo problemos, Klaipėda, 2015, p. 67-68.
} 
ir partizanais ${ }^{3}$, pareikalavę aukų, susišaudymų, taip pat užfiksuota blogo elgesio su belaisviais pavyzdžių.

Suprantama, jog Lietuvos kariuomenès daliniai geriau jausdavosi vietovėse, kurių dauguma gyventojų buvo lietuviai. Ypač tai buvo svarbu partizanams, su kuriais lenkų kariniai daliniai turejo daug problemų, todèl ir su paimtaisiais į nelaisvę jie elgèsi negailestingai. $1920 \mathrm{~m}$. spaudoje pažymima, kad partizanų veiklai „svarbios reikšmès turi vietos gyventoju nusistatymas“, vietose, kur dauguma gyventojų lietuviai, greitai gaunama informacijos, ten galima ilgiau pabūti, vietos gyventojai padeda pasislèpti, ìspejja apie pavojų, neišduoda. Partizanų veiklai etninè gyventojų sudètis ir jų požiūris $\mathfrak{i}$ Lietuvos valstybę buvo labai svarbi aplinkybe் ${ }^{4}$. Tas pats pasakytina ir apie Lietuvos kariuomenès dalinių savijautą kaimuose ir miesteliuose.

Prieš II pasaulinį karą paskelbti Lietuvos kariuomenès karių ir partizanų savanorių atsiminimai yra gal ir kiek paredaguoti prieš publikuojant, nes pasirodè, kai Vilnius jau buvo ịtrauktas ị Lenkijos sudètị ir antilenkiškumas iš esmès tapo svarbiu ideologiniu elementu kovoje dèl prarastos sostinès. Lenkų ir lietuvių konfliktas buvo priimamas kaip nacionalinių valstybių kūrimosi reiškinys, neretai individams nelengvai apsisprendžiant, ị kurios valstybės kariuomenę reikia eiti, o aštrius kampus gludino supratimas, kad abi šios kariuomenès yra katalikiškos, nukreiptos prieš bolševikus, kad jos kartais veikia išvien. Teisus istorikas Zenonas

3 Apie Lietuvos partizanus žr.: Vareikis Vygantas. Pasienio incidentai. Lietuvos šaulių partizaninè veikla, Darbai ir dienos, t. 40, Kaunas, 2004, p. 109-128; Lesčius Vytautas. Lenkų provokacijos neutralioje zonoje 1921-1923 metais, Karo archyvas, t. XXII, Vilnius, 2007, p. 153-218. Net ir 19201128 įsteigus neutralią 6-12 km pločio zoną tarp Lietuvos ir Lenkijos kariuomenių taikūs santykiai neịsivyravo iki pat $1923 \mathrm{~m}$. pavasario. Lenkija nukreipė agresyvius veiksmus trimis pagrindinėmis kryptimis - i Suvalkijos pietus, Valkininkų-Rūdiškių geležinkelio ruožą ir Širvintų-Giedraičių kraštą. Nuo lenkų antpuolių ypač kentèjo vietos gyventojai. Zonos statusą prižiūrèjo Tautų Sąjungos komisija, tad Lietuva negalejo ten pasiųsti kariuomenès dalinių. Susiorganizavę zonos gyventojai lietuviai, visų pirma šauliai, milicija buvo per silpni priešintis lenkų ginkluotiems būriams, siekiantiems užimti zoną ir skverbtis ị Lietuvos gilumą. Kadangi lenkai siuntė perrengtus civiliais savo karius, lietuviai atsakè tuo pačiu - perrengdavo karius civiliais (taip padarè IV pèst. divizija (štabas Alytuje) ir III pèst. divizija (štabas Kaišiadoryse). Perrengti civiliais kariai ir karininkai, dalyvavę kovose su lenkais, taip pat vadinosi partizanais.

4 Jokubauskas Vytautas. Netiesioginis poveikis ir Lietuvos karinis saugumas 19191940 m., Klaipèda, 2019, p. 290. 
Butkus, rašydamas, jog Lenkijos ir Lietuvos konfliktas nebuvo vien pasienio teritorinis ar etninis ginčas, - jis kilo ne dèl abiejų tautų nesantaikos, nesugyvenimo ar kokių nors pasienio gyventojų susidūrimų, smurto proveržių. Jị sukèlè politinès aplinkybès, Lenkijos siekis atkurti bendrą Lietuvos ir Lenkijos valstybę ir pastarosios pastangos vykdyti arba bent mégdžioti didžiosios valstybès politiką ${ }^{5}$. Konfliktui plisti sąlygas sudarè Vokietija ir SSRS, Vokietija netiesiogiai padejo Lenkijai įsitvirtinti Vilniuje, o sovietai, $1921 \mathrm{~m}$. taikos sutartimi su Lenkija kaip ir atidavę Vilnių, paspende abiem šalims konflikto gilinimui palankius spąstus.

Gyvenimas šimtmečiais bendroje valstybejje, kalbiniai ir etniniai pakitimai padare savo - ginkluoto konflikto metu Lietuvos ir Lenkijos kariniai daliniai kartais nesusigaudydavo, kurios šalies teritorijoje veikia, - vienų kaimų gyventojai kalbėjo lenkiškai, kitų - lietuviškai. Buvusios Lietuvos Didžiosios Kunigaikštystės (LDK) teritorijoje atrandamos lietuviškai ar lenkiškai kalbančiujų salos ar netgi teritorinės juostos. Lietuvos teritorija rytuose ir ypač pietuose kalbiškai nebuvo vienalytè, todèl lietuvių ir lenkų daliniai iš tiesų kartais nežinojo, kokios valstybès teritorijoje yra - abiem pusèms dažnai būdavo neaišku, kur prasideda ir kur baigiasi pasienis ${ }^{6}$. Žinoma, čia neturime omenyje sąjungininkų nubrèžtų kelių demarkacijos linijų, jų nustatytų tarp Lietuvos ir Lenkijos kariuomenių (šias linijas lenkai pažeidinejjo, o lietuviai dèl to reiškè protestus sajungininkams ar jų karinèms misijoms).

Kaireje Nemuno pusejje pasieniu būtų galima laikyti 1919 m. gruodžio $8 \mathrm{~d}$. Antantès (Santarvès) Aukščiausiosios Tarybos nustatytą liniją, tačiau ji netenkino abiejų konfliktuojančių pusių. Lenkų ir lietuvių kariuomenès keletą kartų ją peržengė judèdamos pirmyn ir atgal, nesuvokdamos, kur yra tikra skiriamoji riba. Tačiau abi pusès būtinai norejo ịrodyti savo viršenybę.

Nelengva buvo tiksliai nusakyti kalbines ribas ir Pietų Suvalkijoje. Lietuviai šiltai sutikti prie Seinų, apie Beržininkus, „nes vietiniai buvo tikri lietuviai ir jie mums suruoše pietus. Pietų valgyti paleidome pusę

5 Butkus Zenonas. Tarp Trečiojo Reicho ir Trečiosios Romos. Vokietijos ir sovietu politikos poveikis Baltijos šaliu tarptautinei ir vidaus padéčiai tarpukaryje, Vilnius, 2019, p. 450. 6 Laurinavičius Česlovas. Politika ir diplomatija: lietuviu tautines valstybès tapsmo ir raidos fragmentai, Kaunas, 1997, p. 249-250. 
kareivių, o kiti likome apkasuose. Sugrižus pirmiesiems, mes nuejome. "

Stasys Tomkevičius prisiminè, jog žvalgant Augustavo-Suvalkų plentą, ar nèra užsilikusių lenkų kareivių, pakelyje tarp Suvalkų ir Augustavo, paplentejje, viename kaime „žmonès mus kalbino lietuviškai, prièmè su duona ir druska ir labai mumis džiaugèsi“"

Lietuvos kariuomenè savaime stiprino lietuvybę ir skatino nelietuviškai kalbančių gyventojų lojalumą valstybei, tačiau pilietine prasme integruoti tautines mažumas, kur jos gyveno kompaktiškiau, ypač prie administracinès linijos su Lenkija, kaimuose, buvo nelengva. Bendrą mūsų nagrinejamojo rajono situaciją, ypač akcentuodamas jo prastą ekonominę padètị dèl ilgalaikių karo veiksmų, yra nušvietęs Olijardas Lukoševičius. Trakų apskrityje, pasienio ruože, Vievio, Semeliškių, Aukštadvario ir Onuškio valsčiuose, dalis gyventojų kalbejo lenkiškai arba gudiškai, faktiškai dèl to prie demarkacijos (administracinès) linijos su Lenkija buvusiems valsčiams ir buvo įkurtas II švietimo rajonas, čia sunkiau formavosi lietuviška savivalda ${ }^{9}$.

To meto tautybių statistika sunku pasitikèti - nors $1921 \mathrm{~m}$. Semeliškių valsčiaus taryboje nurodyta esant 16 lietuvių, posėdžiai vyko lenkų kalba, o milicijos vadui paklausus, kodèl posèdžiaujama lenkiškai, buvo atsakyta: „My nie razumiem po litewsku. “ ${ }^{10}$ („Mes nesuprantame lietuviškai.“)

Kuriant savivaldybes valsčiuose tarp lietuvių ir lenkiškai kalbančiųjų kildavo nesutarimų dèl vietų komitetuose, neretai vietos gyventojai kovodavo abiejose fronto pusėse (iš Kaišiadorių valsčiaus ị Lenkijos kariuomenę 1919-1922 m. išèjo 18 vyrų, iš Žaslių valsčiaus - 13, lietuvių manymu, jie buvo „dvarininkai, nesusipratę dvarų darbininkai ir vienas kitas miesčioniukas"11. Vykstant kovoms su lenkais, valsčiai eidavo iš rankų i rankas, abi pusės reikalaudavo ne tik gyventojų paklusnumo, bet ir prievolių vykdymo. Lenkai agitavo ir kvietė jaunuolius ị legionus net grynai lietuviškuose kaimuose, lietuviai rinko žinias apie nelojalius Lie-

\footnotetext{
7 Savanoriu žygiai, Nepriklausomybès karų atsiminimai. Sudarytojas Petras Ruseckas. 2 t., Vilnius, 1991, p. 74.

8 Savanorių žygiai..., 2 t., p. 126.

9 Lukoševičius Olijardas. Trakų (Kaišiadoriu) apskritis 1918-1940 m.: tarp valdžios ir savivaldos, Kaišiadorys: Kaišiadorių muziejus, 2019, p. 748.

10 Ten pat, p. 185.

11 Stosiūnas Bronius. Lietuvai besukuriant, Karo archyvas, t. IX, p. 317.
} 
tuvai lenkus, kariuomenės naujokus, jų lojalumą. Nenuostabu, kad augo tarpusavio nepasitikejjimas ir aštrejo santykiai tarp gyventojų, juo labiau kad lietuvių milicija vis dažniau krète lenkų dvarus ${ }^{12}$. Netgi tuose miestuose ir miesteliuose, kurių apylinkèse dominavo lietuviai, pirmaisiais nepriklausomybès metais kildavo sunkumų dèl lietuvių kalbos vartojimo. Žemaitijoje - Telšiuose, pasak liudininko, vietos šaulių vado Povilo Dirkio, „vietos valdininkai vengé lietuviškai kalbėti. Dauguma jų turèjo mišrias šeimas. Be to, apie 12 to laiko vietos valdininkų, įskaitant ir patị komendantą, kalbejo rusiškai ar vokiškai, sakydami, kad jie nemoka gerai lietuvių kalbos. Dar blogesnè padètis buvo viešo nugèrimo progomis. Atrodè, kad čia nèra Lietuvos valstybė, o tik jos atkūrimo parodija." ${ }^{33}$

Vis dar stokojame darbų apie kasdienị Lietuvos lenkų gyvenimą, jų pastangas išlaikyti savo kalbą ir kultūrą ar, atvirkščiai, „lietuvèjimą“, Lietuvos valdžios ir visuomeninių organizacijų atstovų pastangas „lenkuojančius“ gyventojus (lenkiškai kalbančius, suprask, ne tikrus lenkus, o kažkada sulenkintus lietuvius) integruoti, kad jie taptų visuomenès dalimi. Apie lenkų patirtas skriaudas yra rašę Lietuvos lenkų autoriai, ypač F. Lenkutis XX a. 4 dešimtmetyje, daugiausia nagrinėdamas kovų už lenkiškas mokyklas temą ${ }^{14}$. Panašiai ir Lietuvoje vietos lenkų tautinès mažumos situacija nagrinèta per jų mokyklų istoriją - švietimo aspektą tirti pradejjo istorikas B. Šetkus ${ }^{15}$, šị darbą pratęsè S. Kaubrys, analizavęs Lietuvos mokyklų 1918-1939 m. ypatumus.

S. Kaubrys bus bene pirmasis, aptaręs mums rūpimo Trakų (Kaišiadorių) rajono specifiką, atkreipęs demesị i kariuomenès vadovybès iniciatyva vykdytą tyrimą Trakų apskrityje ir 1934 m. pradžios siūlymus, kaip padaryti efektyvesnes lietuviškas mokyklas, parengti vietos inteligentus darbui, priimtas rekomendacijas siųsti lietuvių mokytojų í lenkų gyvenamas vietoves. Net ir cituodamas tyrimo rekomendacijas ir prel. J. La-

12 Lukoševičius Olijardas. Traku (Kaišiadorių) apskritis 1918-1940 m.: tarp valdžios ir savivaldos, Kaišiadorys, 2019, p. 81,76, 74-75, 70-71; Lukoševičius Olijardas. Palomenès istorija: XX amžius, Kaišiadorys: Kaišiadorių muziejus, 2015, 320 p.

13 Dirkis Povilas. Partizanus ir šaulius prisimenant, Nepriklausomai Lietuvai. Red. Petras Petrušaitis, Chicago: Lietuvos šaulių sąjunga tremtyje, 1965, p. 119.

14 Lenkutis F. Walka o polską szkole w Litwie. Polacy Zagranyca, 1930, No 10.

15 Šetkus Benediktas. Lietuvos vyriausybės požiūris ị lenkų tautinės mažumos mokyklas Lietuvoje 1919-1940, Lietuvos rytai. Red. K. Garšva, L. Grumadienè, Vilnius, 1993. 
buko siūlymus, knygos autorius nenurodè, kokiu konkrečiai spaudiniu, šaltiniu ar archyvine byla rèmèsi. S. Kaubrys pažymèjo, kad panašių vertinimų ir siūlymų buvo pateikta Alytaus apskrities policijos nuovadų raportuose apskrities viršininkui, raginant steigti krašte daugiau amatu mokyklų ${ }^{16}$. Lietuvos valdžia, ypač tautininkai, dažniausiai nelaikè lenkiškai kalbančių Lietuvos gyventojų lenkais, o tik sulenkintais lietuviais, teigè B. Ivanovas ${ }^{17}$, vèliau - lenkų istorikas K. Buchowskis ${ }^{18}$, aprašę abipusius tarpusavio santykių vertinimus, polemiką spaudoje ir paskirų autorių koncepcijas. Kartu buvo aptartos Lietuvos kariuomeneje tarnavusių lenkų lietuvejimo tendencijos ${ }^{19}$.

Šiame straipsnyje, kur pirmą kartą analizuojama konkreti faktinė medžiaga apie pasienio gyventojus lenkus, bandysime panagrinèti, kaipgi atrodè respondentams lituanistinis poveikis po 12 metų, kovoms dèl nepriklausomybės pasibaigus Trakų (Kaišiadorių) apskrityje. Tai padaryti leidžia $1933 \mathrm{~m}$. pabaigoje Lietuvos kariuomenès inicijuota unikali lenkiškai kalbančių pasienio zonos gyventojų Trakų (Kaišiadorių) apskrityje apklausa, kurią atliko apskrities karo komendantas per patikimus, savo pasirinktus, respondentus. Remiantis medžiaga, kurią archyve rado O. Lukoševičius, taip pat lietuvių surinktais faktiniais duomenimis ir jų pateiktais vertinimais bei siūlymais šiame straipsnyje ir apžvelgiama lenkiškai kalbančių gyventojų padetis Lietuvos ir Lenkijos pasienio zonoje.

16 Kaubrys Saulius. Lietuvos mokykla 1918-1939 m.: Galios gimtis, Vilnius, 2000, p. 131132.

17 Ivanovas Bernaras. Tautiškumo beieškant Antano Smetonos Lietuvoje. Tautiniu įvaizdžių klausimas, Vilnius, 2005, 344 p.

18 Buchowski Krzysztof. Litvomanai ir polonizuotojai. Mitai, abipusés nuostatos ir stereotipai lenkų ir lietuviu santykiuose pirmoje XX amžiaus puseje, Vilnius, 2012, 603 p.

19 Remiantis O. Lukoševičiaus nuoroda ị šią medžiagą archyve, aptartas tik vienas aspektas - Lietuvos kariuomenès lietuvinimo poveikis Lietuvos lenkams karo tarnybos metu. Žr.: Eidintas Alfonsas, Lopata Raimundas. Valstybès atkūrimo istorijos, Vilnius: MELC, 2020, 552 p. Žr. paskutinị A. Eidinto parašytą knygos skyrių, p. 449-457, apie Lietuvos kariuomenès santykius su lenkakalbiais gyventojais. 


\section{ANKETOS „LENKŲ PASIENIO TYRIMO REIKALU“ PARENGIMAS}

1933 m. lapkričio 2 d. Lietuvos kariuomenès Vyriausiojo štabo II (informacijos) skyriaus viršininkas plk. Juozas Lanskoronskis ${ }^{20}$ atsiuntė Trakų (Kaišiadorių) apskrities komendantui plk. ltn. Vladui Žutautui savo parengtą anketą - klausimyną „Lenkų pasienio tyrimo reikalu“, - kurios ¡žangoje buvo pabrèžta:

„Su pasigailejimu tenka konstatuoti, kad beveik visa lenkų pasienio sritis tebèra gerokai sulenkejjusi. Toks reiškinys, be visokių kitų sumetimų ir valstybinio reikalo tautiškai kraštą stiprinti, sudaro rūpesčio ir išorinès apsaugos reikale. Kol pasienio sritis nèra perdèm lietuviška, krašto apsaugos organų darbas gali turèti didelių spragų ir praktinių sunkumų. Tie sunkumai gali būti ịvairūs, pavyzdžiui, <...> sudaro abejojimų dèl visumos pasienio srities valstybingumo $\langle\ldots\rangle$, sudaro komplikacijų, konfliktui ištikus, sienos uždarymo reikale $<\ldots>$ priešininkui karo metu mūsų teritoriją ịsiveržiant, jis gali rasti palankias sąlygas diversijos darbui (mūsų užnugario ardymui).“

Remdamasis šiais argumentais, jis prašè surinkti kuo daugiau medžiagos apie gyventojų nuotaikas, lietuvybės platinimą, lietuvių kalbos mokejjimą ir pan. ${ }^{21}$

${ }^{20}$ Juozas Lanskoronskis (1893 m., Zasiškiai, Nemunèlio Radviliškio valsčius; 1980 m., Belgija) - Lietuvos karinis veikèjas. $1915 \mathrm{~m}$. Peterburge baigè Istorijos ir filologijos institutą, 1916 m. - Pavelo karo mokyklą. 1917-1918 m. prisidejjo prie Rusijos kariuomenès lietuvių karinių dalinių organizavimo. $1919 \mathrm{~m}$. grịžęs ị Lietuvą ịstojo ị Lietuvos kariuomenę, kovojo su Raudonąja armija, bermontininkais ir Lenkijos daliniais. 19201922 m. - Pirmosios brigados štabo viršininkas. 1922 m. baige Aukštuosius karininku kursus, vèliau juose dèstè. 1922-1923 m. mokèsi Saint-Cyro aukštojoje karo mokykloje Prancūzijoje. 1925-1926 m. - Vyriausiojo kariuomenès štabo Karo mokslo skyriaus viršininkas. 1926-1929 m. mokèsi Belgijos karo akademijoje. 1929 m. - Generalinio štabo pulkininkas. 1930-1934 m. - Vyriausiojo kariuomenès štabo 2-ojo (informacijos) skyriaus viršininkas. 1934-1937 m. - Šeštojo péstininkų pulko vadas ir Klaipèdos igulos viršininkas. Nuo 1937 m. - Lietuvos karinis atašè Prancūzijoje ir Belgijoje. 1940 m. SSRS okupavus Lietuvą, $\mathfrak{i}$ ją negrižzo.

${ }^{21}$ Lenkų pasienio tyrimo reikalu. LCVA, F. 500, Ap. 1, b. 406, 1. 492. 
Plk. J. Lanskoronskis 1933 m. gruodžio 2 d. raštu priminė lapkričio 2 d. siųstą anketą ir paprašè, kad karo komendantai atsiųstų atsakymus iki gruodžio 20 d. ir toliau rinktų medžiagą, nes kariuomenès Vyriausiojo štabo valdybos II skyrius parengè atitinkamą rytinei Lietuvos administracinei linijai tirti planą, kadangi reikia ịvertinti lietuvinimo darbo rezultatus ir ateityje ši darbą dirbti, įvertinti kariuomenès vaidmenį ugdant lietuvybę.

Vyr. štabo viršininkas įsake ị ši darbą ịtraukti apskričių karo komendantus, kurie artimiau bendrauja su vietos gyventojais, nes medžiagos reikia surinkti kuo daugiau ir ja remiantis parengti studiją. Dèl to pravartu apsilankyti labiausiai sulenkejjusiuose valsčiuose, miesteliuose, kaimuose, pasikalbèti su pareigūnais, inteligentais. Išvadas būtina pagrịsti statistikos duomenimis: „Pavyzdžiui, nustatyti skaičiais, koks vaizdas gaunasi per paskutinius 6-7 metus - kiek lenkuojančių yra pasidarę visai neabejotinais lietuviais, kiek svyruojančių, kiek visai nepalankių ir t. t.“ Žinių rinkimo nenutraukti, bet tai neturi iškilti viešumon ${ }^{22}$.

Laiškus su anketomis gavo kai kurių su Lenkija besiribojančių pasienio apskričių - Utenos, Ukmergès, Trakų (Kaišiadorių), Alytaus, Marijampolès ir Vilkaviškio - karo komendantai (paryškinta aut.). Tarp adresatų nepaminèta Lenkijos pasienyje buvusi Zarasų apskritis, Seinų (Lazdiju) apskrities tyrimo ataskaita sujungta su Alytaus apskrities ataskaita galbūt dèl to, kad i Lietuvos kariuomenès vadovybę dèl prašymų atsiųsti lietuviškos spaudos ir kitų leidinių ne kartą kreipèsi tik Kaišiadorių, Alytaus, Ukmergès ir Utenos karo komendantai ${ }^{23}$.

Trumpai aptarsime tik Trakų apskrityje (kurios centras buvo Kaišiadorys) apie kariuomenès vaidmenį lietuvinimo procese surinktus duomenis. Anketoje „Mūsų su lenkais pasienio tyrimo reikalu“24 (žr.: 1 priedą) ypatingas dėmesys kreiptas ị lenkų kalbos vartojimą, t. y. „lenkuojančius“ gyventojus, tradiciškai nepripažịstant, kad tai ne vietos lenkai, o tik per amžius sulenkèję lietuviai, jų lojalumą Lietuvai, spaudos prenumeratą, ryšius su anapus demarkacijos linijos gyvenančiais žmonėmis, Lietuvos valdžios įstaigų, Bažnyčios, organizacijų daromą ịtaką lietuvinimui.

\footnotetext{
22 Ten pat, 1. 491, 494 ir kt.

23 Kariuomenès štabo Spaudos ir švietimo skyriaus viršininko 19360423 raštas Kaišiadorių apskrities komendantui. Ten pat, 1. 498.

24 Ten pat, 1. 487.
} 
Anketą, sudarytą iš daugybès klausimų, 1933 m. pabaigoje gavęs Trakų (Kaišiadorių) apskrities karo komendantas V. Žutautas ${ }^{25}$ išsiunte patikimiems asmenimis, jam gerai žinomiems apskrities pareigūnams, mokytojams, kunigams, pašto viršininkams ir kitiems, prašydamas atsakyti ị pateiktus klausimus. Respondentus jis pasirinko savo nuožiūra, selektyviai.

Ši tyrimą atlikti neabejotinai paskatino nauji vidaus politikos reiškiniai ir tarptautiniai ịvykiai. 1933 m. pagrindinis Lietuvos vyriausybès rūpestis buvo šalies viduje nacionalistinių ir nacionalsocialistinių vokiečiu organizacijų veiklos prieš Lietuvos suverenitetą ir lietuviškumą suaktyvėjimas Klaipèdos krašte ${ }^{26}$. Situacija autonomiją turinčiame regione prastẻjo, centrinès valdžios ịtaka krašte silpo, vokiškos organizacijos diktavo savo valią, lietuvių kalba buvo vartojama tik lietuviškuose kolektyvuose, moksleiviai rinkosi vokiškas mokyklas. Vokietija rémé nacionalistu veiklą, ne veltui „vokiškajji veiksnị “ valstybès saugumui Lietuvoje imta suvokti kitaip negu anksčiau, nes ilgus metus pavojingiausiu laikytas tik „lenkiškasis veiksnys“.

1933 m. spali Vokietija išstojo iš Tautų Sajungos ir paliko nusiginklavimo konferenciją, o gruodžio $18 \mathrm{~d}$. Vokietija pareikalavo pakeisti visus Versalio sutarties straipsnius, susijusius su karinėmis problemomis: leisti

25 Žutautas Vladas (1896 m. Joteikių k., Butkiškių par., Kauno gub.; žuvo 1941 m. gruodžio mèn. Sibire, Rešiotų 7-ame lageryje) - Lietuvos nepriklausomybès kovų dalyvis. Peterburge 1915 m. pašauktas ị carinę kariuomenę. 1916 m. baigè Vilniaus karo mokyklą, kuri tuo metu ịsikūrẻ Poltavoje. Dalyvavo kovose su vokiečiais Rumunijos fronte. Sužeistas pateko ị vokiečių nelaisvę. $1919 \mathrm{~m}$. pradžioje grịžo i̇ gimtinę, o tų metų birželị jau dalyvavo kautynèse prieš bolševikus su Lietuvos kariuomenès 2-uoju pulku. Už narsumą kautynèse prie Dauguvos apdovanotas I laipsnio Vyčio Kryžiumi. 1919 m. spalio mèn. jam suteiktas vyr. leitenanto laipsnis. $1920 \mathrm{~m}$. V. Žutautas perkeltas ị II pėstininkų divizijos štabą. Dalyvavo kovose su lenkais. Baige Aukštuosius karininkų kursus (1922) bei aštuonių klasių gimnaziją suaugusiesiems. $1929 \mathrm{~m}$. paskiriamas Lietuvos karininkų ramovès šeimininku, suteikiant jam pulkininko leitenanto laipsni. $1933 \mathrm{~m}$. paskirtas Trakų apskrities karo komendantu. Vytauto Didžiojo universitete studijavo teisę (studijas baige 1939 m.). 1937 m. apdovanotas Didžiojo Lietuvos kunigaikščio Gedimino ordino 3-iojo laipsnio medaliu. 1940 m. birželio 29 d. pulkininkas leitenantas V. Žutautas perkeltas i Šiaulių apskritị kariniu viršininku; tų pačių metų spalị ši ịstaiga likviduojama. $1941 \mathrm{~m}$. kovo mèn. jis išleidžiamas ị atsargą. $1941 \mathrm{~m}$. gegužès $31 \mathrm{~d}$. NKVD suimtas.

26 Plačiau žr.: Žostautaitè Petronelè. Klaipédos kraštas 1923-1939 m., Vilnius, 1992, p. 101-126. 
padidinti Vokietijos kariuomenę iki 300000 karių (iki tol galëjo turèti tik 100 000), sukurti visų rūšių karinę pramonę, įvesti kariuomenę ì demilitarizuotą Reino zoną. Kol kas Vokietijos karinès pajègos Rytprūsiuose nebuvo didelès, ypač prie Klaipėdos krašto ${ }^{27}$. Galbūt dèl to $1933 \mathrm{~m}$. ¡ Kauną atvykusio Latvijos kariuomenès Generalinio štabo atstovo plk. H. Rozenšteino pasiūlymą apsvarstyti Vokietijos ekspansinių planų grèsmę ir saugumo sustiprinimo priemones Lietuvos kariuomenès vadas gen. Petras Kubiliūnas atmetè. Tačiau neilgai trukus, 1934 m., Lietuvos karinè vadovybè jau rūpinosi galimybèmis atitraukti kai kuriuos dalinius nuo administracinès linijos, skiriančios Lietuvą nuo Lenkijos, kad galima būtų juos dislokuoti prie Nemuno, Vokietijos pasienyje. Šie kariuomenès perdislokavimo planai liudijo Lietuvoje besiformuojančią naują saugumo sampratą $^{28}$. Gen. P. Kubiliūnas 1934 m. sausio mèn. sovietų diplomatui pasakè, kad „dabar Vokietijos puolimo nelaukiama, bet politiškai stiprinama padètis Klaipèdoje ir kariškai - gynybinè vakarų siena: Tauragèje baigiamos statyti kareivinès naujai formuojamam pulkui." ${ }^{29}$ Tais metais buvo sukurti ir keli nauji Lietuvos kariuomenès daliniai - du pėstininkų pulkai, artilerijos pulkas iš Suvalkijos perkeltas ị Žemaitiją, 6-asis pèstininkų pulkas dislokuotas Klaipèdoje, 7-asis - Taurageje, IV pėstininkų atsargos batalionas - Plungeje $\mathrm{e}^{30}$.

Tačiau Lietuvos kariuomenès vadovybė ir toliau turèjo stebėti „lenkiškąji veiksnị“. Nors Lenkijos problemų segmente plečkaitininkų teroristiniai veiksmai jau buvo nuslopę, slaptos arba neoficialios Lietuvos derybos su Lenkija, trukusios nuo 1933 iki 1938 m., dèl savo netolygumo ir kartkartėmis kylančių pasienio incidentų vertẻ būti pasiruošusiems

27 Jokubauskas Vytautas. „Mažujų kariuomenių“ galia ir paramilitarizmas. Tarpukario Lietuvos atvejis, Klaipėda: Klaipėdos universitetas, 2014, p. 70.

28 Žalys Vytautas. Lietuvos diplomatinès tarnybos ir kariuomenès vadovybès sąveika įtvirtinant Lietuvos valstybingumą 1923-1938 metais, Lietuvos nepriklausomybei - 80. Straipsnių rinkinys, Vilnius: Generolo Jono Žemaičio Lietuvos karo akademija, 1999, p. 66.

29 Kasparavičius Algimantas. Lietuvos kariuomenė Maskvos politinèse ir diplomatinèse spekuliacijose (1920-1936), Lietuvos nepriklausomybei - 80. Straipsniu rinkinys, Vilnius, 1999, p. 37.

30 Jokubauskas Vytautas. „Mažuju kariuomeniu““ galia ir paramilitarizmas. Tarpukario Lietuvos atvejis, Klaipèda, 2014, p. 68. 
dvišalių santykių paaštrèjimui ar net ir galimam konfliktui ${ }^{31}$. Dèl visų šių išvardytų priežasčių pasienio lenkiškai kalbančių gyventojų nusiteikimas, lojalumas ir apskritai jų situacijos tyrimai buvo svarbūs kariuomenès vadovybei.

Trakų (Kaišiadorių) apskrities karo komendantas išsiuntė anketą asmenims, iš kurių tikejjosi gauti atsakingai surinktą, patikimą informaciją. Respondentai $\mathfrak{i}$ klausimus atsake iš eilès pagal klausimyno skirsnius, tad pateikdami respondentų atsakymus jo numeracijos nekartosime - tai bus matyti iš atsakymų turinio ir klausimyne nurodyto eiliškumo. Atsakiusius suskirsteme pagal užsièmimą ir profesijas - paštininkai, kunigai, mokytojai, mokyklų inspektoriai, policijos pareigūnai, kitų profesijų atstovai. Atskirai pateiksime medžiagą apie tarnavusių Lietuvos kariuomenèje lenkų nuotaikas.

Kadangi visi atsakymai išsaugoti Lietuvos centrinio valstybès archyvo Trakų apskrities karo komendanto 500 fondo vienintelëje byloje (Nr. 406), išnašose žymėsime tik jos lapų numerius, visos metrikos nebekartodami, o dokumento pavadinimai (kas ir kada atsako) bus pateikti tekste.

Atsakymuose palikome nemažai citatų - kad geriau būtų galima pajusti to laikotarpio dvasią, tačiau dèl per didelès pasakojimų apimties tekstus trumpinome.

\section{ATSAKYMAI I ANKETOS KLAUSIMUS SPAUDOS PRENUMERATA PAGAL KALBAS}

Duomenys buvo gauti iš pašto viršininkų, tad ir prie atsakymų yra jų pastabų apie bendras gyventojų nuotaikas. $1933 \mathrm{~m}$. gruodžio 14 d. Kaišiadoriu pašto viršininkas gavo žinių iš Aukštadvario pašto viršininko apie kiekvieno kaimo, kurị aptarnaudavo šis paštas, o ne viso Aukštadvario valsčiaus lietuviškai arba lenkiškai kalbančius ir lietuviškus arba lenkiškus laikraščius skaitančius gyventojus.

Pavyzdžiui, Akmenų kaime lietuviškai kalbëjo 1, lenkiškai - 11, lietuviškus laikraščius skaite - 1 , lenkiškus - nè vienas. Alešiškès kaime lietu-

31 Žepkaitè Regina. Diplomatija imperializmo tarnyboje. Lietuvos ir Lenkijos santykiai 1919-1939 m., Vilnius, 1980, p. 224-250. 
viškai kalbejjo 6, lietuvių kalba laikraščius skaitė 9, lenkiškai kalbejo net 22, o skaite lenkiškus laikraščius tik 2, ir t. t. Dažniausiai pažymima, kad lenkiškai skaito tik pavieniai žmonès net, pavyzdžiui, Gudžionių kaime, kur lietuviškai kalbejjo 4, o lenkiškai - 30 žmonių, lietuviškus leidinius skaitė 7, o lenkiškus - vos vienas. Pašto viršininkas prirašè: „Ši apylinkè bene bus iš visos Trakų apskrities daugiausia sulenkejusi. “"

Apibendrinant visuose apskrities paštuose gaunamą spaudą paminèta, kad 1934 m. Žaslių paštas gavo 434 lietuviškus, 38 lenkiškus ir 6 kitus leidinius. Tame pat Žaslių valsčiuje buvęs Gegužinės paštas gavo 189 lietuviškus ir 17 lenkiškų, Paparčių paštas - 98 lietuviškus ir 2 lenkiškus, Žaslių geležinkelio stoties paštas - 88 lietuviškus, 4 lenkiškus ir 2 kitus laikraščius. Apskrities centre - Kaišiadoryse - buvo gauti net 795 lietuviškų, 38 lenkiškų ir 2 kitų laikraščių egzemplioriai. Net pačiame pasienyje - Dusmenyse - buvo prenumeruojamas net 151 lietuviškas laikraštis ir 9 lenkiški. Daugiausia lenkiškų laikraščių buvo užsisakoma Vievyje net 73, tačiau ir čia dominavo lietuviška spauda - 492 egzemplioriai ${ }^{33}$.

Onuškio valsčiaus kaimai pagal kalbų pasiskirstymą suskirstyti procentais, tačiau dèl duomenų tikslumo kyla abejonių, nes apibendrinimas nepasirašytas (galima spèti, kad pašto tarnautojo), taip pat neaišku, kuo remiantis jis buvo padarytas. Anot anonimo, gyventojai kalba: Aleksandravos kaime - 100 proc. lenkiškai, užsako 1 lenkišką laikraštį. Alekseikos kaime - 50 proc. lietuviškai ir 50 proc. lenkiškai, užsakomas 1 lenkiškas laikraštis. Arlaučiznos kaime - 50 proc. lietuviškai ir 50 proc. lenkiškai, užsakomas 1 lietuviškas laikraštis, Dembinos kaime - 100 proc. lenkiškai, bet užsakomi 4 lietuviški ir 6 lenkiški laikraščiai, Gudakiemio kaime - 100 proc. lietuviškai, užsakomas 21 lietuviškas laikraštis.

Onuškio valsčiuje kaip visiškai lietuviški nurodomi Bičiūnų, Daugeliškių, Grendavės, Gruožninkų, Panošiškių, Samninkų, Smalių, Spenglininkų, Taučionių, Žuklijų ir kai kurie kiti kaimai ir viensėdžiai. Netgi Tolkuškių dvaro gyvenvietė nurodoma kaip visiškai lietuviška, o Jankavičių dvaras (kuris priklausė Lietuvos Nepriklausomybės Akto signatarui Donatui Malinauskui ir jo šeimai) - 100 proc. kalbantis lenkiškai, bet gaunantis 4 lietuviškus ir 1 lenkišką laikraštị, 2 laikraščius kitomis

3219331214 Aukštadvario pašto viršininko raštas Kaišiadorių pašto viršininkui. LCVA, f. 500, ap. 1., b. 406, 1. 423.

33 Ten pat, 1. 415 . 
kalbomis, Lauzgonių kaime kalbama 100 proc. lenkiškai, bet užsisako 4 lietuviškus laikraščius, Tolkiškių kaime 95 proc. gyventojų kalba lenkiškai, tačiau neužsisako nè vieno lenkiško laikraščio, 5 proc. - lietuviškai, o prenumeruoja 7 lietuviškus laikraščius ${ }^{34}$.

Semeliškių valsčiaus pašto viršininkas $1933 \mathrm{~m}$. gruodžio $13 \mathrm{~d}$. parašè Kaišiadorių pašto viršininkui, jog valsčiaus gyventojai kalba lietuviškai, lenkiškai, gudiškai ir kitomis kalbomis. Duomenis parengè remdamasis „savo patyrimu, seniūnų nurodymais ir dalinomès vietos valsč. valdybos suteiktomis žiniomis“. Pastaboje pažymèjo, jog dagiau lenkiškai kalbama kaimuose arčiau administracinès linijos, bet „iš kalbančių lenkiškai tik labai maža dalis, visam valsčiuj gal tik apie 20, gyventojų yra grynai lenkiškos orientacijos ir skaito save lenkais, o šiaip visi kiti, nors ir nemoka lietuvių kalbos, skaito save lietuviais" ${ }^{\text {“35 }}$.

Semeliškių valsčiaus kaimai pagal minètų kalbų vartojimą apibūdinti taip: Aleksandrauka - 100 proc. kalba „kitomis“ kalbomis (ne lietuvių, ne lenkų ir ne gudų); Antakalnis - 1 proc. gyventojų kalba lietuviškai, 99 proc. - gudiškai; Antanava - 40 proc. lietuviškai, 60 proc. - lenkiškai; Bagdanoniai - 3 proc. lietuviškai, 2 proc. - lenkiškai, 95 proc. - gudiškai, užsakomas 1 laikraštis lenkų kalba; Budziliai - 100 proc. kalba lietuviškai, užsakoma net 11 laikraščių lietuvių kalba; Baubonys - 100 proc. kalbama lietuviškai, užsakomi 9 lietuviški laikraščiai. Iš 125 maždaug 30 kaimų gyventojai kalba beveik vien lenkiškai (95-100 proc.), apie 40 kaimų - beveik vien lietuviškai. Semeliškių miestelyje apie 70 proc. kalba lietuviškai, 1 proc. - lenkiškai ir 29 proc. - kitomis kalbomis, prenumeruojami 82 lietuviški laikraščiai ir 1 lenkiškas ${ }^{36}$.

Žilinų pašto agentūros (įeinančio į Onuškio valsčių) vedèjas V. Čenkus nenurodo gyventojų tautybių ir pateikia tik prenumeruojamų lietuviškų ir lenkiškų laikraščių skaičių: Žilinuose užsakoma 20 laikraščių lietuvių kalba, lenkiško - nè vieno; Norvidiškių dvare - 2 lietuviški, 1 lenkiškas; Puodžių kaime - 30 lietuviškų; Voniškių kaime - 4 lenkiški; Kareivonyse -6 lietuviški ir 1 prancūziškas žurnalas. Iš viso lietuviškų

\footnotetext{
34 Onuškio valsčiaus kaimų sąrašas. Ten pat, 1. 424.

35 Semeliškių pašto viršininko 19331213 raštas Kaišiadorių pašto viršininkui. Ten pat, 1. 426 .

36 Ten pat, 1. 426-428.
} 
laikraščių - 174 egzemplioriai, lenkiškų - $12^{37}$.

Dusmenų pašto agentūros (kuri taip pat įejo i Onuškio valsčiaus teritoriją) vedèjas S. Čenkus 1933 m. gruodžio 11 d. pateikè ne tik skaičius, bet ir prenumeruojamų leidinių - dažnai pavienių dienraščių, bet dažniausiai savaitraščių - pavadinimus. Dusmenyse buvo užsakomi 23 lietuviški ir 1 lenkiškas laikraštis („Chata Rodzinna“), Petrauskų kaime (kur gyveno ir Onuškio valsčiaus viršaitis Antanas Petrauskas - žymiųjų muzikų Kipro ir Miko Petrauskų brolis) - 8 lietuviški (tarp jų dienraščiai „Lietuvos aidas“ (1) ir „Dienos naujienos“ (1), 3 savaitraščiai „Mūsų rytojus" ir t. t.). Dusmenų pašto aptarnaujamoje teritorijoje, kuri apémè 28 gyvenvietes, buvo prenumeruojamas 151 lietuviškas leidinys ir tik 6 lenkiški ${ }^{38}$.

Vievio apylinkių duomenys taip pat apytikriai, tai anonimiškai parašytame rašte nurodyta kaip pastaba. Iš viso išvardinta 18 konkrečių gyvenviečių ir susumuotos „kitos vietos“. Nurodyta, jog Vievio miestelyje užsakomi 56 lietuviški ir 3 lenkiški laikraščiai, o kalbama 70 proc. lietuviškai, 30 proc. - lenkiškai. Abromiškių kaime užsakyti 4 lietuviški laikraščiai, 99 proc. gyventojų kalba lietuviškai, 1 proc. - lenkiškai. Abromiškių dvare skaitomi 4 lenkiški laikraščiai, 99 proc. kalbama lenkiškai, 1 proc. - lietuviškai (tai tarsi patvirtina teigini, kad kaimuose kalbama lietuviškai, o dvaruose - lenkiškai). Vievininkų kaime užsakomi 6 lietuviški laikraščiai, kalbama 30 proc. lietuviškai, 70 proc. - gudiškai. Zabarija gaudavo 5 lietuviškus laikraščius, nors jos tik 20 proc. gyventojų kalbèjo lietuviškai, o likę 80 proc. - lenkiškai. Lazdynai užsakydavo 3 lietuviškus laikraščius ir 1 lenkišką, bet tik 30 proc. gyventojų kalbejjo lietuviškai, o 70 proc. - lenkiškai. Ausieniškèse lietuviškų ir lenkiškų laikraščių užsakyta po lygiai - po 5, kai 30 proc. buvo kalbama lietuviškai, 70 proc. - lenkiškai. „Kitos vietos“ apėmè Vievio apylinkes, kur buvo prenumeruojama 350 lietuviškų laikraščių ir 51 lenkiškas, o kalbama 40 proc. lietuviškai ir 60 proc. lenkiškai ${ }^{39}$.

Taigi ir lietuviškos, ir lenkiškos spaudos prenumeruota labai mažai.

37 Žilinų pašto agentūros vedèjo 19331214 raštas. Ten pat, 1. 429.

38 Dusmenų pašto agentūros vedejo 19331211 raštas. Ten pat, 1. 430.

39 Vievio apylinkių gyvenviečių sąrašas. Ten pat, 1. 432-429. 


\section{KATALIKŲ KUNIGŲ ATSAKYMAI}

Geriausiai savo parapijiečius pažinojo katalikų kunigai, todèl neatsitiktinai jų atsakymai $\mathfrak{i}$ anketos klausimus yra išsamiausi. Jie noriai dalijosi pastebejimais ir pasiūlymais.

Aukštadvario bažnyčios klebonas kun. A. Žilinskas ${ }^{40} 1933$ m. gruodžio 10 d. rašè komendantui V. Žutautui, kad anketoje pateikti klausimai jam seniai rūpejo, todèl nori apgalvotai atsakyti ir atsakymus atsiųs véliau: „Manau, kad šiame pademarklinyje Aukštadvaris užima politiniu atžvilgiu gana svarbų punktą. Kiek patyriau, kad šitą labai gerai supranta lenkuojantieji ir čia Aukštadvario apylinkejje jie tiesiog atkakliai stengiasi palaikyti lenkišką dvasią ir kalbą, ir ị lietuvius žiūri kaipo ỉ jų priešus. Labai gaila, kad mes per 15 metų nesugebejome šio krašto atlietuvinti." ${ }^{41}$

Kun. A. Žilinskas 1934 m. sausio 3 d., pateikdamas atsakymus ị anketos klausimus, teigè: „Nors matoma, kad mūsų Vyriausybè deda pastangų ir skiria lèšų atlietuvinimo darbui vykdinti, tačiau ligi šiol to vaisiai buvo gana menkučiai, priešingai, - paskutiniu laiku, jau po $15 \mathrm{~m}$. nepriklausomo gyvenimo kai kuriose sulenkejusiose vietose, k. a. Aukštadvario apylinkèje, jaučiama net kiek stipresnio lenkiškume pasistūmejjimo. Lenkuojančių šeimų jaunimas vis dar tebeskaito save susipratusiais lenkais, nors jų dauguma lietuviškai kalba. Labiausiai prie lenkiškumo traukia religinis motyvas, „matant lietuvių veikèjų nuolatinius kivirčus su dvasiškija ir Bažnyčia, ir duodamos iš lenkiškųjų bankelių lengvomis sąlygomis

\footnotetext{
40 Antanas Žilinskas (1892 m. Vilkaviškio aps., 1968 m. Kaune) - kunigas, teologijos licenciatas. Mokèsi pradinèje mokykloje ir progimnazijoje. Baigè kunigų seminariją Seinuose. Seinų, Vilkaviškio vyskupijų kunigas. Vikaravo Griškabūdyje - globojo didelę „Pavasario“ kuopą, vikaras Marijampoleje. 1928-1935 m. kunigavo Aukštadvaryje. Studijavo Romoje. Grịžęs nuo 1939 m. vẻl dirbo Griškabūdyje. 1941 m. išsikèlè ị Alytų. 1949 m. sovietų ištremtas ị Sibirą. Grịžo 1955 m. ir dirbo kaip altarista. Nuo 1965 m. altarista Rumbonyse, po metų klebonauja. Nuo 1958 m. gyveno Karmèlavoje, Kauno dekanas. 41 Kun. A. Žilinsko 19331210 laiškas plk. V. Žutautui. LCVA, f. 500, ap. 1, b. 406, 1. 436.
} 
paskolos, ypač šiuo ekonominio krizio metu, turi daug pasisekimo.“42

Aukštadvario apylinkèse, pasak klebono, du trečdaliai gyventojų „lenkuojantys“. Oficialiai tik drąsesnieji „užsirašo“ kaip lenkai, kurie „iš lietuvių jokios pagalbos nereikalingi. Daugelis dèl tam tikrų išskaičiavimų nors ir rašosi lietuviais, bet dvasioj jaučiasi gal dar stipresniais lenkais už pirmuosius“. Vietiniai, „tikrieji lietuviai“, su už pasienio linijos gyvenančiais ryšių beveik nepalaiko. $\mathrm{O}$ „lenkuojantys“ stengiasi ten apsilankyti bent kartą per metus, pasimatyti su giminėmis, vyksta ir tik dẻl kontrabandos („manufaktūra“ ten pigesnè, bet apskritai „gyvenimas pas mus esąs lengvesnis"). Klebono nuomone, tinkamiausias motyvas patraukti „lenkuojančiuosius“ - „artimas su jais susidraugavimas, pažinimas jų vargingos padeties ir nuoširdus, tik ne žodžiais, bet darbais, stengimasis jiems padèti. Ivvairūs mokesčiai, gyventojų prispaudimai (presijos), nuostolių mokèjimai, kelių taisymai, rekvizicijos, net ir trèmimai tikslo nepasiekia. Bet koki iš mūsų pusès spaudimai dar labiau lenkiškume sustiprina, nes uždedamas pinigines pabaudas sumoka lenkų bankeliai“"43.

Rašydamas apie savivaldybès ịstaigu įtaką, kun. A. Žilinskas nurodo, kad „išrinktasis ị savivaldybę lenkiškasis elementas ant tiek parodo valstybinio nusistatymo, kiek mato asmeninès naudos. Gudresnieji gi tiek valstybiniai nusistatę, kiek jie gali patarnauti lenkuojančių interesams. Dar kartą pastebiu, kad veidmainiavimas šiame krašte taip yra didelis, kad tiesiog reikia stebètis ir nuogąstauti. Šiuo reikalu reikia imtis pagrindinių auklejjančių priemonių. Prikalbinejjimas ar presija išduodant pasus maža reikšmès turi. Daugelis gana stiprių dvasioje lenkų sutinka pasuose registruotis lietuviais dèl tam tikrų išskaičiavimų, nes sako: „kitaip su pagonimis nesugyvensi“. Šio veidmainiavimo išmoko iš čia atvykusių ịvairių persimetėlių lietuvių veikèjų. Kol ị ṣ̌ kraštą bus siunčiami užimti atsakomingas vietas asmens be visapusiško išauklèjimo ir kultūringo

42 Kun. A. Žilinsko pabrèžti „lietuvių veikèjų nuolatiniai kivirčai su dvasiškija ir Bažnyčia“ yra kitos temos ir kitų interesų dalis (tai - Vyriausybės ir Bažnyčios nesutarimai dèl civilinès metrikacijos įvedimo), todèl jų šiame straipsnyje nenagrinèsime, tik atkreipsime dèmeși, kad kun. A. Žilinskas labai aktyviai dalyvavo šioje „kovoje“ tiek tarnaudamas parapijos klebonu, tiek Aukštadvario vidurinèje mokykloje dèstydamas tikybą (pavyzdžiui, mokiniai skautai susilaukdavo jo griežto pabarimo, o katalikiškų organizacijų nariai palaikymo ir geresnių pažymių - aut. pastaba).

43 Kun. A. Žilinsko 19340103 atsakymas ị anketą. LCVA, f. 500, ap. 1, b. 406, 1. 433. 
paruošimo atlietuvinimo darbui dirbti, tol visokios instrukcijos ir geriausi nurodymai, kad ir administracijos organams, paliks be vertès“44.

Anot kun. A. Žilinsko, „Šaulių sąjungai čia pasienyje bendrai sąlygos veikti yra daug geresnès, negu kurioms kitoms organizacijoms. Teoretiškai imant, jos veikimas išplèstas beveik visame pasienyje ir turi skyrius, rodos, kiekviename bažnytkaimy“. I šaulius užsirašę valdininkai ir beveik visi mokytojai, „net pradžios mokyklų inspektorius“. „Lenkuojantys“ noriau ị šaulius rašosi, „kad be leidimo galètų nešiotis ginklą ir užejus norui - pašaudyti“. Aukštadvario šauliai 1933 m. subūrè orkestrą ir per gavėnią grịžtantiems iš bažnyčios žmonėms „viešai demonstravo“. Be to, šaulių rengiami vakarai „pasižymi fokstrotiniais šokiais ligi ankstybo ryto ir bufetais su svaigalais“. Nors Šaulių sąjunga vienintelè turi geras sąlygas veikti, bet dèl savo vadų netinkamumo save kompromituoja.

Iš kitų organizacijų, anot klebono, šiame krašte sėkmingiausios katalikiškos organizacijos - pavasarininkai, KVC (Katalikų veikimo centras) skyriai ir „angelaičiai“. Šios organizacijos galètų atlikti daug lietuvinimo darbo, jei turètų tokių privilegijų kaip šauliai ir kitos tautinès organizacijos. Lietuvinimo darbas prastas, nes „šio krašto inteligentija nuo katalikiško visuomeninio veikimo šalinasi tarsi kokios pavietrès“45.

Lenkiškų mokyklų Aukštadvario apylinkèse visai nèra ${ }^{46}$. Lenkiškumas palaikomas per agentus ir spaudą. Labiausiai paplitęs laikraštis - „Chata Rodzinna“, kuris eina per rankas. Taip pat veikia lenkiški knygynèliai, lenkiškos knygos plinta net iš vieno garsaus dvaro, kurio savininkai - net Aukštadvario skautų globejjai ${ }^{47}$.

\footnotetext{
44 Ten pat. 1. 433-434.

45 Ten pat. 1. 434.

46 Čia kun. A. Žilinskas kalba apie 1934 m. situaciją, nes 1926 m. valdžioje atsidūrus valstiečiams liaudininkams su koalicijoje esančiais socialdemokratais ir lenkų frakcija, Trakų (Kaišiadorių) apskrityje per trumpą laiką buvo ịkurta apie 10 lenkiškų mokyklų, kurios vèliau, atėjus į valdžią tautininkams, buvo palaipsniui uždarytos.

47 Greičiausiai kun. A. Žilinskas turi omenyje Aukštadvario dvarą, kurio savininkas buvo daktaras Vladas Mongirdas, aktyvus ne tik Aukštadvario valsčiaus, bet ir visos apskrities veikejjas. Tačiau dr. V. Mongirdas šiose apylinkèse dar carizmo laikais buvo žinomas lietuviškų knygų platintojas ir lietuvių kalbos aktyviausias gynėjas. Todėl užuomina apie "garsaus dvaro“ savininką gali būti konfrontacijos tarp Bažnyčios ir aktyviausių esamos Vyriausybės politikos šalininkų ženklas.
} 
Pasak kun. A. Žilinsko, yra mažai sąžiningai dirbančių mokytojų, daugelis jų ir mokyklų inspektorius - nepraktikuojantys katalikai. Jie vaikams dalija maldaknyges, nors žmonès ịpratę, kad tai darytų kunigas. Labiau pasitikima mokytojomis, tačiau mégstami ir tvarkingi mokytojai vyrai. Kunigas pageidavo, kad darbui būtų siunčiami „turintys cenzą“, pagyvenę, taktiški mokytojai, praktikuojantys katalikai.

Kun. A. Žilinskas teigia, kad lietuvinti per Bažnyčią nelengva, nes dauguma valdininkų ir lietuvių veikejų „yra antikatalikiško nusistatymo ir neturèdami kuo pasirodyti patriotais darbuotojais, tuojau pradeda ginčus su kunigais reikalaudami tuojau panaikinti lenkiškąsias pamaldas, kurios jiems (lenkams) yra laikomos kas trečias sekmadienis“. Pavyzdys - Aukštadvaryje, lenkams skirtą sekmadieni "pasisamdę kokị nepilnaprotị゙, bažnyčioje sukèlè triukšmą, ji palaikè šauliai, kilo peštynès. Gynę savo teises 13 žmonių buvo nubausti administracinèmis 200-400 Lt baudomis, bet jas sumokèjo „lenkų bankelis“. Panašus triukšmas organizuotas ir Onuškyje ${ }^{48}$, Pivašiūnuose. Pasak kunigo, pafrontèje visi kunigai yra lietuviai patriotai ir lietuvinimo darbą dirba jau seniai, bet remdamiesi evoliucijos principais, o patriotai mano per kelias dienas padaryti revoliuciją ${ }^{49}$.

48 Vargu ar visada toks triukšmas dèl kalbos bažnyčiose buvo specialiai organizuojamas. Pavyzdžiui, 1929 m. triukšmą Onuškio bažnyčioje kèlè Smalių gyventojas A. B., psichikos ligonis, pabėgęs iš „pamišèlių namų“, neklausęs netgi Onuškio policijos nuovados viršininko drausminimo. Parapijiečius, kurie norejo ji išvaryti iš bažnyčios, puldavo mušti, kandžioti, todèl niekas nedrịso jo liesti. Onuškio nuovados viršininkas Taraila 19290910 aiškino apskrities policijos vadui, kad A. B. vietos gyventojams nepavojingas, tačiau be galo nekenčia lenkų kalbos, ypač susierzina, kai išgirsta kalbant lenkiškai valdininkus ar dvasininkus. A. B. istorija 19290910 pasiekẻ netgi VRM Piliečių apsaugos departamentą, kurio buvo klausiama, ką tokiu atveju daryti. Trakų apskrities viršininkas A. Steikūnas nuovados viršininkui paaiškino, kad nepadorių riksmų, triukšmo maldos namuose reikia neleisti, tad įstaigų administracija turi teisę kreiptis į policiją. Kilus nesusipratimų su A. B., administracijai reikia kviesti policiją, pradèti bylą ir perduoti ją teismui. Plačiau žr.: LCVA, f. 409, ap.1, b. 2, 1. 100-105.

49 Kun. A. Žilinsko $1934 \mathrm{~m}$. sausio 3 d. atsakymai į Trakų apskrities komendanto anketos klausimus. LCVA, f. 500, ap. 1, b. 406, 1. 433-435. 
Gegužès bažnyčios Žaslių valsčiuje kun. S. Pupaleigis ${ }^{50} 1933$ m. gruodžio 19 d. pateikè pastabas, kad pagrindiniai lenkintojai anksčiau buvo Bažnyčia ir dvaras. Dabar dvaras nebeturi tos reikšmès, o Bažnyčia Lenkijos okupuotame Vilniaus krašte su „endekais“ ir "davatkų legionais“ ir toliau lenkina vietos lietuvius. Jie neskiria tautybès nuo religijos (t. y. tapatina lenkiškumą ir katalikybę), baugina vilniečius lietuviais pagonimis. Populiarios tik religinès organizacijos (akcentuojama pavasarininkų veikla), o ,šauliams, tautininkams ir aplamai politiškoms organizacijoms [Lietuvos] rytai nepritare ir dar ilgai nepritars". Anot kun. S. Pupaleigio, „atlietuvinimui“ labiausiai kenkia Bažnyčios ir valstybès konfliktas, o lenkai tuo naudojasi.

Mokykla gali padèti lietuvinti tik tada, jeigu bus katalikiška. Pasak jo, mokytojos „atlietuvino“ kai kuriuos lenkiškus kaimus vadovaudamos gegužinèms pamaldoms. „Iš karto vyresnieji rinkosi skyrium lenkiškai melstis, bet paskui, jaunesniụjų apleisti, suejjo vienon vieton. Neužmirškim, kad mes visi rytiečiai turime savyje daug misticizmo, kuris nesuprantamas ir neįvertinamas atejjusiųjų pas mus darbuotis $<\ldots>$ Mokykloje ypač reiktų kreipti dèmesị ị dainas ir istoriją, nes rytiečiai yra dainiai ir dideli mègejjai pasakų, padavimų apie senovę ir jos milžinus."

Nemažą vaidmeni galètų suvaidinti valdininkai, bet jie turi būti geri, sąžiningi, teisingi, mokèti susikalbèti lenkiškai, nes yra vyresnių žmonių, kurie be jokios piktos valios tiesiog nemoka lietuviškai. Pasitaiko, kad vietiniai ir geri žmogeliai kursto, bet jie tai daro ne iš idejos, o už pinigus. Juos reikia sudrausti, bet tai turi daryti atvykę iš kitur, kad vietiniai nebijotų savụjų ${ }^{51}$.

50 Pupaleigis Stanislovas (1887 m. Eiriogalos k., Kaišiadorių r., 1967 m. Papilè) - katalikų kunigas, pedagogas. Mokèsi Žasliuose ir Trakuose, $1910 \mathrm{~m}$. baigė Peterburgo dvasinę seminariją, vikaravo Peterburge, I pasaulinio karo metais gyveno Tomske, bendravo su K. Būga. Grįžęs 1920 m. ị Lietuvą, studijavo lituanistiką Aukštuosiuose kursuose, dirbo Aukštadvario gimnazijos direktoriumi, vadovavo Aukštadvario dvimečiams mokytojų kursams, ịsteige Šaulių sąjungos skyrių. Nuo $1928 \mathrm{~m}$. - Gegužinès klebonas (dab. Kaišiadorių r.), čia pastatè bažnyčią. Nuo 1934 m. - Kretingos pranciškonų gimnazijos direktorius, mokytojas, nuo 1945 m. gyveno Žarènuose, paskirtas Plungès klebonu, čia išprovokuotas sovietinio saugumo ir nuteistas skyrus $10 \mathrm{~m}$. lagerio, bausmę atliko Abezio lageryje, paleistas 1954 m., paskirtas altarista ị Papilę. Mokèjo anglų, prancūzų, slavų, latvių kalbas. Šiaulių „Aušros“ muziejui perdavè kunigo archeologo J. Žiogo radinių kolekciją. Palaidotas Papilès bažnyčios šventoriuje.

51 Kun. S. Pupaleigio 19331219 laiškas. LCVA, f. 500, ap. 1, b. 406, 1. 437-438. 
Išsamiausias buvo Kernavès bažnyčios klebono kun. Nikodemo Švogžlio $^{52}$ atsakymas, rašytas „slaptai, asmeniškai“, siekiant išaiškinti „teisingą pafrontès filosofiją“. Pažymètina, kad tai - labai emocingi atsakymai, kartais jausmingi ir „sutirštinti“, dramatizuoti. Susirūpinęs kunigas rašè:

„Tikroji padètis labai pavojinga ir baisi. Visa vietinė masė yra lenku orientacijos: Kernavè-Kazokiškis-Vievis-Semeliškès-Aukštadvaris-Onuškis. Arba atgal: Kernavè-Širvintai-Giedraičiai-Dubingiai (lenkystès centras)“, o lietuvių administracija labai apsirinka manydama, kad lenkų pafrontès padètis yra pakenčiama, jeigu lietuviai „sulošia“"53 per metus kelis vakarus, padaro vasaros metu kelias gegužines, o „lenkininkai“ šiek tiek jau pakalba lietuviškai, nes yra ramūs ir netriukšmauja. Iš viso to nereikia manyti, kad pafrontė jau sulietuvejo arba nuoširdžiai lietuveja. Tai yra tik paviršutinis reiškinys, kuriam vadovauja daugiausiai seksualinis motyvas: nori bernai ir mergos lenkininkai pašokti - tai ir dalyvauja lietuvių pramogose. „Nors ir pakalba truputị lietuviškai - bet viduje vis tiek jie pikti lenkininkai. 1. kurie visai nekalba lietuviškai - tie mažesni ir švelnesni lenkai; 2. kurie truputi pakalba - jie pikti lenkai:

a) jie tai kerštaudami lietuviams truputị pramoksta, kad galètų gaudy$\mathrm{ti}^{54}$ lietuvių kalbą;

b) jie gudrūs ir veidmainingi lenkininkai - keliais lietuviškais žodžiais jie nori paslèpti savo lenkiškumą.

Tai baisiai sukta psichologija... Ją reikia suprasti..."

Kunigas pažymi, kad pafrontès lietuviškąji elementą sudaro ne vieti-

52 Švogžlys Nikodemas-Milžinas (1899 m. Trebučių k., Švenčionių apskr., 1985 m. Vievis, palaidotas Kernavės bažnyčios šventoriuje) - kunigas, visuomenės veikèjas, publicistas, istorikas. Vos gimus Nikodemui, šeima išvyko ị Rygą uždarbiauti, o 1915 m. grịžo ị Trebučius. 1918-1921 m. mokèsi Vilniaus dvasineje seminarijoje. $1918 \mathrm{~m}$. debiutavo spaudoje eilèraščiu „Gyvuok, Tẻvyne“. Iš trečiojo seminarijos kurso buvo pašalintas. $1921 \mathrm{~m}$. ịstojo ị Žemaičių dvasinę seminariją Kaune. 1922 m. perejo ị Lietuvos universiteto Teologijos-filosofijos fakulteto Teologijos skyrių ir 1925 m. jị baigè. $1925 \mathrm{~m}$. birželio 14 d. įšventintas kunigu. 1925-1927 m. - Molètų vikaras ir progimnazijos kapelionas. 1927-1930 m. - Kaišiadorių vikaras, kurijos notaras ir mokyklų kapelionas. 1930-1934 m. Kernavès klebonas, 1934-1939 m. Gegužinès klebonas, 1939-1953 m. Onuškio klebonas, 1953-1954 m. Kauno Igulos bažnyčios klebonas, 1954-1968 m. Bijutiškio, Kruonio, Kazokiškių, Paparčių, 1968-1979 m. Kernavès klebonas, 1979 m. Musninkų klebonas. Nuo 1979 m. rugpjūčio vidurio skiriamas Vievio rezidentu.

53 Surengia.

54 Tai yra, kad susigaudytų, kas kalbama lietuviškai (aut. past.). 
niai, čia seniai gyvenantys piliečiai, o imigrantai ir kolonistai arba administracijos valdininkai ir tarnautojai. Kaip pavyzdys minima Kernavé: visa apylinkė lenkiška, o lietuviškąji elementą sudaro apie 20 žmonių kunigas, du mokytojai, aštuoni policininkai ir kelios policininkų žmonos, pasienio policijos rajono viršininkas ir vachmistras, eigulys, vargonininkas ir siuvejjas: „Bet jie visi ne vietiniai. Jie atejūnai. Jie čionai svetimi ir laikini. Priešui ịsiveržus - jie būtinai evakuotų[si]. Vietoj nepasiliktų. Taigi priešui įsiveržus tokioj Kernavèj jau nebūtų nẻ vieno lietuvio. Visi būtų lenkininkai. Priešas visiškai laimètų."

Kun. N. Švogžlys pabrèžia, kad būtent šie 20 lietuvių rengia ir lietuviškus vakarus, ir gegužines, ir sporto renginius, ir paskaitas. Bet paskaitu klausoma, nes jos beveik visada skaitomos lenkų kalba, paįvairinamos idomiais paveikslais, po jų dažniausiai vyksta šokiai. Jei to nebūtų - $\mathfrak{i}$ paskaitas neitų.

Panaši padėtis ir Kazokiškèse, Vievyje. Bet Kazokiškèse lietuvių dar mažiau, negu Kernaveje: kunigas, mokytoja, trys kunigo tarnai, pasienio policija - visi atejuūnai, ne vietiniai. Labiau lietuvybė reiškiasi Vievyje, bet ten ji irgi laikina: „Ji pasireiškia tik todèl, kad čia yra Lietuvos Valstybès režimas. Jeigu ịsiveržtų priešai lenkai - lietuvybè pasitrauktų. "Lietuviškus vakarus Vievyje rengia atvykę lietuviai - mokytojai, valsčiaus sekretoriai, policininkai, „priešui ịsiveržiant - visi jie turès bègti“. „Svarbiau būtų vietinius lenkininkus patraukti, darban ịkinkyti ir tuo pačiu sulietuvinti. O taip nèra."

Apibūdindamas gretimą miestelį, kunigas pažymi, kad „Vievis nèra lietuviškas, nors dabar tenai ir pasireiškia lietuvių aktai: vakarai, gegužinès, Vilniaus Diena, šauliai, skautai... Visa tai kuria ne vietiniai (be labai mažų ir nežymių išimčių) - bet laikini atejjūnai lietuviai (pav. kap. Žmuidinavičius, sekretorius Janutènas, policininkai ir kiti). Jie turès evakuotis. Plačiai rašau - noriu išaiškinti teisingą pafrontės filosofiją. Tikroji dabartinè padètis yra dar pavojinga ir kalba priešo naudai."

Kokie santykiai su kita pasienio puse? Kunigo akimis, jei policija griežtesné ir piniginès bausmés didelès - santykiai nutrūksta, jei švelnesnè - santykiai pagyvejja. Jis pažymi, kad lenkai neužsiima agitacija, nes materialinè padètis Lenkijoje trigubai blogesnè, o lietuviai lenkų kalbos nepersekioja. Kadangi Lenkija neturtinga, jos niekas ir nesiilgi. Taigi, lenkai iš Vilniaus neagituoja, nes neturi argumentų. „Yra kitos rū- 
šies - vidujinè agitacija. Lenkininkus agituoja: lenkų ponai, dvarininkai, šlèktos, lenkų pataikūnai, sąmoningesni lenkininkai ir t. t. Labiausiai tai senos lenkininkès mergos ir moterys. Šitos agitacijos motyvas - nepasiduoti lietuviams, išlaikyti lenkų kalbą, poterius, giedojimą lenkiška forma.“ Pasak kunigo, šią agitaciją vykdo „netikę, girtuokliai, ištvirkèliai, ateistai, nemandagèliai, mušeikos ir pan. vietos liet. valdininkai“, policininkai, „kurie tvirkina mergas, nelaiko penktadieni pasninko, nekalba poterių“. Vietiniai visus juos vadina „litwini pogani“"55 ir yra pasiryžę nepasiduoti jų kalbai ir valstybei; kerštingas pavydas (mat lietuviai gauna algas, turi daugiau pinigu, yra gražiau apsirengę, dažniau palèbauja, o tai kelia pavydą). „Reikia nedemonstruoti savo išgalių, reikia nesiskirti, reikia susilieti su lenkininkų mase ir ją perskrosti lietuvybe. Lenkininkai sako: mes mokame mokesčius už žemę, o lietuviai (policija, mokytojai, valsčiaus valdininkai, viršininkai) gauna iš mūsų pinigų dideles algas ir ulioja."

Rašydamas apie pasienio zonoje paplitusi pelningą kontrabandos gabenimą, kunigas N. Švogžlys konstatuoja: „Lietuviai neša (tai galima, tik reikia užsiregistruoti) lenkų pusėn: tabokas, druska, cukrus, sacharinas, pipirai, naminis tabokas.“ Kaip pavyzdị nurodo mokytoją Simą Bakšĭ, kuris mokytojaudamas Musninkų valsčiuje per 5 metus uždirbo apie $30000 \mathrm{Lt}$ (vèliau jis dirbo Vievio valsčiuje). Bet kai kas gabendamas kontrabandą ir nukentejjo, pakliuvęs lenkų pasieniečiams, gavo baudų ir kalejjimo. Kodèl neša kontrabandą per sieną? Pirmiausia, - dèl pinigų, antra - dèl „tuščio ịdomumo“, „lenkų honoro“ - mat jaunimas didžiuojasi, kad nuejo, kad atsinešè ir turi, dèl nuotykių, nes uždraustas vaisius masina (pavyzdžiui, susilažina, ar pagaus)“, kiti eina dèl reikalų (dokumentų, metrikų, susitikti su giminèmis ir t. t.), o dalis tuo užsiima kaip profesionalai kontrabandininkai arba vedliai per sieną.

Anot kunigo, pereiti sieną Lietuvos gyventojams naudinga, nes „nuëję Vilniun pamato lenkų skurdą“, „, susitinka savuosius, kurie baisiai dejuoja“, „atèję iš Vilniaus čionai - pamato Lietuvos rojų ir grị̌z̨ Vilniun skleidžia lietuvišką gerovę, o kartu ir simpatiją Lietuvai“, „kas nueina Vilniun - ten jiems niekas nepatinka (tik patinka žmonių pamaldumas, religingumas, nes bažnyčios - pilnos žmonių, žmonès tenai pripažista Dievą“. „Pas mus trigubai geriau“, sako atbėgèliai iš Vilniaus: daugiau pinigų, daugiau dar-

55 Liet. „pagonys lietuviai“. 
bo, nėra „lietuviškos presijos“, niekas neseka, neregistruoja, neagituoja, nekankina, o Vilniuje visa tai vyksta. Lenkijoje mokesčiu anarchija: nežinai, kiek mokèti, net nèra nustatyta, kada mokèti, bet nuolat reikalauja už kažką mokèti, nes už viską ima, tik neaišku, kam mokèti ir t. t.

Apžvelgdamas valdiškų i̇staigų ịtaką kunigas pažymi: „Lenkininkai labai trokšta garbès. Išsigimęs ir pagedęs kraujas instinktyviai save gina ir išaukštintas, pagerbtas - ištikimai tarnauja, darosi patriotu. Išrinkti savivaldybèn - lenkininkai virsta lietuviais. Ginčų nekelia. Palaiko lietuviškus interesus. Galvoja ir dirba valstybiškai. Tuojau išmoksta lietuviškai $<\ldots>$ Pasus ir liudymus išduodant organai neklausia: kas tu - lietuvis ar lenkas? Savaime registruoja lietuviu. Taigi, visi lenkininkai dokumentuose figūruoja lietuviais. Tai gerai:

1. Lenkininkai pripranta, kad jie lietuviai. 2. Kartais net didžiuojasi: $a$ cóž ja nie litwin, a gdzie ja mieszkam - czy nie w Litwie?56 3. Tokių šeimų vaikai turi eiti lietuvių mokyklosna."

Kunigas pastebi, kad kai pasuose visus užrašo lietuviais - žmonès apsipranta ir sutinka. Administracinès ịstaigos (valsčiaus valdžia, pasienio ir vidaus policija, klebonija) neippareigoti dirbti lietuvybės puoselëjimo darbo, o kai kas tam net kenkia:

„1. Kai viršaitis geria degtinę ir mėgsta kompanijas; 2 . sekretoriai ima kyšius ir girtauja; 3. jeigu policininkai žiaurūs ir girtauja; 4. jeigu Rajonų Viršininkai ir Nuov. Viršininkai geria; 5. jeigu klebonai yra seni ir ne psichologai.“

Todèl kunigas siūlo ị nutautèjusias vietoves skirti tobuliausius valdininkus, nes iki tol buvo atvirkščiai - i pafrontę baudžiant buvo tremiami blogiausi valdininkai. Svarbu valdininkų moralè, kad nesiųstų nemoralių. Mini, kad 1930 m. iš Kaišiadorių i pafrontę atsiunte Kelduš̌t, „kuris dešimčiai metų čia sutrukdè lietuvybę“.

Kunigo teigimu, bloga ir ministerijų politika - nusikaltusius siųsti „Sachalinan“, „Sibiran“, t. y. „Vilniaus pafrontèn“. Blogybès šaltinis - Kauno departamentai. „jie šaukia „valio už Vilnių“, bet velnią mislija“, nes nesupranta pafrontès lietuviškų reikalų, nesidomi nutautèjimu... „Adm. organai neturi jokių instrukcijų lietuvinti žmones (gal turi, bet tikrai jų nepildo), nes nematyti ir nejausti, kad ką gera lietuvybei darytų." I Kaišiadoris ir pafrontę, $\mathfrak{i}$ sulenkejjusias vietas, siūle siųsti praktikuojančius

56 Liet. „O kuo aš ne lietuvis? O kur aš gyvenu - ne Lietuvoje?“ 
katalikus, dorovingus žmones, atkelti „gryniausio kraujo“ lietuvius, išvalyti „lenkininkus gelžkeliečius“, nes elektros stotyje - rusas, urejdijoje vokietis. Kas pašto viršininkas? Reikia juos kelti ị Šiaulius, Marijampolę ir kitur, „kur gryna Lietuva“. Kunigas pastebejjo, kad lenkai anoje sienos pusejje iškèlè vietinius geležinkeliečius, policininkus ir valdininkus toliau, o atkèlè „ॄ̣ kresus“ grynus lenkus. „Reikia valyti Vilniaus parubežį. Reikia gryno kraujo lietuvių.“ Siūlo valdininkams nekalbėti lenkiškai, „nes kai kalbame lenkiškai - lenkai mato mūsų silpnybę, negerbia mūsų, negerbia Lietuvos. Kada reikalausime ir patys kalbèsime lietuviškai - lenkai pajus mūsų galybę, o galybė imponuoja, galybė ima viršų. Vilniaus pafrontei reikia lietuvių valdininkų, kurie palaikytų santykius su kunigais. Žmonès pasitiki kunigu ir klebonija“.

Rašydamas apie visuomenines organizacijas, kunigas konstatuoja, kad pafrontèje Šaulių sąjunga silpna, nes joje vyrauja tik atejūnai lietuviai, valdininkai ir tarnautojai. Vietiniai „lenkininkai“ ir paprasti kaimo bernai ị šaulius nestoja, nes „bijo neramių laikų, kai buvo neutralinè zona, kai siautè partizanai, kai buvo žudymų“. Dèl to kalta Kauno šaulių vadovybė ir apskričių rinktinès. Reikia aiškinti žmonėms, kad tai ne partizanavimas, o savo žemės gynimas. Nèra pratybų, vadų pavyzdžio. Pvz., nuo 1923 m. ị Kernavę niekas nebuvo atvykęs nei iš Kauno šaulių centro, nei iš Ukmergès rinktinès. „Lietuvybei gali daug padèti pr. mokyklų skautai, bet reikia susitarti su vyskupais - kad kunigai galètų ne trukdyti, bet remti skautų darbą. O iki šiol dar nesusitarta."

Kun. N. Švogžlio nuomone, lietuviai inteligentai nepadeda lietuvybei, nes nebendrauja su liaudies masemis, dauguma yra jų liberalių ir internacionalinių pažiūrų, be to, „visų privatus gyvenimas yra baisus“. Kaip pavyzdžius pateikia Kernavės matininką Onaitị („savo netvarkingu gyvenimu numuše lietuvybę“), buvusị Kaišiadorių mokyklų inspektorių, kuris paskui „ištremtas“ i Šrvintus, ten suviliojo buvusio mokyklų inspektoriaus žmoną, kol pagaliau juos visus tris išblaške po Lietuvą. „Jie visi baisiai papiktino lenkuojančius Širvintus; žmonès sakè: „przeklęta paganska Litva. “" ${ }^{7}$

Kunigas siūlo daugiau prisidèti valstybei ir savivaldybèms: „Reikia agitacijos. Agitacijos lašas po lašo ir akmeni pratašo. O tokioj Kernavejj nuo 1918 m. VI-16 d. niekas nebuvo - niekas nepagyrè Lietuvos. Reikia

57 Liet. „prakeikta pagoniška Lietuva“. 
suformuoti kalbėtojus. Reikia juos siųsti pafrontèn. Teagituoja. Taip daro komunistai (Rusija), daro lenkai (Ok[upuota] Lietuva), daro vokiečiai (Klaipeda). Tik lietuviai nieko nedaro. To negali daryti mokytojas, kunigas, policija. Pas lenkus Ok. Lietuvoj Švenčionių apskr. lenkų agitatoriai važinèja su kino aparatais ir rodo lenkus: prezidentą, valdžią, kariuomenę, miestus, turtus, iškilmes, sportą ir baltajjị arą. Rodo karalienę Jadvygą, Jogailą ir pan. Žmonès mato lenkų galybę, ịtiki ir lenkèja. <...> Viso to negali atlikti valsčius, mokytojas, kunigas. Reikia iš Kauno, ar iš apskrities. Vilniaus pafrontèj reikia liaudies namų su salèmis, kad galima būtų susirinkti ir lietuviškai veikti. Šv. ministerija pastatė mokyklas (Kernavė, Musninkai, Aleksandriškès) - jos visai netikę, nèra salių, netelpa žmonės. Salès geriausia statyt (pačioj pafrontèj) parapijines. Toliau - galima šaulių vardu. Mokyklos to negali. Jei mokykloj prasidès agitacija - atsiras žmonių nepasitikejjimas mokykla. Negerai. Reikia atskirų salių. Liaudies namų veikimą lietuvybès naudai - galiu žodžiu referuoti, rašyti - nusibodo.“

„Lenkininkai“ turi pafrontèje „ponų lenkiškas bibliotekas - skrajojamas“, kurios gauna knygų iš Varšuvos (nurodo, kad jų narè yra Kaišiadorių urèdo Malvico žmona). Taip pat yra liaudiškų bibliotekų, duodančių knygų kaimiečiams, o „Pochodnia“ rengia kaime vaikams eglutes ir dalina saldainius. „Lietuviai tokių lietuviškų bibliotekų neturi nei Onušky, Aukštadvary, Vievy, Kazokišky, Kernavejj, nei Musninkuos, nei Širvintuos, nei Giedraičiuos, nei Dubingiuos (lenkiškiausia Lietuvos vieta) - niekur nèra. Tokias lietuviškas bibliotekas reikia kurti prie parapijų (žinoma, tik pačioj pafrontèj), kitur - prie šaulių. “ Anot N. Švogžlio, „kaimiečiai, kurie pradeda imti knygas ir skaityti - tuojau lietuvejja <...> kaimiečiai nori knygų. Klebonas pažista visus kaimiečius. Klebonas taikys tinkamas knygas savo žinomam parapijiečiui. Pirma duos neutralaus turinio. Paskui patriotiško ir t. t.“

Kun. N. Švogžlys teigia, kad „Kernavès apylinkès mokytojai - dideli idealistai - puikiai darbuojasi. Čia reikia skirti ne už bausmę, ne nusikaltusius, ne tinginius, ne opozicionierius, ne kontrabandininkus. Čia reikia skirti gabiausius, linksmiausius, rimčiausius, uoliausius mokytojus. Nes čia Vilniaus reikalai. Dabar visi gabiausi, kurie įtinka Šv. Ministerijai, skverbiasi centran Kaunan: ten yra kinas, opera, taxi, judejimas, centras... etc. Tai ne tautiškas reiškinys. Nèra idealizmo. Vilnius nemasina. Nenori pavargti, pakentèti, pasiaukoti. Nemyli Vilniaus. Tegu Šv. Ministerija tuo 
susirūpina. Vilniaus pafrontė brangiau - negu Kaunas“.

Kunigas siūlo: „Vilniaus pafrontèn, sulenkintosna sritysna, reikia skirti tiktai vyrus mokytojus. Vyrai mokytojai: 1. išmintingesni, 2. gudresni, 3. patvaresni (daugiau gali kentėti), 4. sumanesni, 5. darbingesni, 6. drąsesni, 7. griežtesni. Vyrai mokytojai: 1. gali kalbèti (prakalbos, referatai), 2. gali organizuoti, 3. gali sportuoti, 4. gali fiziniai reaguoti, 5. gali apsiginti (kad ir kumštimi!), 6. gali veikti konspiratyviai, 7. gali suburti talkininkus. Vilniaus sulenkejusioj pafrontej moterys ir panelès mokytojos visai netinka. Jos: 1. nemoka ir negali kalbèti viešai, 2. jos bijo, 3. jos labai lepios, 4. jos užsiflirtuoja - ir tada tik žmones juokina ir demoralizuoja, 5. lenkininkai juokiasi iš panelių mokytojų, 6. lenkininkai negerbia panelių mokytojų, 7. panelès mokytojos čia labai kenksmingos: a) jos siuvasi brangius rūbus - tai mato vietos sulenkejjusios mergaitès, nori pasekti, nori panašių rūbų, bet negali nusipirkti, prašo tèvų, tèvai neturi iš ko tada visi keikia panelę mokytoją - kam gundo jų dukteris, b) panelès mokytojos siuvasi labai „moderniškus“ rūbus - su nuogybèmis - tai demoralizuoja lenkininkus (o Šv[ietimo] Ministerija neturi įstatymo, draudžiančio siūti rūbus - permatomus. Gerai, jeigu pati panelè mokytoja yra supratinga, tai ji vengs tokio papiktinimo, bet dažniausiai panelès mokytojos yra nesupratingos, ypač nesenai baigusios lietuvių mokytojų seminarijas. Tos seminarijos išleidžia koketes, modistes, pudruotas, perfumuotas flirtininkes, "paneles“ ir būsimas „poniutes“ - o ne Pavilnès vargo peles ir kankinius..."

Anot konservatyvaus ir prisibijančio modernių moteriškų rūbų eventualiai erotinio poveikio kun. N. Švogžlio, tinkamesni yra jauni mokytojai vyrai: „Bet jaunos panelès - visai netikę: 1. jos dažnai verkia, 2. jos ịsimylejję iš proto eina." Kaip pavyzdị nurodo Skirmantiškių mokytoją (Vievio valsčiuje), kuri ịsimylejo policininką - policininką iškèlè, o ji buvo išvežta ị psichiatrijos ligoninę. „O panele mokytoja išejo iš proto - Vilniaus pafrontej. Lenkininkai piktai juokiasi: to taka ichnia Litva! ${ }^{58}$ Tokia jų Lietuva... skandalas. 3. Bet ir senos - senmergés panos mokytojos netinka pavilnèn: 1. jos labai juokingos, 2. jos įsimyli jaunus kaimo bernelius ir susidaro daug pamfletų... Pafrontèj - nereikia moterų mokytojų."

Kun. N. Švogžliui imponuoja pagyvenę mokytojai vyrai. Pavyzdžiui, 1927-1930 m. gyvendamas Kaišiadoryse, jis pažinojo 50 metų mokytoją

58 Liet. „Štai kokia ta jų Lietuva“. 
Vladą Kavecką. ,Jis buvo nepaprastai naudingas: 1. draugavo su lenkuojančiom šeimom ir lietuvino, 2. organizavo chorus, 3. jo visi, visi, visi klausè. Tačiau mokyklų inspektorius donžuanas Kazys Olšauskas (vèliau jis buvo Širvintuos) mok. Kavecką ištremè iš Kaišiadorių - kodèl jis per daug rimtas."

Kaip gerą pavyzdị paminèjo ir Kernavès mokytoją Juozą Šiaučiūną. Be visų gerų savybių, jis net ịkūrẻ Kernavès pradinejje mokykloje lietuvišką muziejų. O muziejų neturèjo net vidurinės mokyklos Jonavoje, Aukštadvaryje, Širvintose ir kitur.

„Tokị mokytoją - Juozą Šiaučiūną - reikia pagerbti, apdovanoti, ypatingai globoti... Tokių reikia visoj Vilniaus pafrontèj. Bet tokių maža yra."

Kunigas atsakymuose $\mathfrak{i}$ anketos klausimus skiria daug vietos Bažnyčios vaidmeniui, nes joje palankios sąlygos dirbti lietuvybès naudai. „Pamaldos pusiau lietuviškai, pusiau lenkiškai vyksta Aukštadvaryje, Vievyje, Kazokiškèse, Kernaveje, Širvintuose, Dubingiuose, bet tendencija yra [linkti] lietuvių pusèn. Daugelyje šių bažnyčių kunigai - Lietuvos patriotai, iniciatyvūs."

Tačiau svarbiausiu dalyku kun. N. Švogžlys laiko vyriausybès ir vyskupų susitaikymą, kad leistų „kunigams grižti prie skautų“. Pabrěžia, kad kol kas nereikètų ịvesti civilinès metrikacijos - „kol Vilnių atgausim ir kol Lietuvos Respublika nusistovès". Nes vyriausybės bandymai ịvesti civilinę metrikaciją ir žmonès papiktins, ir kunigai tam pasipriešins.

Kunigas reziumuoja, kad „Vilniaus sulenkintoj pafrontèj: 1. reikia daugiau skautiškų stovyklų, 2. reikia daugiau rimtų ekskursijų, 3. reikia nuolatinio turizmo, 4. reikia iškilmių: jas turi surengti kauniečiai (pav., Vilniaus Kalvarijų minėjimas Vievy 1933. VI. 29); 5. reikia daugiau lietuviško judejimo, 6. reikia daugiau lietuviško parado, 7. reikia daugiau lietuviškos galybès, 8. reikia Vilniaus pafrontej vasaroti, 9. reikia knygų apie Vilniaus pafrontę, 10. reikia Vilniaus pafrontę mylèti..." Jis siūlo Kaune atsižvelgti, kad „reikia lietuviškos vienybès - ne partinès, reikia lietuviško broliškumo ir meilès, tada ir Visagalis padès Vilnių laimèti ${ }^{“ 59}$.

59 Kun. N. Švogžlio atsakymai ị anketą 193312 12. LCVA, f. 500, ap. 1, b. 406, 1. 440-454. 
Kazokiškių bažnyčios klebonas kun. Juozas Čaplikas ${ }^{60} 1933$ m. gruodžio 12 d. siųstuose atsakymuose teigia, kad net Trakų (Kaišiadorių) apskrities II mokyklų rajono inspektorius Staugaitis yra „netikęs“, „liaudininkas, dèl išskaičiavimo prie tautininkų prisišliejęs, mokykloms kenksmingas: blogus mokytojus palaiko, gerus spaudžia“. Anot jo, Kazokiškių mokyklos II rajono Zabarijos kaimo mokytojas Elijas Aliukas - becenzis, girtuoklis, menkas pedagogas, palaikomas inspektoriaus. O geras mokytojas šioje vietoveje svarbu, nes Zabarija - „lenkų lizdas“. Apskrities I rajono Kaugonių mokytojas Steponas Vasiliauskas - vyras be idejos, tiktai apgraibomis atliekantis savo pareigas. O lietuvinimas vyksta per mokyklas, jei jų mokytojai idealistai.

Kaip gerą pavyzdị mini Aleksandriškių mokytoją Andrių Čiurinską, Kazokiškių mokyklos vedèją Oną Smolskaitę. Anot kun. J. Čapliko, „kadangi vyrų idealistų maža, o moterų daugiau yra atsidavusių savo pašaukimui, aš esu linkęs manyti: pr. mokyklų mokytojos tinkamesnè yra moterys-mergaitès, vyresnio amžiaus, bet nelabai senos“.

Kunigo manymu, „sulenkejjusiais lietuviais-lenkais“ pasitiketi negalima, todèl jų nereikètų priimti į Šaulių organizaciją, nes jie "ginklą atstatys prieš Lietuvą“. Pafrontę lietuvinant daug gali nuveikti geri valdininkai. Nes „blogi valdininkai žmones erzina savo girtavimu ir blogu elgesiu piktina. Sulenkejusieji visa tai priskaito lietuvių „pagoniškumui“.

Vievio ir Kazokiškių bažnyčiose pamaldos vyksta lietuviškai kas antrą savaitę. Vievio bažnyčios chore gieda „Lietuvos veikèjai“, t. y. atvykusieji čia gyventi iš kitų Lietuvos vietų. Kaip bendrą blogybę kunigas nurodo „tautiškumą“: „Tautininkai proteguojami, favorizuojami, tvirkinami, to-

60 Čaplikas Juozapas (1876 m. Samūniškių k., Merkinès valsč., 1961 m. Paakmenès k., Varénos r., palaidotas Akmens bažnyčios šventoriuje) - kanauninkas, tautosakos rinkejjas ir skelbejjas. Mokèsi Merkinèje, 1893 m. - Suvalkų gimnazijoje, 1895-1899 m. Vilniaus dvasineje seminarijoje. Per atostogas rinko tautosaką, ją J. Šimtakojo slapyvardžiu išleido Amerikoje 1899 m. („Trakiečių dzūkų dainos“). Kunigu ǐšventintas 1899 m. 1899-1900 m. Žiežmarių vikaras (šešis mėnesius). Žiežmariuose žadino lietuvybę. 1900$1901 \mathrm{~m}$. Valkininkų vikaras (tuo pat metu buvo ir Onuškio bažnyčios administratorius). 1901-1905 m. klebonavo Baltarusijoje, 1905-1910 m. Perlojos klebonas. 1910-1915 m. Darsūniškio ir Videniškių klebonas. 1915-1920 m. praleido pasitraukęs ị Rusiją. 19201929 m. Dusmenų, 1929-1948 m. Kazokiškių klebonas. Išdekoravo bažnyčios vidų, pastatė varpinę. 1948-1955 m. kalintas Sibiro lageriuose. 1955-1956 m. Bobriškio klebonas, 1956-1959 m. Vievio altarista. 1956 m. vyskupas Teofilius Matulionis suteike jam garbès kanauninko titulą. 1959-1961 m. Akmens klebonas. 
dèl visi rašosi tautininkais, net Lietuvos aiškūs priešai. Pasekmès žinomos: ramiu laiku turim daug vogimų valstybės ižde, karo metu turẻsim daug Lietuvos išdavikų. Žmonès Lietuvai naudingi, nemokantieji savo ištikimumu prekiaut yra ujami, nustumti, todèl ūpo prislegto, nusiminę. Toji tvarka visuomet blogai veiks pafrontės atlietuvinimą. Tas nenormalumas turès būt prašalintas: blogas valdininkas, mokytojas, kad ir tautininkas, turi būti skaitomas blogu, geras valdininkas, kad ir ne tautininkas, turi būti skaitomas geru. "“61

Atsakymas iš Beižonių, nepasirašytas ir be datos, tikriausiai rašytas Beižonių bažnyčios klebono kun. S. Rudžionio ${ }^{62}$ : iš 2000 parapijiečių 282 lenkai (1923 m. duomenimis). Mokykla buvo lenkiškame Eitulioniu kaime ir ten veike, bet viršaičio pastangomis buvo perkelta ị lietuvišką Vaitkūnų kaimą. Tačiau jis dèl potvynių buvo nepasiekiamas, todèl mokyklą teko kelti atgal.

Kontrabandininkai ị Lietuvą neša manufaktūrą. Kontrabandines prekes perka ir seniūnas. Valsčius ịrengè policijos būstinę. Susidariusias išlaidas dengia iš specialaus mokesčio. Gyventojai šiuo mokesčiu ir netaisomu vieškeliu per valdišką mišką Semeliškių apylinkèse nepatenkinti.

I savivaldybę pakliūva kalbantys ir lenkiškai, ir gudiškai, savininkai, kurių pasuose ịrašyta „lietuvis“, bet jie to nepripažįsta. Tèvai, nors ir leidžia vaikus ị pradžios mokyklas, bet ịkalbinẻja juos nesimokyti lietuviškai tikybos, lietuviškų pasakojimų (Ostruvkoje ir Naujalaukyje). 1926 m.

${ }^{61}$ Kun. J. Čapliko atsakymai ị anketą 193312 12. LCVA, f. 500, ap. 1, b. 406, 1. 455.

${ }^{62}$ Steponas Rudžiónis (slap. Vëjas) (1890 m. Jakuboniai (Gelvonų vlsč.), 1949 m. Vorkuta) Pirmojo pasaulinio karo metais buvo pasitraukęs ị Rusiją, $1915 \mathrm{~m}$. baigè Petrogrado kunigų seminariją. Nuo $1922 \mathrm{~m}$. klebonavo Beižionyse, pastatė ten medinę bažnyčią, vikaravo Gegužinès ir Kaišiadorių bažnyčiose 1927 ar 1928 m., buvo Tautininkų sąjungos narys. Nuo 1925 m. iki sovietinès okupacijos buvo Šaulių sąjungos narys, Semeliškių šaulių būrio vadas. 1936 m. apdovanotas Nepriklausomos Lietuvos medaliu ir Šaulio žvaigžde. Nuo 194404 - Gegužinès klebonas. Lietuvos pasipriešinimo sovietiniam okupaciniam režimui dalyvis. $1944 \mathrm{~m}$. gruodžio mèn. įstojo ị Lietuvos laisvės armiją, buvo paskirtas šios armijos 5-osios apygardos 2-ojo bataliono Organizacinio skyriaus viršininku, faktiškai vadovavo batalionui, pats sudare 2 kuopas. Nuo $1945 \mathrm{~m}$. rugpjūčio mèn. buvo Lietuvos laisvès armijos 5-osios apygardos štabo Karinio administracinio skyriaus viršininkas, palaikè ryšį tarp Didžiosios Kovos apygardos ir Lietuvos laisvès armijos 5-osios apygardos 2-ojo bataliono grupių. $1946 \mathrm{~m}$. vasario mèn. sovietinio saugumo suimtas, kalintas Vilniuje. $1946 \mathrm{~m}$. liepos mèn. NKVD Vilniaus igulos karinio tribunolo nuteistas $10 \mathrm{~m}$. lagerio ir $5 \mathrm{~m}$. tremties. 
jie norejo ịsteigti lenkišką mokyklą. „Mokytojai irgi mažai prisideda, lyg išponiškèję." Pasak kunigo, mokytojai su klebonu turètų veikti išvien, o „Semeliškių mokytojas Banionis su klebonu stačiai kovoja“. Moterys mokytojos veiklesnès, geriau prie žmonių prieina, rengia pramogas, eglutes (Kaluževičienè Vaitkūnų k.). Mokytojos Rajeckaitès (Žikaronių komplektas) inspektorius nevertina, nes bažnyčion per daug vaikšto. Mokytojai turètų mokèti vietos kalbas.

Toliau kunigas pateikia skaičius, kaip keitèsi vaikų mokejjimo kalbèti lietuviškai lygis. Pavyzdžiui, Aukštadvaryje 1930 m. iš 168 vaikų lietuviškai mokejjo poterius 28, 1931-1932 m. - jau apie 50 proc., o $1933 \mathrm{~m}$. iš 120 - net 100 proc. ( ,kas nemoka, tiems išpažintis atidedama kitiems metams, kol išmoks“). Vyskupo vizitacija Aukštadvaryje vyko lietuviškai, čia vaikų išpažinčių klausyta ir lietuviškai, ir lenkiškai. Jei jaunas kunigas nepriima (reikalauja tik lietuviškai), motinos siunčia "pas senị “63. Anksčiau pamokslai buvo sakomi lietuviškai ir lenkiškai. Nuo 1929 m. klebonas, kaip Šaulių valdybos pirmininkas, šaulių vardu pakeitè tvarką. Pasienio policijos žemesnieji tarnautojai elgiasi gerai, žmonès jais patenkinti.

Ypač išsamiai ị anketos klausimus atsakẻ Kaišiadorių vyskupijos kancleris dr. kun. prelatas Juozas Labukas ${ }^{64}$ (pasirašęs tik inicialais ir su grifu „Visai slaptai“). $1934 \mathrm{~m}$. balandžio $2 \mathrm{~d}$. jis pateikè savo mintis „del tikros padèties“, tačiau atsakydamas turejjo omenyje visą Kaišiadorių vyskupiją:

\footnotetext{
63 LCVA, f. 500, ap. 1, b. 406, 1. 462.

64 Juozapas Matulaitis-Labukas (1894 m. Greikonys, Stakliškių vls., 1979 m. Kaunas, palaidotas Šiluvos bazilikos šventoriuje) - Lietuvos vyskupas, socialinių mokslų daktaras. 1913-1918 m. mokèsi Vilniaus kunigų seminarijoje. 1918 m. ịšventintas kunigu. Vikaras Žasliuose, Kalesninkuose ir Švenčionyse. 1922-1926 m. studijavo socialinius ir ekonomikos mokslus Vokietijoje ir Šveicarijoje. 1926 m. socialinių mokslų daktaras. Nuo 1926 m. Kaišiadorių vyskupijos kurijos kancleris, nuo 1928 m. Kaišiadorių vyskupo J. Kuktos, vèliau vyskupo T. Matulionio generalinis vikaras. 1928 m. Kaišiadorių kapitulos prelatas, 1934 m. popiežius Pijus XI suteikè popiežiaus prelato titulą. $1942 \mathrm{~m}$. kaip kapitulinis vikaras valdė Kaišiadorių vyskupiją. Kartu su vyskupu T. Matulioniu 1946 m. SSRS saugumo suimtas ir nuteistas $10 \mathrm{~m}$. kalèti lageryje, ištremtas ị Sibirą. I Lietuvą sugrịžo 1955 m., paskirtas Raseinių altarista. 1957-1965 m. dėstė Kauno tarpdiecezinèje kunigu seminarijoje. 1965 m. gegužès 6 d. išrinktas Kauno arkivyskupijos ir Vilkaviškio vyskupijos valdytoju. 1965 m. gruodžio 5 d. Romoje konsekruotas vyskupu, paskirtas Kauno arkivyskupijos ir Vilkaviškio vyskupijos apaštališkuoju administratoriumi, šias pareigas ejo iki mirties. 1965 m. dalyvavo Vatikano II susirinkimo paskutinejje sesijoje. 1966-1979 m. Lietuvos vyskupų ordinarų kolegijos pirmininkas.
} 
„Svarbiausị lenkišką elementą Kaišiadoryse seniau prieš karą sudarydavo gelžkeliečiai, dažniausia vietos kilimo. Jie čia nuo senovès turèjo pasistatę namų, todèl po karo jie bemaž visi šičia ir grị̌zo. Be to, nemažas skaičius visokių kumpelninkų ir šiaip bėdnuomenès, persisunkusios lenkiška dvasia. Dabar daug pasikeitè lietuvybès naudai, visas jaunimas moka lietuviškai kalbèti ir gatvèse kalba; senesni žmonès irgi nelabai afišuojasi su lenkų kalba viešumoje. Bet namuose yra likę daug lenkiškos dvasios. Pirmiausia - daugelis šeimynų dar kalba lenkiškai.“

J. Labukas pateikè pavyzdį: $1932 \mathrm{~m}$. vasarą prie vieno darbo dirbo apie 30 miestelio darbininkų: 6 vyrai ir 24 merginos, bemaž visi 17-25 metų, daugelis jų jau buvo lankę lietuviškas mokyklas ir gerai išmokę lietuviškai, tačiau tarp savęs kalbejosi lenkiškai. Tarp jų keletas darbininkų buvo iš lietuviškų šeimų. Miestelis, nors išoriškai atrodè lietuviškas, „bet dvasioje ir kalboje yra lenkiškas, ne tik jis šeimynoje-namie ir dažnai viešumoje lenkiškai kalba, bet ir lenkiškoj dvasioj galvoja. Ir tai, kas svarbiausia, kad tuo pasižymi jaunimas, kuris yra užaugęs lietuviškose apystovose. Tepasikeičia aplinkybès lenkiškon pusèn arba tesusidaro palankios sąlygos kaip buvo 1926 metais ${ }^{65}$ - lenkiškai propagandai, visas toks elementas virs lenkišku. Šiais 1934 metais esu girdèjęs, kad Kaišiadoryse viename išoriniai lietuviškame name kaledojančiam kunigui, kuris pasveikino lietuviškai, demonstratyviai atsako lenkiškai: „Na wieki wiekow. “66 Kaišiadoryse lietuvybès plètimasis turejo geresnes sąlygas: stovejo ilgai kariuomenè (lietuvių), yra daugiau valdininkijos, yra daugiau mokyklų ir kultūrinio judejimo, ko nèra kituose provincijos miesteliuose, nekalbant apie sulenkejjusius kaimus. Todèl kiti šiame krašte miesteliai lietuvybès žvilgsniu yra liūdnesnèje padèty.“

Prelatas J. Labukas pažymėjo (beje, jis pats Vakarų Europoje buvo studijavęs ir ekonomiką), jog ekonominė krizė Lietuvoje pasireiškè ne taip stipriai, kaip Lenkijoje, o tai gerai žino Lenkijos puseje gyvenantieji žmonès, „pas kuriuos šis ekonominis motyvas sugriauna ne vieną priekaištą prieš Lietuvą“. Tarp abiejose sienos pusèse gyvenančių žmonių buvo gana glaudūs ryšiai, mat ūkininkai turèjo geresnes sąlygas ją pereiti, ypač lauko darbų metu (dalis gyventojų dirbamų laukų buvo ir vienoje, ir kitoje sienos puseje). Kitapus administracinės linijos su Lenkija,

65 Turimas galvoje kairiųjų valdymas $1926 \mathrm{~m}$. antroje pusẻje iki perversmo (aut. past.).

${ }^{66}$ Per amžių amžius. 
pasienyje, gyvenantys „yra bemaž visi sulenkejję" ir dèl dažnų kontaktų „lenkiškai dvasiai sustiprinimą gauna iš anos pusès. Ypač tas jaučiama Vilniuj ar pafrontèj ruošiamų lenkiškų bažnytinių bei tautinių švenčių metu“. Geresnè ekonominè Lietuvos padètis suteikè abiejose pasienio pusèse gyvenantiems žmonèms „didelį motyvą nusistatyti už Lietuvą“. Kita vertus, $\mathfrak{x}$ ekonominès padèties gerinimą iš Lietuvos pusès per mažai kreipta dèmesio. Kaip pavyzdi jis pateikia bekonų prièmimo punktus, mat visoje Trakų apskrityje buvo tik vienas toks punktas (Kaišiadoryse), ir tai atidarytas gana vèlai. „Argi Kaišiadorių punktas gali aptarnauti visą apskritị? Dėl ko neatidaryti bekonų priemimo punktų tokiame Vievy - netoli pasienio, tokiose Semeliškèse, Aukštadvary, Onušky? Tas ne tik prisidès prie ekonominio pakilimo krašto, kur, kaip žinoma, yra labai smulkus ūkis, blogos žemès, bet taip pat prie didelès propagandos - šioje ir anoje pusèje - mūsų naudai. Panašiai reikia pasakyti ir apie pienines, kurių, tiesa, yra daugiau negu bekonų priemimo punktų. Tenka skaityti spaudoje ir girdèti kalbant, kad Traku apskrity pieninès duoda nuostolius, reiškia: neapsimoka jas remti. Man atrodo, kad turint omeny gyventojų tamsumą, vargingumą, ūkių žemą kultūringumą, negalima taikyti jiems bendras mastas. Čia reikia sudaryti ypatingas sąlygas, kuriose galima būtų šitas kraštas pakelti.“

Prelatas J. Labukas, kalbėdamas apie valdžios ịstaigų vaidmenị, teigia, kad „administracijos organai galètų irgi žymiai prisidèti prie atlietuvinimo akcijos“. Jis primena atvejus, kai Širvintų valsčiuje pasitelkus seniūnus gyventojams buvo dalijama literatūra, nukreipta prieš vyskupus ir dvasininkiją.

J. Labuko nuomone, didelị vaidmenị galètų vaidinti Šaulių organizacija, tačiau „ị šaulius ne visada rašosi pats taurusis elementas. Dažnai i juos patenka čia pasieny padaužų - elementų, kurie kaimo visuomenèje neturèdavo gero vardo ir kurie tik ginklo sumetimais stoja sąjungon, kad paskiau galètų suvesdinèti su kaimynais sąskaitas. Šis priekaištas apie šaulius dažniausia tenka girdèti iš sulenkejusių pusès“. Taip pat šauliams prikiša ir netaktišką elgesị („užgauliojantis atsinešimas prie sulenkèjusių, pravardžiavimas“) bei tikybos reikalus, tokius kaip „šokių ir vakaruškų ruošimas bažnyčios draudžiamomis dienomis bei pamaldų metu, manevrai pamaldų metu; netaktingas ir neleistinomis priemonemis kišimasis ị pamaldų tvarką, propaganda prieš Bažnyčią bei dvasiškiją ir t. p." 
Prelatas ragina lietuvinimo darbą susieti su organizacijų veikla: „Prie tokių organizacijų aš priskaitau lietuviškas bažnytines bei lietuviškas tikybinio pobūdžio kultūrines organizacijas. Minètos organizacijos paruošia sulenkèjusius bažnytinei įtakai lietuvių dvasioje, gi bažnytinės apystovos ir lietuviška įtaka bažnyčioje ji patraukia i tokio pat pobūdžio organizacijas už bažnyčios sienų, kur toks asmuo tautinèj atmosferoj globojamas. Tokio darbo ir veiksnių kombinacija atlietuvinimui yra condicio sine qua non. Tokiomis priemonėmis lenkai naudojasi Vilnijoj, jomis - t. y. darbu bažnyčioje, sujungtu su darbu už bažnyčios sienų, lenkai naudojosi senovejje mūsų liaudies sulenkinimui. Tik tokiomis priemonèmis galima pasiekti pačią sulenkèjusią liaudi..“

Prie tokių bažnytinių organizacijų J. Labukas priskiria bažnytines brolijas (tretininkų, Gyvojo rožančiaus, Maldos apaštalavimo), tikybos ir kultūros (katalikių moterų, katalikiškojo jaunimo „Pavasario“, vaikų „Angelo Sargo“) draugijas. Tinkamiausia lietuvinimo darbui esanti „angelaičių“ organizacija, nes „senių mes neatlietuvinsim, jiems reikia statyti kryželį; daugiausia, ką galima su jais padaryti, tai kad jie nebūtų lietuviško judejjimo priešininkais“. Tačiau „vaiko išmokinimas lietuviškai kalbèti dar neišsprendžia jo lietuvybès klausimo. Šeimynos ịtaka, ypač jo tikybinis gyvenimas, lenkiškoje kalboje ir dvasioje paralyžiuoja tokiame vaike lietuvybès pradus."

Toliau J. Labukas atkreipia dèmesị ị nepakankamą inteligentijos vaidmenị: „Bendras ligšiolinio tokio veikimo bruožas yra tai, kad vietos inteligentija, ypač daugelis veikejjų, neturi bemaž jokio kontakto su sulenkinta liaudimi, nepažissta josios gyvenimo ir reikalų, netgi dažnai neturi pasitikejjimo liaudyje. Nepasitikejjimo jais priežastys - indiferentiškas arba priešiškas nusistatymas tikybos atžvilgiu (bažnyčios nelankymas ar net propaganda prieš bažnyčią), dorovinis pakrikimas $<\ldots$. . Girtuokliavimas bei baliavojimas šiuo krizio metu sukelia liaudyje murmèjimo ir priekaištų, kad, būk, valdininkams mažai nukarpyta algos.“

Kaip kenksmingą lietuviškumui reiškinị J. Labukas ịvardijo ir lietuvių vyrų vedybas su lenkaitėmis, nes „lietuvis nèra labai atsparus ištautejjimui“. Toks lietuvis pasiduoda žmonos ịtakai, namuose su ja ir vaikais kalba lenkiškai ir pats pradeda vengti „lietuviško veikimo“. Taip esą ir mišriose rusiškose šeimose, nes „rusiškas elementas mažiau rodo tendencijos silpnèti negu lenkiškas“. Todèl J. Labukas palaiko kai kurių virši- 
ninkų nuostatą vedusius lenkaites iškelti i „ "grynai lietuvišką vietą“.

Lenkiškų „Pochodnios“ mokyklų 1934 m. visoje Kaišiadorių vyskupijoje tebuvo dvi (po vieną Ukmergès ir Alytaus apskrityse). Taigi, $1926 \mathrm{~m}$. kilusio bumo kurti lenkiškas mokyklas Trakų apskrityje neliko. „Sulenkejusi liaudis labai remia lenkiškas mokyklas bei slaptą mokinimą. I tokias mokyklas suveža vaikų net iš tolimesnių apylinkių. Dažnai tenka nugirsti iš lenkuojančių nusiskundimų, kad jiems neleidžiama turèti savo lenkiškų mokyklų."

Lenkiškumui palaikyti pasienyje anksčiau buvo nemokamai platinamas lenkiškas laikraštis „Chata Rodzinna“, „bet dabar jau susiranda to laikraščio ir prenumeratorių“. O viena naujausių lenkiškos propagandos priemonių, anot J. Labuko, yra „keliaujantieji knygynèliai“. Jų daugiau Ukmergès apskrityje, bet pasitaiko ir Trakų apskrityje. „Daugely vietu gyventojai gauna pasiskaityti lenkiškų knygų iš vietos dvarų, ypač kumečiai tuo aprūpinami.“

Lenkiškumą propaguoja ir „lenkų bankeliai“, kurie suteikia paskolas lengvesnèmis sąlygomis, negu Žemès ūkio bankas. Tokị kaimo klientą „bankelis“ paima ì savo rankas ir nebeleidžia jokiam lietuviškumui pasireikšti: „Atrodo, kad lenkai ị bankelius kreipia daug demesio ir net stengiasi kai kuriose vietose esamus lietuvių smulkaus kredito bankelius paimti $\mathfrak{i}$ savo rankas. Taip buvo mėginta Aukštadvary su smulkaus kredito bankeliu, kuriam lenkų banko būk tai buvo pasiūlyta lengvomis sąlygomis didelis kreditas, jei bankelis grąžins Lietuvos bankui iš jo gautas paskolas.“

Anot J. Labuko, „beveik visose didesnèse vietose, kur vyrauja lenkiškas elementas, jaučiama tyli, slapta lenkų akcija, matyt, gerai organizuota. Svarbiausi tos akcijos motyvai - tai tikybinių ir tautinių teisių gynimas“. Kaip pavyzdị jis pateikia faktą, kad Semeliškių valsčiuje vieno kaimo (tiksliau - „akalicos“) vaikai atsisake lietuviškai mokytis tikybos ir šių pamokų visada vengdavo.

J. Labuko nuomone, jeigu mokytojams per tuos keliolika nepriklausomybès metų būtų buvę duoti nurodymai, jie būtų galèję „žymiai atlietuvinti visą šią pasienio zoną“. Tačiau padaryta labai nedaug, ir jei taip bus toliau - sunku tikètis greitai ją „atlietuvinti“. Mokytojai neturi kontakto su liaudimi, jaunimu ar netgi jos vengia. Be to, mokytojams suartèti su žmonèmis trukdo ir nuolatinis jų kilnojimas iš vienos vietos ị kitą. Kodèl mokytojai stengiasi atsiriboti nuo šios veiklos? J. Labukas įžvelgia kelias 
priežastis. Anksčiau mokytojai buvo verčiami stoti $\mathfrak{i} \dot{\mathfrak{i}}$, ,vilkus ${ }^{\text {“67 }}$ ir „nemaža veiklesnių mokytojų dèlei savo veiklumo šičia pasieny nukentèjo<...>. Iš kitos pusès - jei mokytojas ir supranta savo pareigą dirbti atlietuvinimo darbą, tačiau veiks aplenkdamas bažnyčią ar netgi "betikybine“ kryptimi - tuomet kils konfliktas su vietos dvasininku, kurio pareiga bus parapijiečius apsaugoti nuo pragaištingos ịtakos“.

J. Labukas vienareikšmiškai nepareiškia, kuris mokytojas - vyras ar moteris - labiau tinka dirbti šiame krašte. Jo nuomone, moteris, kaip lipšnesnè, labiau patrauks vaikus ir motinas, jai lengviau vaikus bus mokyti poterių, dainų, žaidimų. O vyrai labiau imponuos vyrams ir jaunimui. Jis siūlè steigti mokyklas ne lietuviškuose, o lenkiškuose kaimuose (tada jie greičiau sulietuvès, bus užkirstas kelias privačiam lenkiškam mokymui).

Taip pat, J. Labuko nuomone, reikia vargingesnius vaikus aprūpinti drabužiais ir apavu, vadovèliais ir rašymo priemonèmis. Jie būtų patenkinti, pavyzdžiui, baigę pradžios mokyklą ar kita proga apdovanoti lietuviškomis gyvenime praversiančiomis knygomis - maldaknyge, „Lietuvos istorija“ ar kokiu dainų rinkiniu. Tačiau tai reikètų daryti taktiškai, o ne taip, kaip buvo kartą Aukštadvario valsčiuje. Ten vaikus apdovanojo maldaknygèmis, tačiau mokytojai patys išdalijo knygas, nę̨traukdami kunigo: „Vaikai gavę dovanų pasigyrè tèvams, kurie tuojaus liepè mesti pečiun maldaknyges arba nunešti parodyti klebonui, ar nebus tos maldaknygès eretiškos."

J. Labukas siūlo mokyklose įvesti giedojimo pamokas (kad vaikai iprastų lietuviškai giedoti, tai pakeistų giedojimą lenkų klaba „pakasynose, gegužinèse pamaldose“). Primena, kad prieš porą metų vieno apskrities mokyklų inspektoriaus išleistame aplinkraštyje buvęs nurodymas vaikus mokyti bažnytinio giedojimo, tačiau kai kuriems karštiems patriotams jis nepatiko kaip atsiduodantis klerikalizmu. Pageidautina, kad vaikai mokytųsi skaityti iš maldaknygių, nes „jei kaimas kad ir mokès

67 Turima galvoje radikali organizacija, atsiradusi $1927 \mathrm{~m}$. pabaigoje, - Lietuvos tautinè apsauga „Geležinis Vilkas“, kurios vyriausiuoju vadu tapo A. Voldemaras. Ji pašalinus iš valdžios, nemažai „vilkų“ tam pasipriešino, todèl organizacija buvo paleista. Kuriant šią organizaciją, buvo numatyta, kad savarankiškos politinès programos ji neturès. Tai užfiksuota ir jos statute: „Geležinis Vilkas“ nèra partija ar sąjunga su tam tikra išdirbta ir vykdoma programa, bet yra aktyvi sargyba, kurios tikejimas ir idejja jungia visus atgimusius dorus lietuvius, naujos santvarkos kovotojus ị kuopas kovai su antitautiškumu ir svetimu, priešvalstybiniu gaivalu.“ 
lietuviškai kalbèti, gi melsis ir giedos lenkiškai, tai jis dar lengvai gali būti šiandien lietuviškas, gi ryt - lenkiškas“.

J. Labuko manymu, „ligšiol, kaip aukščiau minèta, tikra prasme nebuvo ir nèra planingo, iš anksto apgalvoto, visas vietoje esančias jègas jungiančio bendro darbo masių atlietuvinimui. Jeigu buvo kas, tai buvo tik atskirų organizacijų bei atskirų asmenų pripuolamieji darbai“. Planingam darbui trukdo Bažnyčios ir valstybès konfliktas. Dèl to „daugelis asmenų, ypač valdininkai ir mokytojai, kuo mažiausiai dedasi ị kokị nors veikimą, kad nebūti užangažuotiems“.

J. Labukas prisiminė ir istorinị vietinių kunigų vaidmeni - jie esą „seni kovotojai už lietuvybę Vilnijos krašte; ne vienas iš jų yra nukentèjęs už tai. Jųjų pastangomis ir darbu pasiekta tai, kad daugelis šio krašto parapijų yra jau lietuviškos“. Bažnyčia turètų pamaldas lenkų kalba įvesti palaipsniui, kad nesuerzintų žmonių. Parapijų, kuriose prieš 10 metų visos pamaldos buvo lenkiškos, ,jau nebeliko bažnyčioje nieko lenkiška“.

Iš pradžių lietuviškos pamaldos buvo rengiamos kas ketvirtą sekmadienį, kai apsiprasta - kas antrą ir t. t. Kartais lenkiškos pamaldos vykdavo 2-3 kartus per metus. Tai reikèjo daryti kuo taktiškiau, kad būtu mažiau triukšmo. O patriotams norisi labai greito efekto. Apie tai reikia mažiau rašyti spaudoje, nes pasigyrus, kad ši vieta jau sulietuvinta, lenkai apie tai ištrimituos savo laikraščiuose, o tai atsilieps ir Vilnijos krašte.

Apibendrindamas J. Labukas pažymi, kad per keliolika metų praleista proga organizuotai ir planingai vykdyti lietuvinimą, kad šis procesas buvo daugiau negatyvus (neleidžiant reikštis lenkiškumui, bet kartu per mažai rūpinantis pozityviu darbu), kad dabar lietuvinimas vyksta sunkiau, nes lenkai tapo geriau organizuoti, gausiau šelpiami, atsirado atsparumas, be to, už sienos Vilnijoje ị vienos lenkiškos mokyklos uždarymą atsakoma kelių lietuviškų mokyklų uždarymu ir lietuvių veikèjų sodinimu i kalejjimus. Daroma prielaida - jeigu Lenkijos ir Lietuvos santykiai gerès, bus dar sunkiau, nes suaktyvès legalūs lenkų veiksmai, daug pabègusių agitatorių grị̌s ị Lietuvą ir t. t. ${ }^{68}$

${ }^{68}$ Dr. J. Labuko 1934 m. balandžio 2 d. atsakymai ị anketos klausimus. LCVA, f. 500, ap. 1, b. 406, 1. 287-298. 


\section{AGRONOMŲ ATSAKYMAI I I ANKETOS KLAUSIMUS}

1933 m. gruodžio 19 d. Trakų apskrities agronomas (nepasirašęs pavardès, tačiau iš parašo galima spręsti, kad Valatka) siūlo, „kad Trakų apskrities gyventojai greičiau grị̌tų prie savo sentèvių kalbos ir pakiltų bendra kultūra, reikètų imtis štai tokių priemonių:

1) valdžios ir savivaldybès ịstaigose vartoti tik lietuvių kalbą; 2) kad sumažinus analfabetų skaičių, daugiau steigti vakarinių kursų suaugusiems; 3) daugiau Trakų apskr. naujokų (ūkininkaičių) imti ị kariuomenę ir skirti juos $\mathfrak{i}$ tas dalis, kurios yra labiau kultūringuose rajonuose; 4) Trakų apskr. laikyti kariuomenę; 4) pavyzdingai sutvarkyti kelius; 5) pravesti plentą, kuriam yra labai daug medžiagos (akmenų) vietoje. " ${ }^{69}$

Kitas agronomas - iš Aukštadvario - V. Rimkus 1933 m. gruodžio 19 d. atsaké, kiek gyventojų kalba lenkiškai: Onuškio valsčiuje - apie 40 proc., Aukštadvario valsčiuje - apie 60 proc., Semeliškių - 45 proc. Jie galètų kalbèti ir lietuviškai, nes mokančiųjų dauguma, tačiau, kadangi yra ịpratę, kalba lenkiškai.

Reikètų atkreipti dèmesị ì suaugusiųjų švietimą, jo organizavimą, platinti spaudą (pigiau arba nemokamai). Ūkininkams teikti ịvairias pašalpas (kaip anksčiau buvo daroma) „veislinei medžiagai“, žemès dirbimo ịrankiams, geresnei sėklai ịsigyti, trobesių statybai ir kt. „Jei stiprès ekonomiškai, stiprès ir tautiškai." Nors yra daug organizacijų, bet jose dalyvauja tik lietuvių šviesuomené - inteligentai, o vietos gyventojai ị organizacijas beveik „nesideda“. Išimtis - jaunųjų ūkininkų rateliai.

Jei „lenkuojantys“ užsirašo ị šaulius - tai tik turẻdami tam tikrų tikslų.

Mokytojai visi tautiškai susipratę ir per mokyklas daug padaro. Tuo tarpu kunigai per bažnyčias galètų daug padaryti lietuvindami žmones, jei norètų, „bet jie taikosi prie gyventojų, daugiau demagogiški. Nors atrodo, kad jie varo atlietuvinimo darbą"70.

Anonimiškame pranešime (greičiausiai rašytame Lietuvos banko Trakų skyriaus vedèjo Juliaus Jakulio) teigiama, kad lenkai mėgina sutvirtinti savo pozicijas pasienio rajonuose, siekdami paimti savo globon smul-

69 Trakų apskrities agronomo 19331219 raštas Trakų apskrities komendantui. Ten pat, 1. 459 .

70 Ten pat, 1. 460 . 
kaus kredito draugijas. 1933 m. pradžioje Kauno lenkų smulkaus kredito draugija siūlè Aukštadvario ūkininkų smulkaus kredito bankui 7 proc. paskolą su sąlyga, kad jis grąžins visus kreditus Lietuvos ir Žemès bankams, o naudosis tik jų kreditais, nors pati Kaune skolino už 10-12 proc.

Pavyzdžiui, Žiežmarių draugijos vedejjas „gaudyte gaudè paskolas ir išdavè savo nariams gana stambias sumas“, o dabar jų būklè sunki, skolininkai neišgali net procentų sumokèti. Reikia kredito draugijoms apdairumo, kad dirbtų patikimi asmenys, „pastatyti sumanius, sąžiningus veikejjus, tikrus lietuvius, gerus visuomenininkus. Panašių asmenų Trakų rajono kooperatyvai neturi" ${ }^{\prime 71}$.

\section{MOKYTOJŲ ATSAKYMAI}

1933 m. gruodžio 16 d. mokytojas iš Daugirdiškių S. Dulke $\dot{e}^{72}$ daug rašè apie Semeliškių valsčių, kad jo valdybos knygose, kur pateikti gyventojų pasų duomenys, nenurodyta tautybè, „o klausinèti tiesiog piliečių yra nepatogu“. Be to, to valsčiaus valdyboje teiravosi ir mokytojai.

Nemoka lietuviškai vaikai nuo 8 metų: Daugirdiškių kaime - 106 (moka 80), Užkryžių kaime - 39 (moka 18), Prudžionių kaime - 58 (moka 39), Lelivos kaime - 20 (moka 38).

Kiek žinoma, administracinẻ linija dažniausiai pereinama kontrabandos gabenimo, giminių lankymo ir šnipinejjimo tikslais. Anot mokytojo, geriausi motyvai ịtikinti, kad Lietuvoje geriau, yra šie: lenkai giriasi, kad turi savo druskos - tačiau ji neịperkama ir gyventojai ją neša iš Lietuvos kaip kontrabandą, nes druska - kasdieninè prekè ir turtuoliui, ir vargšui. Okupuotoje Lietuvoje (t. y. Lenkijos pusejje) dar brangesnis yra cukrus, sacharinas, tabakas, pipirai... Blogai, kai Lietuvoje valstybès iždo eikvo-

\footnotetext{
71 Ten pat, 1. 461.

72 Daugirdiškių mokyklos mokytojas S. Dulkè buvo aktyvus Semeliškių valsčiaus veikèjas, vienas aktyviausių savo apylinkès Tautininkų organizacijos lyderių.
} 
jimas (pašto ženklų $\mathfrak{l}^{73}$ afera ir pan.) sudaro palankias sąlygas lenkų agitacijai.

Mokytojas S. Dulkè puikiai ir plačiai aiškino kalbos, istorijos žinių reikšmę. Mokejo paaiškinti, kad kalbantys ta pačia kalba ir tos pačios tikybos gali būti skirtingų tautų. Nes „lenkininkų“ pagrindiniai argumentai buvo gana primityvūs: kas kalba lenkiškai - tas lenkas, jog Vilniaus krašte gyvena lenkai, kad čia pigesni drabužiai, todèl geriau gyventi...

Semeliškių valsčiaus savivaldybėje „(pulk. p. Matulionio ir kitų rūpesčiu) pavyko pravesti visus lietuvius. Jei kyla nesusipratimų, tai ne iš tautybès srities“. „Iki šiol (o ypač seniau) tautybès klausimas buvo sprendžiamas tik iš gyventojų pareiškimų. Dažniausiai ị minètą klausimą gyventojai atsako (turiu galvoje Semeliškių valsčių): „Nežinau... Namie kalbame gudiškai (lenk.). Tiesa, žmona gudiškai (lenk.) dar sunkiai kalba, o vaikai supranta ir lietuviškai... Kaip norit, taip rašykit."

Mokytojas pageidauja, kad pasienio policijos viršininkai neleistų policininkams „lenkuojančiu gyventojų kolioti“, vadinti išgamomis, lenkais, gudais ir pan., kas dažnai pasitaiko. Iš Daugirdiškių kaime gyvenančiu 7 policininkų tik 2 netinkamai elgiasi. Pažangesni vietos gyventojai tuo piktinasi. „Juk lietuvi pravardžiuoti lenku - berods didžiausias užgavimas!“ <...> Reikia tik mokèti juos patraukti, kad nežiūrint jų kalbos („kuri toli gražu ne lenkiška!"), jie yra lietuviai. Reikia mokèti išnaudot vietinius vietovardžius, pavardes (Daugirdiškèse yra 39 gyventojai, turintys pavardę Dulkè, Gaidukas (35 gyventojai) ir t. t.) <...> Pademarklinijos gyventojų kalba - gudiškas lenkiškas kratinys. Tos kalbos griaučiai (galūnès, kirčiai, išsireiškimo būdas) yra lietuviški. ${ }^{\text {"74 }}$

Šaulių sajungos Semeliškių būrys savo tikslo nepasiekia, nes blogai kontroliuojamas. Gerai sekasi šiuo požiūriu Tautininkų sąjungai, kuri geriau tvarkoma iš centro ir apskrities. Semeliškių Tautininkų skyrius sie-

73 Tikriausiai turima galvoje garsaus poeto brolio, tuometinio Lietuvos pašto ir telegrafo valdybos direktoriaus Adolfo Sruogos sumanyta afera, kai buvo tyčia leidžiami netikri, turintys defektų Lietuvos pašto ženklai, daugelio filatelistų perkami didelèmis kainomis. Spauda 1933 m. plačiai rašè apie šią aferą. 1935 m. A. Sruoga buvo nuteistas 15 metų kalejjimo, mažesnes bausmes gavo jo talkininkai. Pašto ženklų afera - dažniausiai minimas ir bene vienintelis pavyzdys, kompromituojantis Lietuvos valstybės institucijų veiklą.

${ }^{74}$ Kaip pavyzdị pateikia vietinių vartojamas lenkiškas frazes: „prywioz wozik žagarou“ („atvežiau vežimaiti žagarų"), „pošoru pšinios“ („atnešiau pašaro“), „pšinios rezginy siana“ („atnešiau rezginę šieno") ir t. t. 
kia kiekviename kaime turèti bent po vieną tautininką, „per kuri galima varyti liet. akciją ir gauti iš jo reikalingų žinių tai akcijai racionalizuoti“.

Platesniu mastu lietuvinimo darbą dirba mokyklų inspektorius V. Staugaitis ir Semeliškių mokyklos vedejjas A. Palionis. „Savivaldybès organai išduodami pasus nutautusiems gyventojams turi sugebėti be spaudimo išgauti prisipažinimą, kad interesantas yra lietuvių tautybès.“

Tautininkų sajungai Semeliškių valsčiuje reikia rūpintis, kaip kuo greičiau sustabdyti laikraščio „Chata Rodzinna“ siuntimą, ir siekti, kad bažnyčioje lenkų pamokslai ir evangelijos būtų panaikintos. Semeliškių valsčius gauna 32 egz. "Chatos Rodzinnos“, didesnę pusę nemokamai, Daugirdiškès jos neužsisako.

Lenkiškų mokyklų Semeliškių valsčiuje jau nebėra, tačiau, kaip teigia mokytojas S. Dulkè, valstiečių liaudininkų ir socialdemokratų viešpatavimo metu jų buvo net trys, ịkurtos vien dèl praktinių motyvų. Tuo metu Trakų apskrityje privalomas mokslas nebuvo įvestas, todèl valdžia neduodavo daug pašalpų (pvz., drabužiams). O lenkų „Pochodnios“ agitatoriai žadejo duoti veltui ne tik knygų, bet ir „rašomosios medžiagos“, drabužių ir net maisto. Be to, kai kur buvo aiškinama, kad ir lietuvių valdžia, supratusi lenkų kalbos naudingumą, toms mokykloms pritaria ir su laiku jų ịsteigs visoje Lietuvoje. Visi Semeliškių valsčiaus mokytojai tautiškai susipratę ir aktyviai prisideda prie krašto atlietuvinimo. Būtų geriau, kad mokytojais čia būtų skiriami vyrai. Pagyvenę tinka labiau, nes tarp jų mažiau „karštuolių ir išsišokèlių“, ir apskritai per mokyklas lietuvinimo akcija „varoma geriausia“.

Ne visi dvasininkai vienodai veikia, nors dvasininkams, anot mokytojo, sąlygos veikti palankios. Pavyzdžiui, Beižonių parapijoje jokių lenkiškų pamaldų nèra (rodos, ir Aukštadvario?), o Semeliškių bažnyčioje kiekvieną sekmadieni skaitoma lenkiška evangelija ir sakomas pamokslas. Tautinių švenčių proga Semeliškių klebonas bando stiprinti gyventojų tautinị sąmoningumą. Ypač šiame darbe aktyvus ir už bažnyčios ribų naujai atvykęs vikaras Baužys. Siūlo Semeliškių bažnyčioje lenkiškas pamaldas panaikinti, o kur tai būtina - pamokslus tyčia sakyti „lenkiškai lietuvišku kalbos kratiniu“ (pvz., „Moja mieli parapijonys!“)”7.

75 S. Dulkès 19331216 atsakymai ị anketos klausimus. LCVA, f. 500, ap. 1, b. 406, 1. 464470. 
Vievio mokytojas Vytautas Buinevičius 1933 m. gruodžio 12 d. parašè emocijų persmelktą laišką, nes matyti, kad tarp jo ir komendanto buvo kilusi ịtampa dèl anketos „išlaikymo paslaptyje“, tačiau mokytojas, nors ir „be ūpo“, trumpai atsake i jos klausimus. Lietuviškesni kaimai Vievio valsčiuje - Pakalniškių ir Abromiškių. Kituose kaimuose gyvena beveik vien „lenkuojantieji“. Santykiai su už sienos gyvenančiaisiais arba ūkiniai, arba šeiminiai. Kontrabanda vyksta, nes už sienos pigesnė „manufaktūra“, tačiau „,neteko girdèti, kad kas išsitartų apie anos pusés geresnị gyvenimą bent kuriuo atžvilgiu“.

Saikingus mokytojo atsakymus iliustruoja trumpi teiginiai, kaip „taip“ (atsakant, ar iš kariuomenès „lenkuojantieji“ grižzta sulietuvinti), arba „sunku pasakyti“, „negaliu nurodyti“ ir t. t. Anot mokytojo, visi Vievio valsčiaus savivaldybės tarnautojai (viršaitis, sekretorius, taryba ir seniūnai) - lietuviško nusistatymo. Tuo metu nepasitaikè (bent mokytojui neteko girdèti) norinčiụjų užsirašyti lenkais. Bet seniau, valsčiaus vadovybę sudarant kitiems asmenims, buvo visko: „Kas dèl priemonių vartojimo, reikia pasakyti, kad lenkuojantis elementas, ar jis šiaip, ar taip galvotų, vis tik bijo lenko vardu vadintis. Ta aplinkybe reikia naudotis. Pasisekimas priklausys nuo pasą išduodančio asmens taktikos ir gabumų."

I klausimą, ar administracijos organai ippareigoti lietuvinimo darbą dirbti, jam „sunku atsakyti“, nes per organizacijas veikti sąlygos neblogos, bet šauliai turètų turèti „ypatingų parèdymų“ nutautintose apylinkèse. Vievio valsčiuje yra 3 būriai, kurie „veikia, rodos, normaliai. Tik Kazokiškių būrys, kiek teko girdèti, pasižymi ypatingu nesusitvarkymu. Jokių ypatingų priemonių kraštui atlietuvinti šauliai, rodos, nesiima“. Lietuvinimui tinkamos visos organizacijos. Vievyje yra Tautininkų, jaunalietuvių, VVS, Skautų ir Jaunųjų ūkininkų organizacijų skyriai.

V. Buinevičius mano, kad ịstaigoms ir asmenims reikètų dirbti „bendrai susitarus“. Tačiau, jo manymu, „šiandien dažnai pasitaiko, kad, ką vienas padirba, tą kitas suardo“. Plačiai skaitoma "Chata Rodzinna“, kuri „rodos, siunčiama senai antrašais, nemokamai“. Lenkiškų organizaciju negirdèti, tačiau, „kaip teko patirti, Kauno lenkai nori issiskverbti $\mathfrak{i}$ čia įsteigtą gudų švietimo d-ją ir per ją veikti“.

Lenkiškų mokyklų nèra. Organizuotos propagandos irgi. „Mokytojai visi tautiškai susipratę; prie liet. darbo ne tik prisideda, bet dažniausiai jam ir vadovauja. Visų autoritetas, rodos, stovi tinkamoj aukštumoj.“ 
Mokytojai skiriami ị tą kraštą bendra tvarka. Mokytojais dirba 6 vyrai ir 11 moterų (greičiausiai turi omenyje Vievio valsčių). „Lyties skirtumai neturi reikšmès. Turint galvoj jaunimo organizavimą ir sporto propagandą, mano nuomone, moterų darbas čia labai svarbus. Vis tik, mokyklų vedejjai ir atskirų komplektų mokytojai turètų būti vyrai. Moteris galima skirti tik ten, kur dirba keli mokytojai. Amžiaus skirtumas neparodo žmogaus privalumų.“

Bažnyčios veikimo sąlygos nèra labai blogos. Vievio valsčiuje, Vievio ir Kazokiškių parapijose, pamaldos laikomos pakaitomis lietuviškai ir lenkiškai (kas antrą šventadienị). „Lietuviškų pamaldų ịvedimas buvo padarytas su Vievio klebono žinia ir, rodos, iniciatyva (mat, to įvedimo dalyviai-piliečiai visus nuopelnus priskiria sau). ${ }^{\text {" } 76}$

Anoniminiame atsakyme ị anketos „Per mokyklas“ klausimus (rašè tikriausiai mokytojas, iš rašto, biografinių faktų ir polèkio galima spręsti, kad tai buvo Kaišiadorių amatų mokyklos direktorius Antanas Škèma, nes kamputyje mažomis raidėmis Žutauto parašyta „A. Škėma“). Rašto autorius siūlo mokytojais ,ị sulenkèjusị kraštą“ skirti tikrus lietuvius, kurie visai nemoka lenkų kalbos ir, pirmiausia, yra tikri patriotai. Mokytojai gali ir suprasti lenkų kalbą, bet patys jokiu būdu neturi jos vartoti, kad visur susirinkimuose būtų kalbama lietuviškai. „Lenkai moka nuduoti ir dažnai pradeda kalbą lietuviškai, bet tuoj toliaus traukia lenkiškai ir dažnas lètas ir nuolaidus lietuvis pasiduoda."

Mokytojas, anot A. Škėmos, jokių būdu neturètų vesti lenkès. Visų jų draugų ir pažistamų, kurie vedè lenkes, šeimos tapo lenkiškos. Rusų laikais tarnaudamas Lenkijoje matè, kaip lenkų motinos „prieš kryžių su ašaromis pasižadėdavo mylèti ir vartoti tik savo lenkišką kalbą, nors kuri ištekès už kitataučio“. Taigi, jam atrodo, kad „norèdami užmigdyti savo sąžinę drịsta kalbėti, kad gryna lenkè gali būti ir lietuvè. Tas yra absurdas - lenkè patriotè ir liks lenkë“.

Lavinant vaikus reikia supažindinti juos su Lietuvos gamta, geografija, poezija, dainomis. Nes kas buvo tolimuose kraštuose, visada ilgèjosi Lietuvos gamtos, lietuviškų dainų. „Mano nuomone, dar ir šiandien svetimtaučiai - ypatingai lenkai ir vokiečiai, daug žalos daro Tẻvynei Lietuvai, nuduodami ir skaitydami save lietuviais, pjudo ir šmeižia jiems žalingus

76 V. Buinevičiaus 19331212 laiškas ir atsakymai i anketos klausimus. Ten pat, 1. $474-475$. 
lietuvius patriotus. Iš tokių patriotų lietuvių ne vienas bijodamas intrigụ pasyviai žiūri ị lietuvinimo darbą."

A. Škèmos nuomone, „norint sustiprinti lietuvinimo akciją pafrontejj, reikalinga praplèsti lietuviškų mokyklų tinklą. Mokytojais skirti tik rinktinius žmones: tikrus lietuvius, gabius, taktingus ir iškalbingus. Svetimtaučiai ir svetimšaliai čia jokiu būdu netinka. Be to, mokyklose turi būti ypatingai išplèsti ir gerai pastatyti lituanistikos dalykai: Lietuvos istorija, Lietuvos geografija ir Valstybès mokslas, ir kiti dėstomieji dalykai, kiek yra galima, turi būti persunkti lietuviškumo dvasia." Lietuvinimas turi vykti ne tik per šventes, o „planingai ir nuolatinai ${ }^{\mathrm{c} 77}$.

Dar vienas anoniminis atsakymas su trumpais komentarais, tačiau nuosekliai neatsakant $\mathfrak{i}$ klausimyną greičiausiai priklauso Trakų (Kaišiadorių) apskrities II mokyklų rajono inspektoriui Staugaičiui. Anot jo, nutautėję pasienio valsčiai - Vievio, Semeliškių, Aukštadvario, Onuškio, ypač pirmi trys. „Nutautimas įleidęs šaknis jau ị šeimą, tad ir lietuvinimas turi būti pradètas nuo šeimos. Papročiai, kalba, giesmès, šermenys, laidojimai lenkiški, bažnyčios apeigos dar žymia dalia lenkiškos. Nesimato bažnyčios akcijoje aktingos lietuviškos linijos, yra kas tai, ką galima būtų pavadinti tūpčiojimu prieš lenkus dvarininkus. Tas pat pastebèta kai kuriose savivaldybèse ir kitose ịstaigose."

Nutautėjimą išlaiko šeimos papročiai, lenkų dvarininkų atkaklumas laikantis lenkiškumo, kai kurių dvarų duodamos lenkiškos knygos, veltui siunčiamas laikraštis "Chata Rodzinna“, dovanojamos maldaknygès ir panašiai. „Lenkuojančių“ šeimų vaikai mokyklose išmoksta lietuviškai žodžiu ir raštu, gauna dovanų lietuviškų maldaknygiu ir neturi progos mokytis lenkiškai.

Vienas svarbiausių veiksnių būtų Aukštadvario vidurinès mokyklos išplètimas, kad „iš jos išeitų stipresnis vietos inteligentijos luomas“. Savivaldybès ir kitos ịstaigos turètų tik lietuviškai kalbèti, „čia yra pagrindinis dèsnis išmokinti jau suaugusius lietuviškai“. Pasus išduodant griežtai sekti, kad nebūtų užrašomi „gudais“, „lenkais“, nes tai „labai veikia nutautusius moraliai ir kartu duoda daug medžiagos statistikai“. Todèl valsčių viršaičiai ir sekretoriai šioje srityje neturi daryti klaidų.

I šaulius vietinius reikia priimti atsargiai, nes yra norinčių ìstoti ir buvusių peoviakų, ir panašių, turinčių savo tikslų. Daug padeda liaudies

77 Anoniminis raštas. Ten pat, 1. 476-477. 
universiteto paskaitos ir „taktiškas džentelmeniškas šio krašto šviesuolių apsiejjimas su vietos žmonèmis“. I šị kraštą skiriami valdininkai turi būti blaivūs, pavyzdingo elgesio, taktiški. Lenkybès lizdai - pas šlèktas, dvaruose. Aukštadvario kredito draugijoje buvo toks Homeneckas - „didis lenkas ir stiprus, tačiau susikompromitavo ir pabėgo Lenkijon. Dabar lenkų vadų akcija susilpnèjo. Išsprogdinimas Homenecko buvo rengtas planuotai. Taip reiktų daryti, pulti visus jų lizdus be pasigailejjimo. Jeigu lizdų nedraskysim, lenkų paukščiai ilgai čiulbès“.

Mokytojai dirba sèkmingai, tik reikia daugiau atsargos leitenantu („žinoma, rimtų“), daugiau vyrų, o ne moterų. Mokytojas turi vietoje gyventi ilgiau, kad susigyventų su vietiniais, tada taps įtakingesnis. Labai svarbu, kad mokytojai dirbtų bendraudami su kunigais, taip yra daugelyje nutautejjusių valsčių, „gi ypatingai tai ryšku Vievyje, Beižonyse, Aukštadvaryje ir Semeliškèse“. Labai padeda mokytojų vaikams dovanojamos maldaknygès ${ }^{78}$.

Trakų (Kaišiadorių) V šaulių rinktinès kapitonas Ciunis išvardijo sulenkejjusius kaimus: Žaslių valsčiuje - Surveliai, Šilonys ir kiti, iš viso 11 kaimų (pusiau lietuviški-lenkiški neįtraukti), Kaišiadorių valsčiuje - Palomenè, Karlauka, Penki valakai. Vievio valsčiuje tokių kaimų 27, Aukštadvario - net 31, o Onuškio - 19. Mažiausiai „lenkuojančių“ kaimų - Kietaviškių valsčiuje, tik 3 - Perkūnkiemis, Ašakieniai, Taduliškis neprenumeruoja laikraščių dèl tamsumo ir neturto ${ }^{79}$.

Iš Trakų apskrities komendanto susirašinèjimo matyti, kad apskrityje jau anksčiau vyko tiek organizuotas, tiek stichiškas nemokamų lietuviškų maldaknygių platinimas vaikams. 1934 m. pradžioje ịvairių mokyklų vedèjai teikè ataskaitas mokyklų inspektoriams, kaip jiems sekasi platinti lietuviškas knygas. Pavyzdžiui, 1934 m. vasario 27 d. Karapolio mokyklos vedejjas pranešè, kad sausio 16 d., dalyvaujant tèvų komiteto nariui A. Kubekui, kun. A. Žilinskui, vaikams, kurie tais metais buvo darbštesni, dalijamos maldaknygès, ir žadejo vèl apdovanoti tuos, kurie „mokysis gerai lietuviškai skaityti ir kurie pasižada iš jų visuomet melstis tiek namie, tiek bažnyčioje $\mathrm{e}^{\text {80 }}$.

78 Ten pat, 1. 478.

79 Kap. Ciunio sudaryta apskrityje skaitomų laikraščių suvestinè. Ten pat, 1. 369-370.

${ }^{80}$ Karapolio mokyklos vedejo raštas Trakų apskrities II rajono mokyklų inspektoriui. Ten pat, 1. 316 . 
Aleksandriškių pradžios mokyklos mokytojas (greičiausiai A. Čiurinskas) rašè Trakų apskrities II mokyklų rajono inspektoriui apie knygelių dalijimą, kad tai svarbu ${ }^{81}$.

Kazokiškių mokyklos mokytoja $1934 \mathrm{~m}$. vasario 21 d. pranešè inspektoriui, kad mokiniams maldaknyges dovanoja jau antrą kartą. Visi, kurie gavo tokią dovaną, džiaugèsi, tačiau nebuvo įmanoma visų norų patenkinti, nes maldaknygių trūko. Tokios dovanos buvo teikiamos per Kalèdų šventes prie vaikams papuoštos eglutès ${ }^{82} .1934 \mathrm{~m}$. kovo $20 \mathrm{~d}$. II mokyklu rajono inspektoriui Kazokiškių mokyklos vedèja O. Smolskaitẻ padèkojo už gautas lietuviškas maldaknyges, kurias dalija vaikams. „Yra vaikų, kurie turi ir lietuvišką, ir lenkišką maldaknygę, tačiau ị bažnyčią nešasi lietuvišką, o tèvams pasiteisina, kad jiems sunku lenkiškai skaityti." Mokytoja išdalijo vaikams maldaknyges, kiekvienoje įrašiusi vaiko vardą ir pavardę. Tą pačią dieną pas ją atbègo 16 metų mergaitė „balsiai raudodama“, kuri susijaudinusi kartojo žodị „knyga“. Pasirodo, ji pametė gautą maldaknygę, tad jai nuraminti beliko padovanoti kitą - „mergaitè staiga nurimo, èmé juoktis ir linksma nubègo namo“. Mokytoja galvojo, kaip pasielgs suradę pamestą knygą. Ji nustebo, kad lietuvišką knygą radęs žmogus jos nesudraskè, o grąžino mergaitei. Išmokę skaityti iš lietuviškų maldaknygių žmonės skaito ir kitas knygas, nes anksčiau tik paveiksliukus išsikarpydavo ${ }^{83}$.

Aleksandriškių mokyklos vedèjas (be pavardès, be datos, greičiausiai A. Čiurinskas) maldaknyges dalijo kasmet per Vasario 16-osios šventę. Pavyzdžiui, tais metais buvo pranešta - kas geriau mokysis, gaus dovanų po maldaknygę. Net jaunesni mokiniai èmè itikinèti, kad jau gerai skaito. I šventę pakvietė Kernavès kleboną kun. N. Švogžli-Milžiną, tèvų komitetą, tèvus, jaunimą. Susirinko apie 200 žmonių. Apie Vasario 16-osios reikšmę kalbėjo mokytojas A. Čiurinskas, apie tautos atgimimą kun. N. Švogžlys. Po kalbų sušukta „valio" tautos vadui, savanoriams, ministrams, inspektoriams, mokytojams, tèvams ir jaunimui. Paskui

${ }^{81}$ Aleksandriškių mokyklos mokytojo raštas Trakų apskrities II rajono mokyklų inspektoriui. Ten pat, l. 318.

${ }^{82}$ Kazokiškių pradžios mokyklos mokytojos 1934 m. vasario 21 d. raštas Trakų apskrities II rajono mokyklų inspektoriui. Ten pat, 1. 345.

${ }^{83}$ Kazokiškių pradžios mokyklos vedejos raštas Trakų apskrities II rajono mokyklų inspektoriui. Ten pat, 1. 321. 
mokyklos choras padainavo kelias dainas. Tada „mokytojų radio įnešta $\mathfrak{i}$ klasę, kur perduota buvo ir muzika iš Kauno“. Anot A. Čiurinsko, baigęs mokyklą vaikas rašo ir skaito, susirašinèja su giminėmis lietuviškai, nors namie kalba, kaip ịpratęs. Mokytojo manymu, lietuviška maldaknyge išstumia lenkišką ${ }^{84}$.

Drabužnykų mokyklos vedèjas $1934 \mathrm{~m}$. vasario 24 d. rašo, kad dalijo maldaknyges priejjusiems išpažinties. Jomis naudojasi ne tik vaikai, bet ir šeima. Būna, kad anksčiau naudojo lenkiškas, bet joms susinešiojus, turẻdami lietuviškas, lenkiškų nebeperka, naudojasi lietuviškomis ${ }^{85}$.

Nikronių mokyklos vedèjas 1934 m. vasario 24 d. rašė inspektoriui, kad vaikams irgi dovanoja maldaknyges, iš kurių jie noriai meldžiasi. „Tẻvai, nors ir nutautę, tam nesipriešina, jie tame numato tik religinio jausmo stiprinimą vaikuose ir, žinoma, džiaugiasi tuo. " ${ }^{86}$

Miciūnų mokykloje maldaknygès vaikams dalintos 1933 m. gruodžio 21 d. dalyvaujant Aukštadvario parapijos klebonui ir mokyklų kapelionui kun. Albinui Žilinskui bei Miciūnų mokytojui Jonui Kvikliui ${ }^{87}$.

Semeliškių valsčiaus Neciūnų mokyklos mokytojas 1934 m. vasario 17 d. rašo, kad pasaulietinio turinio knygelių prieš kelerius metus duodavo ir Švietimo ministerija. Jos - dar geriau, nes maldaknyges skaito tik jos savininkas per šventes, o pasaulietines knygas - visi ir visada ${ }^{88}$.

Trakų apskrities II mokyklų rajono inspektorius $1934 \mathrm{~m}$. kovo $22 \mathrm{~d}$. perduoda šias iš mokytojų gautas žinias ir jų pasiūlymus Trakų apskrities komendantui, iškeldamas sumanymą dovanoti jaunimui lietuviškus giesmynèlius, kad galima būtų išnaikinti „ı̧sisenejjusị paprotị giedoti lenkiškai per pakasynas, šermenis, budynes" ${ }^{\text {"89, }}$, kad per pirmus tris 1933 m. mène-

${ }^{84}$ Aleksandriškių mokyklos vedèjo raštas Trakų apskrities II rajono mokyklų inspektoriui. Ten pat, 1. 323.

${ }^{85}$ Drabužnykų mokyklos vedèjo 19340224 raštas Trakų apskrities II rajono mokyklų inspektoriui. Ten pat, 1. 325 .

${ }^{86}$ Nikronių mokyklos vedejo 19340224 raštas Trakų apskrities II rajono mokyklų inspektoriui. Ten pat, 1. 327.

${ }^{87}$ Miciūnų mokyklos vedejjo 19340209 raštas Trakų apskrities II rajono mokyklų inspektoriui. Ten pat, 1. 333.

${ }^{88}$ Neciūnų mokyklos vedejjo 19340217 raštas Trakų apskrities II rajono mokyklų inspektoriui. Ten pat, 1. 337.

89 Trakų apskrities II mokyklų rajono inspektoriaus 19340322 raštas Trakų apskrities komendantui. Ten pat, 1. 350 . 
sius 44 mokyklos surengė 533 susirinkimus ir daug kitų renginių (paskaitų, vakarų, eglučių, dainų, ekskursijų ir t. t.), juose dalyvavo 37000 gyventojų. Pateikta lentelé, kurią sudarè pradinių mokyklų inspektorius ${ }^{90}$.

II Trakų apskrities mokyklų rajonas apėmė Vievio, Aukštadvario, Semeliškių ir Onuškio valsčius, t. y. toliausiai nuo apskrities centro Kaišiadorių ir arčiausiai pasienio, kur labiau paplitusi ir lenkų kalba. Kiek kitoks vaizdas susidare iš pranešimų, kuriuos atsiuntė Trakų apskrities I mokyklų rajono mokytojai. Pavyzdžiui, Žaslių pradžios mokyklos Nr. 1 vedejas Adolfas Baumilas (kartu jis buvo ir Žaslių šaulių būrio valdybos pirmininkas) $1934 \mathrm{~m}$. kovo 2 d. rašè komendantui, kad valsčiuje „lenkuojančio elemento“ yra, tik žymiai mažiau negu palei administracinę liniją.

Žaslių valsčiuje dirba 24 mokytojai, dauguma jų priklauso tautinėms organizacijoms, visi 25-40 m. Kelios vyresnio amžiaus mokytojos yra krikdemiško nusistatymo. Apie mokytojų, gyvenančių kaimuose, kultūrinị darbą A. Baumilas nieko konkretaus pasakyti negalejo, jo nuomone, dvasininkams prie lietuviškumo platinimo prisidèti sąlygos palankios, miestelėnus, kurių dauguma „lenkuojantys“, reikètų ịtraukti ị bažnytinius chorus. Kunigams pamokslus vertètų sakyti ne tik apie Dievą, Bažnyčią, bet ir apie meilę tèvynei ${ }^{91}$.

Trakų apskrities I mokyklų rajono inspektorius Rapolas Butkus apskrities komendantui apibūdino visos Trakų (Kaišiadorių) apskrities padètị, tačiau remdamasis patirtimi, igyta prieš ketvertą metų, kai gyveno Kaišiadoryse:

„Trakų apskrity labiausiai lenkuoja Vievio, Semeliškių, Aukštadvario ir Onuškio valsčiai. Galima sakyti, kad 75 \% Vievio vals. gyventojų namie kalba lenkiškai gudišku žargonu, tačiau apie pusè gyventojų moka valstybinès kalbos. Semeliškių vals. lenkuoja kokia penkta dalis, Aukštadvario vals. apie $40 \%$, Onuškio vals. apie $15 \%$. Steigiant lenkiškas mokyklas 1926 m. pasižymėjo aktingumu Vievio vals. Zabožès kaimas, Panerių dvaro apylinkė, Samiliškių vals. Bagdonių km., Zailgų kaimas ir Daugirdiškių kaimas, Aukštadvario vals. Karapolio rajonas ir Onuškio vals. Nikronių ir Vieštartonių kaimai.

90 Trakų apskrities II mokyklų rajono inspektoriaus 19340322 raštas Trakų apskrities komendantui. Ten pat, 1. 371-372.

91 Žaslių mokyklos vedejo A. Baumilo 19340301 raštas komendantui. Ten pat, 1. 383. 
Pasuose lenkais užsirašiusių labai maža, turbūt valsčių savivaldybių tarnautojai šia kryptimi yra reiškę iniciatyvos. Iš kitos pusės, tatai parodo, kad lenkuojantieji nebūtinai laiko save oficialiai lenkais.

Rinkimai ị buvusius seimus parodydavo, kad lenkuojančių yra keleriopai daugiau. Daviniai apie balsavusių skaičių yra valsčių savivaldybių raštinèse, iš kurių galima pastebèti jų dislokaciją.

Sulenkejjusių tarpe yra ịvairaus aktyvumo žmonių. Tuo žvilgsniu stipriausias elementas yra miesteliuose (Žasliai, Vievis, Aukštadvaris, Onuškis), kaimuose sulenkejjimas nèra tiek sąmoningas. Yra apylinkių, kur lenkejjimas buvo prasidèjęs visai neseniai. Ten sulenkejjimas greit nyksta. Aukštadvario apylinkejje Gedanonių, Tolkuškių rajonai. Pafrontès sulenkejjimą ir bendrai atsilikimą palaikè didelis tamsumas (yra kaimų, kur senesni žmonès nè vienas nemoka rašyti). Žemės nederlingumas ir ūkininkavimo primityvumas taip pat palaiko lenkybę. Šitos aplinkybès labai sunkina artintis prie aukštesnès kultūros.

Lietuvinimas pafrontès buvo pradètas per bažnyčias ir per slaptas mokyklas, gyvavusias jau prieš karą. Kur anksčiau ịvestos pamaldos lietuviškai ị bažnyčią, ten žmonès greičiau palinko ị mūsų pusę (Semeliškès, Užuguostis). Kazokiškio ir Vievio bažnyčios vèliau susilaukè pamaldu lietuvių kalba, todèl ten stipriau laikosi lenkybè. Prie kiekvienos bažnyčios sulenkèjusioje apylinkejje turètų būti geras bendras choras, kuris mokètų giedoti lietuviškai ir lenkuojančius.

Nesant privalomo mokymo, mūsų pradžios mokyklos pafrontèje turèjo nedaug mokinių ir lietuvinimas nèjo pakankamai greitu tempu. Itvedus privalomą mokymą visi mokyklinio amžiaus vaikai turi išmokti mokyklose lietuviškai ir tatai pavyksta, nors ne galutinai. Kad vaikai neužmirštų lietuviškai, pafrontejje reikalinga kai kurių naujų priemonių, kurių nèra grynai lietuviškose apylinkèse.

Vaikai turi išmokti pafrontès mokyklose bažnytines giesmes lietuviškai, gauti maldaknygių ir kitų knygų. Mokiniai turi palaikyti ryšius ir toliau su mokykla. Jie turi gauti iš mokyklos skaityti lietuviškų laikraščių ir knygų, jau išèję iš mokyklos. Tuo tikslu pradžios mokyklų knygynai turi būti labai žymiai padidinti. Žinoma, tai liečia pafrontès rajonus. Bendrai pafrontẻje mokykla turètų aprūpinti gyventojus knygomis, kuo dabar rūpinasi „Pochodnia“. Prie mokyklų turètų būti šioki toki suaugusių vaidintojų būreliai ir sporto mėgejų vienetai. Žiemos vakarais visi norintieji turètų rinktis $\mathfrak{i}$ 
mokyklą ir ten bendrai skaityti laikraščius. Miesteliuose (Žasliuose, Vievy, Aukštadvary, Onušky) turètų būti ịsteigti vaikų darželiai.

Aiškus dalykas, kad mūsų puseje ūkininkams gyvenimas lengvesnis: mažesni mokesčiai, valstybinè parama organizuojant pieno ūkị, auginant bekonus ir bendrai agronominè pagalba tvarkant ūkị. Nieko nèra panašu okupuotame Vilniaus krašte. Daug kenkia ta aplinkybė, kad pafrontès juosta yra toli nuo kelių ir didesnių centrų. Ši aplinkybé atpigina vietos produktus. Čia reikalinga valstybinè pagalba. Visi kaimai pafrontèje be jokios eilès turi išsiskirstyti vienkiemiais. Pienines turètų organizuoti Ūkio rūmai, nes vietos gyventojui, nesant inteligentų, tatai sunkiai pasiekiama.

Lenkuojantis elementas turètų būti atsargiai priimamas ị šaulių sąungą, nes pasitikejjimą gali išnaudoti blogam. Mokytojais pafrontèje tinka žmonès, pažistą ši kraštą ir moką gerai lenkiškai, aišku, patriotai, vyrai, sugebą dirbti organizacinį darbą. Labai reikia vengti mokytojų ir tarnautojų kitose ịstaigose, siunčiamų í pafrontę drausmès sumetimais. Nusikaltę čia jokiu atveju nepasitaisys, o pagadins labai daug.

Mokytojai neturètų pašiepti lenkuojančiu ir dèl niekų skųsti, kad tuo būdu galètų daugiau ịsigyti simpatijų ir laimètų tokiu būdu žmonių orientacijoje. Visi valstybès tarnautojai pafrontejje negali tyčiotis iš gyventojų“, - perspejjo mokyklų inspektorių R. Butkus ${ }^{92}$.

\section{SAUGUMAS IR POLICIJA}

Anoniminis (su komendanto prierašu, kad tai - saugumo rajono viršininkas) autorius atsako tik ị porą anketos klausimų. Pirmiausia jis pateikia statistinius duomenis, kad „gyvenančiu 25 kilometrai nuo sienos Trakų apskrityje viso yra 7026 žemès savininkai-ūkininkai. Iš jų oficialiai lenkais užsirašiusių tik 17 , baltgudžiu 600 , rusų 105 , žydų 26 , totorių 2 “. Pilietybès požiūriu iš jų kaip svetimšaliai užregistruoti tik du. Iš paminètųjų 18-20 proc. yra "griežtai lenkuojančių“ ir beveik nemokančiu lietuviškai. Pavyzdžiui, Žaslių valsčiaus Korsakų kaime yra 40, Benkūnų kaime - 19, Burbiškių - 20 ūkininkų, Dainavos - 36, Šešonių - 48, Maskoliškių - 7, Senkonių - 26 ūkininkai, Padvarių - 21 ūkininkas, ir jų

92 Inspektoriaus R. Butkaus raštas Trakų apskrities komendantui. Ten pat, 1. 384-386. 
šeimos yra „griežtai lenkuojančios“ ir lietuvių kalbą mažai vartojančios.

Santykiai su kita pasienio puse - daugiausia kontrabandiniai. Propaganda mažai turi įtakos (išskyrus fanatikams), nes anos pusès ūkininkai „daugiaus suspausti ir nusiskundžia“. Materialiné Lietuvos būklè geresnè, nes mažesni mokesčiai ir taip griežtai nevaržoma. Kai kurie pereina sieną ir šnipinėjimo tikslais, „,ǐ̌ ko taip pat uždarbiauja“93.

1933 m. gruodžio 20 d. karo komendantui i anketos klausimus atsakęs Trakų apskrities policijos vadas teigè: „Visame pasienyje sąlygos šaulių sąjungai veikti žymiai blogesnès, nei kitur. Lenkuojantieji šauliams nepritaria ir ị šaulių sąjungą nesirašo. Kurie ir užsirašo ị šaulių sąjungą, tai su tikslu, kad galètų laikyti ginklą, bet kaipo šauliai yra visai pasyvūs." Šauliai pasienyje lietuvindami gyventojus mažai deda pastangų.

Policijos vadas pateikia kai kurių arčiausiai pasienio esančių šaulių būrių statistinius duomenis. Onuškio valsčiuje - 7 būriai: Onuškio būrys - apie 60 narių (vadas - Juozas Kubilius), Dusmenų - 40 (vadas Bronius Katlauskas), Žilinų - apie 35 (vadas - mokytojas Martinkaitis), Kaniukų - apie 30 (vadas - pasienio policijos I rajono viršininkas), Gudakiemio - apie 30 (vadas - Petras Karūžas), Antokolio - apie 40 (vadas - Salvas Karpičius), Panošiškių - apie 60 (vadas - Pasienio policijos II rajono viršininkas).

Semeliškių valsčiuje - 3 būriai: Semeliškių 9-as būrys - apie 40 narių (vadas - mokytojas Staniūnas, būrio pirmininkas - mokytojas Palionis), Beižonių 12-as būrys - apie 30 narių (vadas - mokytojas Kazakevičius, pirmininkas - kun. S. Rudžionis), „šimtinė šaulių“ - apie 120 narių (vadas - atsargos vyr. ltn. Jurgelis). „Bendrai visi būriai pakrikę ir reikalingi nuodugnaus pertvarkymo, nes didesnè šaulių dalis yra neaiškūs ir ị sąjungą yra įstoję anksčiau ir su tikslu, kad gavus ginklą. "Vievio valsčiuje Vievio būrys (apie 25 narius) ir Pakalniškių būrys (apie 20 narių).

Anot policijos vado, ir kitos organizacijos (tautininkai, jaunalietuviai, Vilniaus vadavimo sąjunga ir pan.) „atlietuvinimo darbu“ ir veiklumu nepasižymi.

Pasienyje, „išskiriant vieną kitą mokytoją, iš privačių asmenų, gyvenančių vietoje, veikèjų atlietuvinimo darbe nèra“. Valstybès, savivaldybių ir kitų organizacijų tarnautojai daugiausia „žiūri vien tik savo asmeninių reikalų ir prie atlietuvinimo darbo labai mažai teprisideda“.

93 Anoniminis raštas Trakų apskrities komendantui. Ten pat, 1. 479. 
„Lenkiškas elementas“ beveik nesireiškia, nes nei valdišku, nei visuomenès lèšomis išlaikomų lenkiškų mokyklų nẻra, dẻl jų organizuotos agitacijos taip pat. Dažniausiai gaunami lenkiški laikraščiai - 38 (Onuškio valsčiuje „Chata Rodzinna“ - 36, „Dzien Kovenski“ - 2 egz.), Vievio valsčiuje - 55. Kitose vietose lenkiškų laikraščių gaunama labai nedaug. Pasienyje mažai skaitančių lenkiškai, nes daug gyventojų nemoka skaityti.

Mokytojai šiame krašte tautiškai susipratę (daugiau arba mažiau), tačiau lietuvinimo darbo mažai dirba, išskyrus vieną kitą. Mokytojus skiria švietimo ministerija, atsiklaususi vietinio mokyklų inspektoriaus. Onuškio, Vievio ir Semeliškių valsčiuose yra 36 mokytojai vyrai ir 26 moterys. Šiame krašte labiau tiktų vyrai nuo 25-35 metų, nes yra veiklesni, turi daugiau iniciatyvos „ir fiziniai ne taip greit nuvargsta“.

Dvasininkai šiame „lietuvinimo darbe“ pasyvūs, ypač Onuškio valsčiuje. Onuškio bažnyčioje pamokslai sakomi ir giedama lietuviškai. Semeliškių bažnyčioje šventadieniais sakomi du pamokslai - lietuviškai ir lenkiškai, „nors lenkiškai pamokslo sakyti nebūtų reikalo. Čia yra grynai vietos klebono užsispyrimas ir pamègimas lenkiškų papročių ir kalbos“. Vievio bažnyčioje vieną sekmadienį pamaldos laikomos lietuviškai, kitą - lenkiškai, nes „lenkuojančių" parapijoje yra daugiau. Kazokiškių taip pat. Lietuvinimo darbe pasižymèjo Beižionių klebonas kun. S. Rudžionis, „kuris bažnyčioje įvedè lietuviškas pamaldas. Be to, už bažnyčios ribų taip pat dirba atlietuvinimo darbą, dalyvaudamas ịvairiose organizacijose, kaip tai: šaulių, Tautininkų sąjungoje ir kitose“. Policijos vado nuomone, ši kraštą lietuvindami daug galètų padaryti kunigai, bet jie to nedaro, o reikètų, kad dvasininkai įtrauktų tikinčiuosius ị ịvairias organizacijas „atlietuvinimo darbui“, „bet ne akcijai vesti prieš Vyriausybę “94.

Trakų apskrities pasienio baro viršininkas A. Virbalis, atsakydamas i anketos klausimus, pabrèžè, kad gyventojai Vievio, Semeliškių, Aukštadvario ir iš dalies Onuškio valsčiuose „yra daugumoje sulenkeję ir vartoja lenkų kalbą“. Daugiausia nemokančių lietuviškai yra Vievio valsčiuje, iš dalies - Semeliškių valsčiuje. Semeliškių valsčiuje dar yra ir gudų. Kituose valsčiuose, nors namie ir kalba lenkiškai, bet moka ir lietuviškai.

„Visi su mažom išimtim pasienio gyventojai gyvena skurdžiai, kultūroje atsilikę ir, nors kalba lenkiškai, bet oficialiai save vadina lietuviais.

\footnotetext{
94 Trakų apskrities policijos vado 19331220 raštas apskrities komendantui. Ten pat, 1. $480-481$.
} 
Kiek yra oficialiai lenkais užsirašiusių tikrų žinių nėra, bet reikia pasakyti, kad susipratusių lenkų, t. y. kurie vadina save lenkais, yra mažai ir jie jokio aktyvumo neparodo.“

Daug gyvenančių pasienyje turi giminių kitoje pusẻje. Kas turi kitoje pusejje žemès - gauna leidimus lauko darbus dirbti, kiti pereina sieną nelegaliai. Iš sulaikomų „nelegalų“ pusè eina per sieną pasimatyti su giminėmis, 30 proc. - parsigabenti kontrabandos, 20 proc. - kitais tikslais.

„Lenkai pirmaisiais metais sulenkejjusius gyventojus stengèsi patraukti savo pusèn įvairiais viliojančiais pažadais ir grasinimais, kad lenkai užims Lietuvą ir visus vietos gyventojus už lietuviškumą smarkiai baus. Gana ilgą laiką sulenkèję vietos gyventojai laukẻ lenkų ir buvo priešingi lietuviškumo akcijai, bet laikui bėgant lenkų pažadai ir grasinimai nustojo savo reikšmès ir sulenkejję vietos gyventojai lietuviškumo akcijai lengviau pasiduoda. Dabartiniu krizès laiku Okupuotos Lietuvos gyventoju padètis yra sunkesnè ir jie kenčia didelị skurdą. Jie yra apkrauti didesniais valstybiniais ir savivaldybiniais mokesčiais. Tų mokesčių išieškojimas yra labai griežtas. Ūkio pagerinimo srity nieko nedaroma ir ūkininkais mažai rūpinamasi. Mūsų pasienio gyventojai tai visa matydami nenori ir bijosi lenkų ir noriai pildo mūsų valdžios reikalavimus."

Paskelbus mobilizaciją dalis buvusių karių i paskirtą vietą neatvyks. Nors ị Šaulių sąungą stoja dažnai dèl to, kad galètų turèti ginklą ir uniformą. Jaunimas mėgsta vakarones, pramogas, lietuviškas dainas ir žaidimus. Buvę kariai vietinius pamoko lietuviškų kariškų dainų. Kaimuose lenkiškų dainų negirdèti.

Ne visi mokytojai prisideda prie „lietuviškos akcijos“, „yra tokių mokytojų, kurie tik savo pamokas atlieka ir prie lietuviško darbo visai neprisideda“. Paminimi Vievio valsčiaus Malovolès mokyklos mokytojas Simonaitis („seno amžiaus“), Vilūniškių mokyklos mokytojas Bakšys (kairiųjų pažiūrų, socialdemokratas), Semeliškių valsčiaus Daugirdiškių mokyklos mokytojas Dulkè, „baltgudis“ ir „vietoje lietuviškos dvasios skiepija vietos gyventojams baltgudiškumą“. To paties valsčiaus Zailgu mokyklos mokytojas Severinas ir Granapolio mokytoja Paškevičiūtė „atlieka vien tik mokyklos darbą“, taip pat ir Onuškio valsčiaus Gervinių mokytoja Maziliauskaitè. Visi kiti dirba organizacijose (Šaulių, VVS [Vilniui vaduoti sąjungos], tautininkų), rengia vakarèlius, suaugusiųjų kursus. Geriausiai šiame krašte mokytojauti tinka jaunesni vyrai. „Tam tikras 
nuošimtis galima ir reikalinga būtų skirti moteris, nes ruošiant vakarèlius, ypač vaidinimus, reikalingi abiejų lyčių mokytojai.“

Lenkiškų mokyklų Trakų pasienio bare nèra. Vietos lenkai laikosi pasyviai, propagandos nevaro. Per Vievio paštą gauna 53 lenkiškus savaitraščius ir 2 dienraščius. Vievio valsčiaus Zabarijos kaime Vaicekauskas dažnai iš Kauno lenkų knygyno parsiveža seno leidimo lenkiškų patriotinių istorinių knygų ir duoda vietiniams skaityti ${ }^{95}$.

\section{POVEIKIS TARNAVUSIEMS KARIUOMENE்JE}

Dabar galima būtų trumpai apibendrinti pastabas dèl lietuvybès poveikio tarnavusiems kariuomeneje. Trakų pasienio policijos baro viršininkas A. Virbalis pabrěžè, kad buvę kariai vietinius pamoko kariškų lietuviškų dainų ${ }^{96}$.

1933 m. gruodžio 20 d. Trakų apskrities viršininko vardu apskrities policijos vadas taip atsakè dèl kariuomenès „lietuviškos akcijos ịvertinimo“:

„a) lenkuojantis elementas grị̌ta iš kariuomenès nežymiai sulietuvintas, kai kurie betarnaudami kariuomenejje pramoksta pakankamai lietuviškai kalbèti ir grižę iš kariuomenès išoriai laiko save lietuviais, bet viduje - lenkais, išskiriant vieną kitą paskirą individą;

b) laikui bėgant, buvę tokie kariai namuose susiduria su lenkuojančiu elementu, vèl pasiduoda senai namų dvasiai ir nutautėjusių įtakai, išskiriant vieną kitą asmenį;

c) dauguma buvusių tokių karių išoriai valstybei yra lojalūs, bet valstybinio nusistatymo neturi, esamai santvarkai nepilnai palankūs ir lieka neaiškūs;

d) paskelbus mobilizaciją tokie buvusieji kariai ypatingo nerangumo gal ir nerodys, tai tik dèl jiems žinomai gresiančios bausmès, bet kurie galès - slèpsis, pabėgdami už administracijos linijos;

e) iš lenkuojančių šeimų kilę kariai, grịžę i namus, lietuvinimo darbo patys nevaro ir kitiems nepadeda, laikydamiesi pasyviai. Itvairiose lietu-

95 Pasienio baro viršininko 19331219 raštas apskrities komendantui. Ten pat, 1. 483484.

96 Ten pat, 1. 483. 
viškose sueigose: vakaruškose, gegužinėse ir t. p., vartoja lenkų kalbą ir dainuoja lenkiškas daineles ir

f) kiek žinoma, lietuvinimo darbas kariuomenès dalyse /auklejjant lenkuojančius jaunuolius/ gana aukštai pastatytas ir daugiau vargiai ką begalima būtų bepridèti. Lenkuojantis elementas tarnaudamas kariuomenèje kiek susipranta lietuvybès atžvilgiu, bet grị̌z̨s iš kariuomenès ị namus, vèl susiduria namuose su lenkuojančiu elementu ir po ne kurio laiko igytas kariuomenèje žinias pamiršta ir vèl nutautejja, nes kiekvieno tokio kario šeimoje nèra nei vieno lietuviško laikraščio ir naudingos lietuviškos knygos. Būtų gera, kad tokiems grịžtantiems kariams iš kariuomenès ị namus nekuriam laikui veltui būtų užprenumeruojami pigesni lietuviški laikraščiai, kad grižžs karys iš kariuomenès galètų pasiskaityti." ${ }^{\text {"97 }}$

Mokyklų inspektorius Staugaitis rašè, kad kariuomenès poveikis, jo nuomone, yra laikinas: „Kariuomenė per trumpą laiką nutautusi nušlifuoja, bet jis grižzęs [namo] lieka senu vilku. " ${ }^{\text {" }}$

Beižionių kun. S. Rudžionis atsakè, kad „grižęe iš kariuomenès lenkuojantys grịžta prie namų dvasios, prie lietuviško kultūrinio darbo neprisideda" ${ }^{\text {"99 }}$.

Agronomas iš Aukštadvario V. Rimkus 1933 m. gruodžio 19 d. pastebèjo, kad „lenkuojantys grịžę iš kariuomenès sulietuvèja, bet apie $10 \%$ vèl pasiduoda nutautusiųjų itakai ir dvasiai. Naudinga imti ị kariuomenę daugiau šio krašto jaunuolių, bet ten auklèti juos [perduoti] ne grandiniams, puskarininkiams ar viršiloms, kurie neturi takto, juos užgaulioja, o patiems karininkams" ${ }^{100}$.

Aukštadvario bažnyčios klebonas A. Žilinskas 1934 m. sausio 3 d. teigè, kad dèl tarnybos kariuomeneje lenkiškai kalbantieji igyja ir blogų patirčių: „grǐžta iš kariuomenès žymiai sulietuvinti. Tik nusiskundžia mūsų kariškių žiaurumu, dideliu niekinimu lenkuojančių ir jų ịvairiais būdais pašiepimu. Kai grịžę iš kariuomenès pasipasakoja, šeimose kyla didelè užuojauta iškentejjusiems, niekinimas Lietuvos kariuomenès ir visa to, kas lietuviška. Taip lenkuojantys dar labiau savo dvasioj užsispiria" ${ }^{101}$.

\footnotetext{
97 Ten pat, 1. 480-482.

98 Ten pat, 1.478.

99 Ten pat, 1. 462.

100 Ten pat, 1. 460

101 Ten pat, 1. 433.
} 
$1934 \mathrm{~m}$. kovo 2 d. Žaslių pradinès mokyklos vedèjas A. Baumilas Trakų apskrities komendantui teige, kad „lenkuojantis elementas“, grįžęs iš kariuomenès, tautiškai menkai susipratęs, greit pasiduoda buvusiai namų dvasiai. „Lenkuojantị elementą“ kariuomenèje reikètų auklèti daugiau didaktiškai, o ne statutiškai, ịvesti kariuomenès dalių švietimo ir mokymo programose daugiau tèvynès pažinimo dalykų, dažniau skaityti patriotinio turinio paskaitas, kad jie turètų progą i̇sisąmoninti, kas jų bočiai buvo ir kas jie turètų būti. Tokị elementą, grižusị iš kariuomenès, reikètų

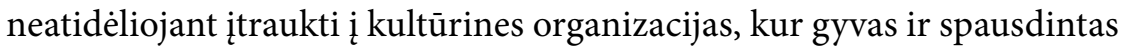
žodis juos „žadintų prie tèvynès pamylëjimo “102.

$1934 \mathrm{~m}$. balandžio $2 \mathrm{~d}$. dr. kun. prelatas Juozas Labukas (Matulaitis) (1894-1979), Kaišiadorių vyskupijos kancleris, teige, jog daug lenkų iš kariuomenès grižta "nepakankamai sulietuvinti“ ar netgi priešiškai nusistatę, ir tam ịtakos turi „kariuomenejje draugų tyčiojimasis iš lenkuojančių“. Šauliams irgi prikiša netaktišką elgesị su sulenkejjusiais, jų pravardžiavimą, taip pat pažymi, kad planingam lietuvinimo darbui trukdo Bažnyčios ir valstybės konfliktas ${ }^{103}$, valstybę sutapatindamas su A. Smetonos valdžia, rašè J. Labukas.

Anot pasienio policijos baro viršininko, iš kariuomenès grį̌žę jaunimas „yra pakankamai sulietuvejęs ir pradžioje stengiasi lietuviškai kalbèti ir savo lietuviškumą pabrèžti, bet daugumas vèl pasiduoda namiškių ịtakai ir vyraujančiai namuose dvasiai, pasidaro indiferentiški ir vartoja lenkų kalbą". Nors iš pradžių didžiuojasi, kad buvo kariai, po metų kitų viską pamiršta. Pasienio policijos vadas siūlo tarnaujančius kariuomenèje auklèti mokant garbingos tautos istorijos, skiepijant tautiškumą, tévynės meilę.

Karo komendantas V. Žutautas nusiunte savo išvadas $1934 \mathrm{~m}$. sausio 25 d. ir II péstininkų divizijos vadui, lydraštyje įrašęs: „Daug ịtakos atlietuvinimui turi kariuomenè, bet po jos grị̌ę vyrai patenka ị tą pačią aplinką ir vèl grižta prie senų papročių. Be to, kariuomenejje viršilos ir puskarininkiai lenkuojančius kartais pašiepia, persekioja, todèl tokių istorijų prisiklausę paskui ir kiti bijo eiti ị kariuomenę."

Auklèjant sulenkẻjusius kariuomenèje reikètų kreipti dèmesị $\mathfrak{x}$ aisčių ir slavų skirtumus, $\mathfrak{i}$ lietuviškus vietovardžius, toponimus, pavardes ir t. t., taip pat ị istoriją - kaip susidarè bajorų luomas (šlèktos), iš kur atsi-

102 Žaslių mokyklos vedèjo A. Baumilo 19340301 atsakymas ị anketą. Ten pat, 1. 383. ${ }^{103}$ J. Labuko atsakymai i anketą. Ten pat, 1. 287-298. 
rado kalbantys lenkiškai ir gudiškai, kada atsirado krikščionybė (kad ne tik lietuviai buvo pagonys iki krikšto, bet ir kitos tautos, taip pat ir lenkai, kol jų čekoslovakai nepakrikštijo).

Baigusius tarnauti kariuomenèje būtina ruošti „kovoti už lietuvybę grịžus ị namus“, kiekvieną išmokyti po keliasdešimt dainų, žaidimų, kad grịžę ì namus galètų kitiems imponuoti, suteikti gyvumo ì pramogoms.

Reikètų instruktuoti pasienio policininkus, kad iš žmonių nesišaipytų: „Jokiu būdu neturètų būti gyventojai pravardžiuojami „lenkais“, "gudais“ - bet nuolat kartojama, apgailestaujama, kad Kęstučio sostinès apylinkès gyventojai ir buvę Lietuvos gynejjai svetimų suvedžioti pamiršo savo tèvų kalbą. Žymi dalis šio krašto gyventojų, tiesa, nemoka lietuvių kalbos, bet jie ir lenkiškai kalbèdami nuoširdžiai pasisako esą lietuviai, kad jie gyvena Lietuvoje ir t. t."

Mokytojas S. Dulke 1933 m. gruodžio 16 d. rašte, atsakydamas i pateiktus klausimus, pageidavo, kad pasienio policijos viršininkai neleistų policininkams „lenkuojančių“ gyventojų pravardžiuoti, vadinti išgamomis, lenkais, gudais ir pan., kas dažnai pasitaiko. Iš Daugirdiškių kaime gyvenančių 7 policininkų tokie yra 2. Pažangesni vietos gyventojai tuo piktinasi: „Juk lietuvi pravardžiuoti lenku - berods didžiausias užgavimas!“104

\section{KARO KOMENDANTO IŠVADOS}

Trakų karo komendantas plk. ltn. V. Žutautas siunčiamos medžiagos lydraštyje Generalinio štabo valdybos II skyriaus viršininkui rašè, kad atsakydamas ị anketos „Mūsų pasienio su lenkais tyrimo reikalu“ klausimus, be surinktų duomenų, pateikè ir savo paties samprotavimus, pabrèždamas, kad tarp respondentų „nuomonių priešingumo beveik nèra. $<\ldots>$ Yra griežtų priešinimų, bet aš palaikiau tą perdètu dalyku ir parinkau vidurị. Anketą, kiek pats sugebu, atskirais klausimais ir dabar dar ir toliau tęsiu“. ${ }^{105}$

\footnotetext{
104 Ten pat, 1. 466

${ }^{105}$ V. Žutauto 19340125 lydraštis. Ten pat, 1. 390. Anketos atsakymo trečias egzempliorius, 19340125 nusiųstas II pėstininkų divizijos vadui. Ten pat, 1. 389.
} 


\section{KARO KOMENDANTO V. ŽUTAUTO PARENGTA TYRIMO SUVESTINE}

\section{Dèl tikros padeties}

Trakų apskrityje palei demarkacijos liniją 25 kilometrų ruože gyvena 7026 ūkininkai, iš jų oficialiai užsirašę lenkais - 17, gudais - 600, rusais 105 , žydais -26 , totoriais - 2 . Visi gyventojai, išskyrus $2-3$ be pilietybès, Lietuvos piliečiai. Iš visų paminètų ūkininkų „griežtai lenkuojantieji ir beveik visai nevartoja lietuvių kalbos“ - apie 20 proc.

Lietuviškai nekalba Žaslių valsčiuje: Korsakų kaime - 40 gyventojų, Benkūnų - 19, Burbiškių - 20, Dainavos - 36, Šešonių - 48, Maskoliškių - 7, Padvarių - 21, Senkonių - 26.

Semeliškių valsčiuje: Beižonių parapijoje iš 2000 gyventojų lenkais užsirašę 282 (pagal 1923 m. statistiką). Nelietuviški punktai - Barboriškių kaimas (buvęs dvaras), Eitulionių kaimas. Pvz., Daugirdiškių kaime iš 106 gyventojų 80 moka lietuviškai. Semeliškių valsčiuje „lenkuojančių“ yra apie 45 proc.

Vievio valsčiuje lietuviškiausi kaimai - Pakalniškių ir Abromiškių. (bendras lenkuojančių skaičius neịrašytas). Onuškio valsčiuje lenkiškai kalbančių - apie 40 proc. Aukštadvario valsčiuje - apie 60 proc.

\section{Vietos gyventoju santykiai su kitos demarkacijos linijos gyventojais}

Sulaikant pereinančius demarkacinę liniją suskaičiuota, kad apie 50 proc. pereina liniją, kad pasimatytų su giminèmis, 30 proc. - kontrabandos tikslais, 20 proc. - kitais tikslais (šnipinejjimo, dokumentų ieškojimo ir t. t.).

Kontrabandininkai iš Lenkijos pusès neša avalynę, audinius, mezginius (batukai ten kainuoja 6-8 Lt, Lietuvoje - $12 \mathrm{Lt}$, skaros ten „kaštuoja“ 2-3 Lt, Lietuvoje - $5 \mathrm{Lt}$ ). Iš Lietuvos pusès neša cukrų, sachariną, tabaką ir t. t. Kartais kontrabandininkai pervedinejja per sieną ne vietinius žmones, yra tokių, kurie eina per sieną tarsi iš azarto („lyg rungtyniaudami“).

Lietuvos propagandai naudingi ekonominiai motyvai, nes anoje pusejje gyventojai „be pinigų ir be darbo“, ten siaučia mokesčių anarchija („žmonès nežino, kiek mokèti (nèra griežtų nuostatų), kada mokèti 
(nuolat reikalauja), už ką mokèti (už viską imama), kam mokèti (visi reikalauja)“; ten brangesnè net druska, nors lenkai jos turi savo (todèl iš Lietuvos ji nešama kaip kontrabanda), iš Lietuvos neša tabaką (Lenkijoje gyventojams draudžiama ji auginti, todèl siūloma netgi organizuoti „mūsų kaimiško tabako“ eksportą).

„Pirmaisiais mūsų nepriklausomybès metais lenkininkai stengèsi patraukti lenkuojančius gyventojus savo pusèn ịvairiais viliojančiais pažadais ir grasinimais: „Lenkai užims Lietuvą ir lups litvomanams skūras“, „Greit ateis Pilsudskis ir pakeis tvarką“ ir t. t. Dabar tokių pažadų ir grasinimo metodas neturi pasisekimo ir bendrai nusekęs. Naujų argumentų agitacijai prieš Lietuvą lyg nesuranda.“

Krizès metu Lietuvoje žymiai geresnè ekonominè padètis, anoje pusėje gyventojai kenčia labai didelị skurdą, apkrauti labai dideliais mokesčiais, kurių išieškojimas labai greitas. Žmonès nemato jokio pagerèjimo. Todèl Lietuvos pusèje gyvenantys žino - „lenkų tvarkos baidosi“, ir yra susidariusi nuomonè, kad Lietuvos „medžiaginè būklè bent trigubai geresnè, lenkų kalba nepersekiojama, buvęs pasiilgimas Varšuvos - dabar išgaravo“.

„Lenkininkais, palaikančiais lenkiškumą, liko moterys, dvarininkai, šlèktos ir kiti lenkiškumą palaikantieji asmenys bei sąmoningi niekšai. Jų motyvai ginti lenkišką kultūrą, kalbą, maldą, giesmę, nepasiduoti „pagoniškai Lietuvai“ ir jos netvarkingų valdininkų įtakai. Šiai agitacijai peno duoda valdininkų ir pareigūnų klaidos, blogas elgesys, nedorovingumas, netvarkingumas, išsišokimai, muštynès, nesugyvenimas su kunigais. Lenkininkai tokius ịvykius išpučia ir išgarsina. Kaip pavyzdžiai minimi pasienio policininkai, kurie tvirkina kaimo merginas, nesilaiko pasninko, nelanko bažnyčios. Kartais minimi ir nedorovingi mokytojai ar mokytojos, „einančios iš proto dèl meilès“.

Daug ịtakos atlietuvinimui turi kariuomene, bet po jos grịžę vyrai patenka ị tą pačią aplinką ir vèl grị̌ta prie senų papročių. Be to, kariuomenèje viršilos ir puskarininkiai „lenkuojančius“ kartais pašiepia, persekioja, todèl tokių istorijų prisiklausę paskui ir kiti bijo eiti ị kariuomenę.

Lenkų redakcijos savo prenumeratoriams siunčia ne po vieną, bet po 5 ar 10 egz. (platinimui), be to, lenkiškų knygų jie gauna iš dvarų ar „skrajojančių“ knygynų.

I lietuviškas organizacijas „lenkuojantieji“ nesirašo (vengia giminių ir kaimo pašaipos, be to, ir organizacijos ne visada turi gerą vardą). 
Vietiniai nukentèjo ir nuo ekonominių organizacijų bankrotų (kooperatyvų, pieninių ir t. t.), todèl jų bijo iš tolo. Tiesą sakant, jų vengia ir lietuviai, palikdami organizacijas ,valdininkams, mokytojams ir pareigūnams“.

I Šaulių sąungą vietiniai žiūri kaip ì partizanus, kurie iš jų atminties dar neišdilo, nes „,neutraliai zonai esant partizanai gyventojams buvo daug žalos padarę". Bailesni vietiniai nestoja ị šaulius ir dèl to, kad prasidejus karui jie „pirmon eilèn bus paimti ị kautynes“.

Žmonių baimes rodo ir tai, kad $1932 \mathrm{~m}$. Žemès ùkio rūmams per apskričiu agronomus dalinant nemokamai pagerintą javų sèklą, jie net nesusirinkdavo. Mat bijojo, kad, paėmus sẻklos, valdžia juos ịrašys ị kokią nors draugiją. Po ilgų aiškinimų kitais metais atsirado tiek norinčiųjų, „kad atsikratyti buvo sunku“.

I Šaulių sąjungą daugiausia stoja valdininkai ir pareigūnai, tie ūkininkai, kurie nori gauti leidimą ginklą laikyti, dèl uniformos, šaudymo ir pan.

Yra keli šaulių būriai kaimuose, kur ūkininkai sudaro daugumą ir kur apylinkès žmonès juos palaiko (Žilinų, Dusmenų, Antokolio ir Kaniūkų), taip pat lietuviškose apylinkèse. Žiežmarių ir Žaslių valsčiuose tarp šaulių daugiausia ūkininkai. Apylinkių gyventojai palankūs ir Darsūniškio, Užuguosčio, Beižonių, Kietaviškių, Paparčuu, Palomenès būriams. Tačiau „šauliams neprijaučia“, todèl ir ūkininkų mažai Onuškio, Aukštadvario, Semeliškių, Vievio valsčių būriuose.

Auklejjant sulenkejjusius kariuomenèje reikètų atkreipti dèmesị $\mathfrak{i}$ aisčiu ir slavų skirtumus, $\mathfrak{i}$ lietuviškus vietovardžius, toponimus, pavardes, taip pat ị istoriją - kaip susidare bajorų luomas (šlèktos), iš kur atsirado kalbantys lenkiškai ir gudiškai, kada atsirado krikščionybė (kad ne tik lietuviai buvo pagonys iki krikšto, bet ir kitos tautos, tarp jų - lenkai, kol jų čekoslovakai nepakrikštijo).

„Lenkuojantys" savo pasilinksminimų beveik nerengia, nuobodžiauja, todèl gausiai lanko lietuvių renginius, bet jų tikslas yra ne lietuvių kalbos pasiklausyti, o pasilinksminti, pamerginti. Pramogas rengia mokyklos, šauliai, valdininkai ${ }^{106}$.

Mokyklos šio krašto lietuvinimui daug padarè ir dar daug daugiau gali padaryti, nes "yra mokyklų, ị kurias tèvai vaikus siunčia pralenkdami arčiau esančias mokyklas, nes artimesnès neturi gero vardo, nepatinka“.

106 Ten pat, 1. 397. 
Pradžios mokyklų tinklas palei demarkacinę liniją gan tankus. Dalis jų ìsikūrusios net moderniuose rūmuose. Bet mokytojai $\mathfrak{i}$ jas skiriami neatsižvelgiant ị sąlygas (kad gyventojai nekalba lietuviškai, negerbia nesilaikančiųjų religinių reikalavimų, gyvena vargingai ir nemėgsta mokytojų, kurios „frantina“ brangiais rūbais ir pan.).

I šị regioną (kur blogas susisiekimas su centru, teatrais ir kinais) mokytojai siųsti kaip ị tremtị. Pastebimas kai kurių tingumas ar net opozicija, kai kurie užsièmè kontrabanda (tiesa, daugiau Musninkų valsčiuje): „I ši kraštą, kur ruošiamos kultūrinès bangos Vilniaus kraštui užtvinti, reikalinga skirti gabiausius, sveikiausius, linksmiausius, rimčiausius, uoliausius mokytojus. Prie to dar ir tikinčius, ir lankančius bažnyčią. "Čia mokytojai turi būti ir kalbininkai, ir psichologai.

Mokytojai visa tai žino ir vengia šio krašto, nes čia darbo sąlygos sunkios („nepatogus susisiekimas, baido gyventojų nekultūringumas, maisto produktų ìsigijimo sunkumas ir pan.“), todèl būtina suprasti darbo idejos kilnumą („Vilnijos klausimas“). Čia vietiniai žmonès nedaug ką turi parduoti, bet jei turi - kainas lygina pagal Kauną.

Tarp atsidavusių šiam darbui minimi mokytojai Buinevičius ir Kastantinavičienè, dirbantys Vievyje, Čiurinskas - Aleksandriškèse, Šiaučiūnas - Kernavèje, Smolskaitė - Kazokiškyje, Kaluževičienè - Vaitkūnuose, Rajeckaitè - Žikaronyse ir kt. Tačiau yra ir tokių, „kurie, sąžiningai atlikę pamokų valandas, nieku daugiau nesidomina ir laikosi nuošaliai nuo kaimo tamsuolių lyg ponas“.

Trakų apskrityje anksčiau veikẻ liaudies universitetai, bet kai už paskaitas nebebuvo mokama, sunyko. Žmones traukẻ ne tiek pačios paskaitos, kiek po jų buvę šokiai ir „filmos“. Anksčiau čia dirbantys mokytojai gaudavo ir specialius priedus, bet jų neliko. Pritraukti „lenkuojančių“ $i$ chorus, teatrus ar sportą nepavyksta.

Didelę žalą daro mokytojų ir klebonų nesugyvenimas: „Daug yra klebonų, kurie sudarė priežastis mokytojams atsigrị̌ti nuo klebonų, bet yra ir mokytojų, dèl kurių elgesio klebonai atsigrįžo nuo mokytojų. Priežastys tam nesugyvenimui labai įvairios, nestokoja intrigų, pataikavimų ir bailumo“.

Būna, kad „lenkuojantys“ tèvai atima iš vaikų lietuviškas maldaknyges, sudrasko, sudegina ar ịkalbinejja neklausyti mokytojų pasakojimų lietuvių kalba, nesimokyti lietuviškų poterių, kliudo lankyti mokyklą: „Geriems 
pradž[ios] mokykl[os] mokytojams reikia duoti ir pasitikèjimo, nes tik jo nevaržomas bendravimas su žmonėmis, su vietiniais inteligentiškais asmenimis gali laiduoti jiems naudingą įtakos galimybę, informaciją bei susivokimą. Tie mokytojai, kurie bendrauja, vaikščioja pas kitus ir pas save priima svečius, tie turi priemones lenkiškumo „,ienoms“ ardyti ir griauti.“

Pastebèta, kad šių apylinkių žmonès ,jokio politinio nusistatymo ir grupavimosi neturi; nereiškia net noro, vienintelè rūšis draugijų - tikybinè. Ir per tą organizaciją tik ir galima veikti. Skautų, Šaulių sąjungos ir kitu jie nesupranta ir bijo“.

Kalbama ir apie vietinių žmonių misticizmą, kuris pasireiškia dainų, istorijų, pasakų, padavimų apie senovės žygius ir milžinus pomėgiu „štai kurio peno reiktų jiems nepasigailèti“.

Rašoma, kad mokytojai, bendraudami su dvarininkais ir sąmoningais „lenkininkais“, neturètų pasiduoti jų lipšnumui, kuris dažnai vartojamas ir pasireiškia „laba diena, kaip gyvuojat“, o paskui „przeprašam, gal sutiksite kalbèti lenkiškai arba rusiškai“. Tokiu atveju mokytojai turètų nusistatyti kalbèti tik lietuviškai.

Mokytojai neturètų vesti lenkių arba „lenkuojančių“, nes „nei teoretiškai, nei praktiškai jos nepasiduoda lietuvių dvasiai ir nesusilaiko nuo lenkų kalbos net ten, kur jokio pagrindo taip kalbèti nèra“.

Komendanto atsakyme analizuojama, kas geriau šiam kraštui - mokytojai vyrai ar moterys. Kiek labiau linkstama, kad tinkamesni vyrai („tinka sunkiam darbui, sportui, geriau sugeba apsiginti ir reaguoti ivykiams ir pasikèsinimams ir beveik apsaugoti nuo „jsimylëjimo scenų“), o moteris galima skirti ten, kur yra ir kitų mokytojų (,ypatingas reikalas prie mokytojų moterų atsiranda tada, kada rengiama vaidinimai, chorai ir pan.").

Dèl Bažnyčios. Oficialiai kunigai parapijiečių i „,geruosius“ ir „,bloguosius" pagal kalbą neskirsto, tačiau daugiau ar mažiau prisideda prie krašto lietuvinimo. Minimi veiklesni kunigai kaip kun. N. Švogžlys Kernavejje, kun. S. Rudžionis Beižionyse, kun. Mincevičius Vievyje, kun. Pupaleigis Gegužinèje, Užuguosčio klebonas ir kiti. Kai kurie jų dalyvauja ir Šaulių, Skautų organizacijų veikloje. Išskiriamas ir kun. Slavynas (Kaišiadorių vidurinès mokyklos kapelionas), kuris „dirba Valdžios ir Bažnyčios taikos idejjai, tarpininkaudamas ir švelnindamas santykius vietinių kunigų su valdininkais“.

O kai kurie senesni kunigai pagal tradiciją yra pripratę prie lenkų kal- 
bos ir ją laiko lygiaverte arba netgi kiek iškelia aukščiau. Tokie yra Aukštadvario klebonas kun. Paškonis, Semeliškių klebonas ir kiti. Neigiamai ị lietuvinimo akcijas žiūri Dusmenų klebonas kun. Smolenskis (lenkas), Širvintose - kun. Juraitis.

Onuškio bažnyčioje pamokslai ir giesmès - tik lietuviškai. Aukštadvario - lietuviškai du šventadienius, lenkiškai - vieną. Semeliškèse kas sekmadienị pamokslai sakomi ir lietuviškai, ir lenkiškai. Vievyje ir Kazokiškyje - pakaitomis lietuviškai ir lenkiškai, Beižonyse - vien lietuviškai, Kaišiadoryse - taip pat vien lietuviškai ${ }^{107}$, tačiau per metines šventes (Kalèdas ir Velykas) koplyčioje laikomos pamaldos lenkų kalba.

Anksčiau buvo daug kunigų veiklos, nukreiptos prieš valdžią, vyriausybę, bet dabar to jau beveik nèra. Jei pasitaiko - kreipiamasi į vyskupą, kad nesusipratimų tarp kunigų ir valdininkų nekiltų. Žinoma, tai priklauso nuo vyskupo geranoriškumo. „Kunigai žinodami vietinių žmonių psichologiją anksčiau sąmoningai stengdavosi išvesti vietos valdininkus iš lygsvaros, kad tie pasikarščiavę padarytų žygi ar veiksmą, padarantị kunigą „kankiniu“, „persekiojimų auka“ir t. t. (buvo atsitikimas Žiežmariuose). Kiti kunigai, gavę iš teismo pinigines pabaudas, atsisakinėdavo jas mokèti ir ateidavo ị nuovadas pasisiūlydami, kad būtų suimti ir siunčiami ị kalejjimus kalèti. Dabar tokių šposų jau nesikartoja.“

Kunigai labiausiai bijo, kad nebūtų izoliuoti nuo jaunimo (skautų) dèl gandų apie civilinę metrikaciją. Vykdyti Krikščionių demokratų partijos politikos jie neturi tikslo ${ }^{108}$.

Trakų apskrityje „lenkuojančių“ žmonių, patekusių i savivaldybes, nèra. „Jei kur ir buvo bandoma pravesti, tai jie negavo tvirtinimo ir perrinkus tapo pakeisti. Taip bent paviršutiniškai dalykas atrodo. Šio krašto žmonès sugeba sklandžiai veidmainiauti, todèl ì gyventojų sielą žvilgterèti sunku." Pasuose lenkais užsirašo tik tie, kuriems nereikia valdžios paramos ir kurie jaučia, kad tai jiems nepakenks. „Silpnesnieji duodasi užrašyti lietuviais, bet dvasioje tūlas pasilieka lenkuojančiu ir kai

\footnotetext{
${ }^{107}$ Kaišiadoriečių atsiminimuose teigiama, kad lenkiškos pamaldos Kaišiadoryse nutrūko 1930 m., minint Vytauto Didžiojo metus. Mat tą dieną, švenčiant Vytauto Didžiojo jubiliejų, pagal eilę turejjo būti lenkiškos pamaldos, tačiau dèl šventès nacionalinio patoso lenkiškos pamaldos buvo pakeistos lietuviškomis. Po to pakaitomis laikomų lenkiškų pamaldų tradicija Kaišiadoryse išnyko (aut. past.).

108 Ten pat, 1. 398-402.
} 
kuris net aršesnis už atvirai pasisakantị „lenku“. Patekęs i savivaldybès organus lenkuojantis elementas rodo valstybinio nusistatymo, nes iš to dalyvavimo mato asmeninès naudos arba turi noro patarnauti lenkuojančių interesams. Čia kaip tik ir reiškiasi kai kurių anketoje dalyvavusių asmenų pastebètas ir spėjamas gyventojų veidmainiavimas: „neužsirašęs lietuviu, - sako lenkininkai, - su pagonimis nesugyvensi."

Buvo atvejų, kai žmonès norèjo pasuose užsirašyti lenkais (Kernavejje -20 , Aukštadvaryje $-2-3$, Gegužinèje -1$)^{109}$. Išduodanti pasus vietos savivaldybė „stengiasi užrašyti pase taip, su kuo dalis gyventojų nenori susigyventi. Todèl pasitaiko, kad paklaustas, kas esi - lietuvis ar lenkas? - atsako: pase užrašytas taip ir taip“. „Atrodytų, kad suagituotus tamsuolius, nieko nenusimanančius tautos istorijoje ir (vien tik dèl keliasdešimt metų atgal primestos jiems svetimos kalbos) ir šiandieną nemokančius tikrosios kalbos užrašyti svetimtaučiais negalima. Taip užrašytas jis bus skatinamas ir net verčiamas eiti ị svetimųjų glèbị. Bet ir lietuviu pažymint, tam reikia išgauti žmogaus sutikimą. Reikia, kad apsišvietęs, kantrus valdininkas ittikintų jị arba bent mandagiai, jautriai jam nusakytų, kad jis yra svetimo gaivalo suklaidintas ir kad jam kada nors netektų gailètis klaidos (jei užsirašytų svetimtaučiu) bei, kad apsaugoti jị nuo svetimụjų mulkinimo, šikart yra užrašomas lietuviu; jei kada vèliau bus perrašomas ir norès - galès būti užrašytas kitaip. Užrašymas lietuviais, apskritai imant, turi daug praktiškos reikšmès (pav., mokyklu klausimas), kas spiriasi būtinai užsirašyti „lenku“, „gudu“, turètų dokumentais įrodyti savo lenkiškumą arba gudišką kilmę.“

Apskrities viršininko žinioje esančioms įstaigoms buvo nurodyta, kad „jstaigose būtų palaikoma lietuviškumas ir lietuvių kalba. Kitaip kalbèti su interesantais galima tik tada, kai senukas interesantas lietuvių kalbos tikrai nemoka“.

Siūlyta, jei tarnauja „valstybinėse įstaigose, o namuose ar viešai kalba lenkiškai, vokiškai ar gudiškai, kenkia krašto lietuvinimo darbui ir juos reikètų nukelti ị grynai susipratusių lietuvių sritis. I jų vietas reiktų siųsti energingus, sąžiningus, dorovingus, blaivius, patriotus lietuvius“.

Reikètų instruktuoti pasienio policininkus, nes dabar jų ịprotis už-

${ }^{109}$ Iniciatyva pakeisti pase nurodytą tautybę iš lietuvio ị lenko kilo 1927 m. pradžioje, kai naujoji Lietuvos vyriausybė, išlaikanti lenkiškas mokyklas, iš mokinių tėvų pareikalavo įrodymų, kad jie yra lenkai. Toks judejimas pastebètas, pavyzdžiui, Žaslių valsčiuje. 
gaulioti, pravardžiuoti ir pašiepti yra kenksmingas. Tinkamai instruktuoti vietos valdininkai ir pareigūnai (policininkai, eiguliai, paštininkai, savivaldybių tarnautojai, šauliai ir kiti) galètų aiškinti gyventojams lietuvišką vietovardžių, pavardžių, kalbos žargono kilmę, bet jokiu būdu ne persekiodami ir pravardžiuodami.

Trakų V šaulių rinktinès vadas, dar naujas žmogus, atvykęs ị rinktinę, pamate ją „demoralizuotą, pakrikusią ir pairusią“, todèl dabar „energingai veda restauracijos, pertvarkymo, valymo bei stiprinimo darbą“. Buvęs rinktinès vadas savo pareigomis nesidomejo, o ir netinkamu elgesiu prisidejo prie jos smukimo.

Šaulių veiklai sąlygos nebuvo lengvos, nes „kraštas vargingas, krašto gyventojai nesusipratę, o kai kur priešingai nusistatę lietuviškumui ir bi kokioms organizacijoms ir draugijoms, tas neduoda galimybės kaimo jaunimą ịtraukti ị būrius“. Todèl daugelis šaulių buvo ne kaimo žmonès. Be to, šauliai neturejjo kur rinktis - savo namų, kur galètų atidaryti skaityklas, bibliotekas, rengti vaidinimus, susirinkimus, burti chorą. Beliko šaudymo pratybos.

Kad žmogų priimtų ị šaulius, ji turëjo rekomenduoti du seni Šaulių sąjungos nariai. Kandidato prašymą priima būrio valdyba, tada rinktinès vadas tarpininkauja centro valdyboje. Kadangi netgi ir tokiu būdu priimant naujus narius įsiskverbdavo „negeistinų“ asmenų, Trakų apskrities kandidatai buvo tikrinami ir saugumo policijos. Taip pat buvo tikrinami ir norintys gauti leidimą laikyti ginklą. Šauliai rengè vakarèlius, gegužines, valstybinių švenčių minëjimus, paskaitas, dalyvavo manevruose, bet tai daugiausia vyko pačių būrių, o ne rinktinès iniciatyva. „Lenkuojantys" savo vaikams sakè: "I šaulius rašosi tie, kas nori laisvai šaudinėti.“ Reikètų suprasti - nori šauliais tapti tie, kurie linkę savavaliauti, be tikslo ir nekontroliuojami šaudyti.

Be Šaulių sąungos, buvo Lietuvių tautininkų sąjunga, jaunalietuviai, VVS, tikybinès organizacijos (kuriose daugiausia dalyvavo moterys, bet jos lietuvinimo darbo nedaug dirbo). „Privačių asmenų šiame darbe veikimo nèra, nes tų asmenų mažai čia yra, jie darbe neiškilo. " 110

Lenkiško elemento reakcijos būdai ir lizdai menki, nes Trakų apskrityje nèra nei valdiškų, nei visuomeninių lenkiškų mokyklų. Vievyje ịsteigta Gudų draugija siekè ten jkurti gudų mokyklą (Mitrofanovas rinko pa-

110 Ten pat, 1. 404-405. 
rašus). Byla dar Švietimo ministerijoje. „Yra rimtų nurodymų, kad gudų draugija yra širma lenkų akcijos branduoliui. Ton draugijon dažnai lankosi iš Kauno lenkų gimnazijos mokytojai ir direkt. Abramavičius."

Lenkinimo dvasia palaikoma dvarų (darbininkams dalijami laikraščiai, knygos). Yra iš Kauno lenkų knygynų atsigabenančių Varšuvoje išleistų knygelių ir organizuojančių „skrajojančius knygynèlius“ (minimas Vievio valsčiuje, Zabarijos kaime, gyvenantis Vaicechauskas). Labiausiai tarp gyventojų paplitęs laikraštis - „Chata Rodzinna“, kuri gauna netgi jo neprenumeruojantys. Siunčiama daugiau egzempliorių ir po to jie eina per rankas.

Lietuviams irgi reikètų turèti knygynèlių. Bet iškart duoti patriotinę knygą negalima, „pradžioje reikia ji pripratinti prie lietuvių kalbos, neįtralèmis, grožio literatūros, pasakų rinkiniu ir pan. knygomis ir tik matant prisirišimą - duoti patriotinių knygų“.

Lenkai bando veikti ir per smulkaus kredito draugijas. Pavyzdžiui, pernai jie bande „okupuoti Aukštadvario smulkaus kredito dr-ją“. Mat Lietuvos bankai duoda pinigų draugijoms su 9-9,5 proc. palūkanomis, tuomet pačios draugijos skolina ūkininkams su 12 proc. palūkanomis. O Kauno lenkų bankas Aukštadvario draugijai pasiūlè paskolą su 7 proc. palūkanomis (nors Kaune lenkų smulkaus kredito bankas pats skolina nustatęs 10-12 proc. palūkanas), bet su sąlyga, kad grąžins pinigus Lietuvos bankams. Tačiau to neleido padaryti Lietuvos banko Trakų skyriaus direktorius. Idomu, kad lenkai skolina, iki „pan Pilsudski przyjdzie“"111.

\section{ANKETOS IŠVADOSE PATEIKTOS TRAKŲ KARO KOMENDANTO REKOMENDACIJOS ${ }^{112}$}

Siųsti ị šias sritis lietuviškos kronikos filmus, parodyti krašto gyvenimą, ūkio pažangą, krašto vyresnybę ir t. t. Negailèti pafrontès gyventojams pasakų rinkinèlių, maldaknygių.

Iš 200 apskrities mokytojų Šaulių organizacijoje dalyvauja „vos 62“. Atitarnavusius kariuomenèje reikia ruošti „kovoti už lietuvybę“, kiekvie-

\footnotetext{
111 „Kol ateis ponas Pilsudskis“. Ten pat, 1. 406.

112 Ten pat, 1. 408.
} 
ną išmokyti po keliasdešimt dainų, žaidimų, kad grịžę ỉ namus galètų kitiems imponuoti ${ }^{113}$.

Pageidautina gerinti susisiekimą, nes, pavyzdžiui, norint iš Onuškio pristatyti bekonus iki Vievio ar Kaišiadorių geležinkelio stoties, tenka važiuoti apie 50 kilometrų. Reikia geležinkelio arba plento, remti ūkininkus perkant iš jų produkciją, šiaudus, akmenis. Bekonai priimami tik Kaišiadoryse pirmadieniais ir penktadieniais, bet būtų gerai, kad kurią dieną priimtų ir Vievyje.

Raginti vasarotojus vykti poilsiauti ị pafrontę, rengti čia ekskursijas ${ }^{114}$. Aukštesnieji valdininkai turètų lankytis provincijos miesteliuose, dalyvauti iškilmèse, nes yra tokių vietų, kur „nuo 1918 m. vasario 16 d., sako, nieko, apart nuovados viršininko, nèra matę "115.

Nelietuvius valdininkus reikètų iš šio rajono iškelti, o nedorovingai ir netvarkingai gyvenančius valdininkus, mokytojus ir pareigūnus įspèti ir sudrausti. Reikalauti iš administracijos organų, kad lietuvinimo darbą dirbtų subtiliau, daugiau aiškindami, o ne niekindami. Ispèti be reikalo nevartoti lenkų ir gudų kalbų.

Daug nepatikimų asmenų yra tarp eigulių, nors ši tarnyba turi strateginę reikšmę $e^{116}$.

Pagerbti spaudoje ar kitaip „gerai nusiteikusius kunigus“, leisti laisviau veikti jiems pradžios mokyklose. Lankantis provincijoje valdininkams aplankyti klebonus, nes jie tai laiko garbe ir yra pripratę nuo senų laikų. Vengimas pasimatyti su jais laikomas nepasitikejjimu.

Mokyklose ar visuomeninèse organizacijose organizuojamiems rinkimams reikètų geriau pasirengti, kad paskui netektų netinkamų išrinktųjų tvirtinti. Valdininkai pamaldose turètų dalyvauti dažniau, ne tik per valstybines šventes ${ }^{117}$.

\footnotetext{
113 Ten pat, 1. 408.

114 Ten pat, 1. 410 .

115 Ten pat, 1. 412.

116 Ten pat, 1. 413.

117 Ten pat, 1. 414.
} 


\section{Apskrityje gaunama laikraščių}

Kaišiadorys: lietuvišku - 795, lenkiškų - 38, kitų (kitomis kalbomis) 2; Aukštadvaris: lietuviškų - 93, lenkiškų - 28, kitų - 0; Darsūniškis: lietuviškų - 212, lenkiškų - 0, kitų - 3; Gegužinè: lietuviškų - 189, lenkiškų -17, kitų - 0; Kietaviškis: lietuviškų - 217, lenkiškų - 8, kitų - 0; Kruonis: lietuviškų - 348, lenkišku - 15, kitų - 2; Onuškis: lietuviškų - 183, lenkiškų 39, kitų - 6; Semeliškès: lietuviškų - 269, lenkiškų - 36, kitu - 0; Žasliai: lietuviškų - 434, lenkiškų - 38, kitų - 6; Žiežmariai: lietuviškų - 587, lenkiškų - 29, kitų - 2; Vievis: lietuviškų - 492, lenkiškų - 73, kitų - 0 .

Pašto agentūrose: Beižonys: lietuviškų - 72, lenkiškų - 12, kitų - 0; Čiobiškis: lietuviškų - 166, lenkišku - 2, kitų - 0; Dusmenys: lietuviškų 151, lenkiškų - 9, kitų - 0; Kalviai: lietuviškų - 114, lenkiškų - 2, kitų - 1; Kazokiškès: lietuviškų - 57, lenkiškų - 24, kitu - 0; Palomenè: lietuviškų - 60, lenkiškuc - 7, kitų - 0; Pamieris: lietuviškų - 105, lenkiškų - 14, kitų - 0; Paparčiai: lietuviškų - 98, lenkiškų - 2, kitų - 0; Žaslių gelžk. stotis: lietuviškų -88 , lenkiškų -4 , kitų -2 ; Žilinai: lietuviškų - 174, lenkiškų - 12, kitų - $1^{118}$.

Komendantas V. Žutautas pabrèžè, kad gyventojų lietuvinimui daug ịtakos turi kariuomenè, bet iš jos grižę vyrai patenka ị tą pačią aplinką ir vèl laikosi senų papročių. Be to, kariuomeneje viršilos ir puskarininkiai „lenkuojančius“ kartais pašiepia, persekioja, todèl tokių istorijų prisiklausę paskui ir kiti bijo eiti tarnauti. Reikètų tinkamai instruktuoti pasienio policininkus, nes dabar jų „vartojamas užgauliojimo, pravardžiavimo ir pašiepimo metodas" yra kenksmingas: „Jokiu būdu neturètų būti gyventojai pravardžiuojami „lenkais“, „gudais“ - bet nuolat kartojama, apgailestaujama, kad jie pamiršo savo tèvų kalbą." Žymi dalis šio krašto gyventojų, tiesa, nemoka lietuvių kalbos, bet jie ir lenkiškai kalbẻdami nuoširdžiai pasisako esą lietuviai, kad jie gyvena Lietuvoje. Baigusius tarnauti kariuomenejje reikia ruošti „kovoti už lietuvybę grižus i namus“, kiekvieną išmokyti po keliasdešimt dainų, žaidimų, kad namie galètų kitiems imponuoti, inešti gyvumo i̇ pramogas ${ }^{119}$.

$1934 \mathrm{~m}$. sausio $29 \mathrm{~d}$. Trakų apskrities karo komendantui plk. ltn. Vladui Žutautui už atsiųstą tyrimą raštu padèkojo kariuomenès Vyriausiojo

\footnotetext{
118 Ten pat, 1. 415. Greičiausiai tai 1933 m. žinios.

119 Ten pat, 1. 389-399.
} 
štabo II skyriaus viršininkas plk. Juozas Lanskoronskis: „Tamstos patiekta medžiaga yra rimtai ir planingai sudorota ir turi didelès vertès studijoms ir praktiškoms išvadoms daryti. “120

Surinktą medžiagą V. Žutautas $1934 \mathrm{~m}$. sausio 25 d. taip pat nusiuntė I ir II péstininkų divizijų vadams, o numanydamas, jog tyrimas vertingas, - ir Prezidentūrai.

$1934 \mathrm{~m}$. liepos $4 \mathrm{~d}$. jis gavo prezidento A. Smetonos adjutanto mjr. Tado Šakmano, kuris buvo maloniai nustebintas V. Žutauto medžiaga, „kur taip vaizdžiai parodomas Trakų apskrities atsilikimo vaizdas, laišką. „Tamsta iškeli be galo gražią mintị - atsilikusius kaimus nemokamai aprūpinti laikraščiais. Man rodosi, kad Tamstos sumanymas ras reikalingo atgarsio. Visas šis reikalas dabar yra pavestas tvarkyti p. [V.] Rasteniui, tautininkų S-gos gener. sekretoriui. Jam lengviau negu kam kitam bus susitarti su laikraščių redakcijomis. Tamstos raštas ir žinios taip pat jam persiųstos." ${ }^{121}$

\section{IŠVADOS}

Ši Trakų apskrities gyventojų vartojamos kalbos ir kitų polinkių tyrimo medžiaga (kadangi laiškus su anketomis gavo Utenos, Ukmergès, Trakų, Alytaus, Marijampolès ir Vilkaviškio apskričių karo komendantai, tolesnis istorikų uždavinys būtų rasti tyrimų, atliktų šiose Lietuvos apskrityse, duomenis (pabraukta aut.), atskleidžia įdomią šalies valdžios, kariuomenès ir švietimo ịstaigų, katalikų kunigų ir visuomeninių organizacijų pastangų lietuvinti lenkiškai kalbančius gyventojus panoramą. Akivaizdu, jog karinès vadovybės, parengusios klausimyną, lietuvių kunigų, mokytojų, paštininkų, saugumo ir policijos valdininkų lenkiškai kalbantys vietos gyventojai nebuvo laikomi lenkais, o vadinami ir suvokiami tik kaip „lenkuojantys“, t. y. seniau buvę lietuviai, bet paskui peremę lenkų kalbą. Remiantis šia logika, „lenkuojantys“ turèjo kada nors „atlietuvėti“.

\footnotetext{
${ }^{120}$ Generalinio štabo plk. J. Lanskoronskio 19340129 raštas Trakų apskrities komendantui. Ten pat, 1. 388 .

121 T. Šakmano 19340704 laiškas pulkininkui V. Žutautui. Ten pat, 1. 274.
} 
Atsakymai $\mathfrak{i}$ anketos klausimus pirmiausia atskleidžia nelengvas socialines šio krašto gyventojų gyvenimo sąlygas ir dèl prastos finansinès situacijos spaudinių lietuvių kalba kaimuose trūkumą. Akivaizdu, kad netgi autoritarinio režimo sąlygomis „atlietuvinimo“ (kaip tai buvo suprantama) veikla, siekiant gyventojus integruoti ir išmokyti lietuvių kalbos, nebuvo koordinuojama (pabraukta aut.) šalies karinių, vidaus ir pasienio policijos, švietimo sistemos ịstaigų, visuomeninių organizacijų ir Katalikų bažnyčios, todèl kiekviena organizacija tai darè individualiai. Norèta greito rezultato, tad nesisekant büta visko: lietuvybè platinta per skubejjimą iškreiptomis formomis (neretai tyčiotasi iš lenkakalbių kariuomeneje, tai darè ir policininkai, ir šauliai). Nepaisant tokio žalingo elgesio, gyventojų tautinè ir pilietinè savimonè keitèsi Lietuvos naudai.

Respondentai pažymëjo, jog "lenkuojančiųjų“ namuose dažniausia kalbama lenkiškai, net ir pramokę kariuomenèje lietuvių kalbos jaunuoliai, grižę i namus, toliau kalba lenkiškai, ị lietuvių organizacijas nestoja, nors ir laiko save Lietuvos gyventojais. Tačiau Kaišiadoryse ir kituose Trakų apskrities miesteliuose vis daugiau gyventojų viešai kalba lietuviškai. Daugelis jų save vadina lietuviais, nebesidairo ị Lenkijos pusę, kurioje ekonominè padètis prastesne, nes tai žmonèms buvo labai svarbus veiksnys. Be to, Lietuvos puseje nebuvo tokios įkyrios gyventojų kontrolès, kaip už Lenkijos administracinès linijos.

Pradinių mokyklų tinklas buvo tankus ir patikimai išplètotas ir apèmè lenkiškai kalbančiujų kaimus ir vienkiemius, o valsčiuose vis daugiau steigta lietuviškų pradinių mokyklų. Renginių ir pastangų lyg ir netrūko - štai Trakų apskrities II mokyklų rajono (pasienio), sukurto dèl tam tikrų aplinkybių (ne tik kalbos skirtumų, bet ir ekonominio atsilikimo, nes buvo ir atskiras agronomas; dèl geografinio nutolimo nuo apskrities centro; be to, tai galèjo būti ir tiesiog dèl labai išsiplètusio ịstaigų tinklo, nes šis mokyklų rajonas buvo ịkurtas ịvedant privalomąji švietimą 1931 m., kai bendras pradžios mokyklų mokytojų skaičius apskrityje pasiekè beveik 200), valsčiu pradžios mokyklų kultūrinis veikimas 1933 m. iki balandžio $1 \mathrm{~d}$. tikrai buvo intensyvus - 44 mokyklos surengè 533 susirinkimus ir daug kitų renginiu (juose dalyvavo apie 37000 gyventojų) ${ }^{122}$.

${ }^{122}$ Lentelè, kurią sudare pradinių mokyklų inspektorius. Ten pat, 1. 332. 
Patriotiškai nusiteikusių kunigu pastangomis ir darbu pasiekta, kad daugelis krašto parapijų jau buvo lietuviškos, kunigai siūle pamaldas lenkų kalba ịvesti palaipsniui, skubejjimu lietuvinti nesuerzinti gyventojų. Tose parapijose, kur prieš 10 metų visos pamaldos buvo lenkiškos, „jau nebeliko bažnyčioje nieko lenkiška“, tačiau pripažįstama, kad tai reikejo daryti kuo taktiškiau, deja, skubėta, nes „patriotams norisi labai greitai, kad su efektu" "123. O džiūgavimas pasiektais administraciniais laiméjimais spaudoje pakenkdavo lietuviams Lenkijos pusejje - Vilnijos krašte.

Atsakymai į anketos klausimus rodo, jog ir kaimuose tautininkų režimas patyrè rimtą koliziją dèl krikščionių demokratų nuostatų - tautininkai kèlè kunigų nepasitenkinimą, katalikiškas organizacijas palaikiusių konservatyvių kunigų ir mokytojų santykiai buvo įtempti, nes jie buvo tautininkai arba daugiausia laicistinių pažiūrų.

Akivaizdu ir tai, jog tam tikras Lietuvos administracijos ir jos sukarintų struktūrų spaudimas sumažino dalies „lenkuojančiųjų“ norą „užsirašyti“ lenkais ir lenkiškumą deklaruoti. Klausimyno respondentams buvo aišku, kad geresnè Lietuvos ekonominė padètis, palyginti su prastesne Vilnijos padètimi, turèjo didelę ittaką tam, kad ir lenkiškai kalbantys gyventojai laikè save lietuviais, nebesiorientavo ị Lenkiją ir nieko gero nesitikejo iš valdžios pasikeitimo.

Trakų karo komendanto plk. Vlado Žutauto surinkta medžiaga parodé, jog etninè krašto gyventojų savimonè buvo veikiama naujų vejjų, Lietuvos valstybès, kariuomenès ir savivaldybių veiksmų, todèl kokios nors antivalstybinès lenkiškai kalbančiųjų akcijos pavojaus Lietuvai ar jos kariuomenei nekèlè.

Krašte nepastebèta priešiškos Lietuvai veiklos, nors kai kurie konservatyvūs respondentai net lenkišką kultūrinę veiklą ar lenkiškos spaudos platinimą laikè antilietuviškumo apraiškomis. Nematydamas realių pavojų, karo komendantas V. Žutautas nesiūlè radikalių lituanizacijos priemonių,

123 Ten pat, 1. 287-298. 
tiesiog rekomendavo visiems paprasčiausiai geriau dirbti savo darbą ${ }^{124}$.

Komendantui remiant, anketos pildymo metu paaiškèjo būdas, taikytinas žmonėms, ypač religingiems, supažindinti su lietuvių kalba - jiems imta gausiai dalyti lietuviškas maldaknyges. Antroje vietoje atsidūrè knygos ir laikraščiai, dalinti per šaulių bibliotekas ir mokyklas. Lietuviškai jau kalbejjo apskrities miestų ir miestelių gyventojai, tačiau sunkiausia buvo pasiekti pasienio kaimų gyventojus, kalbančius lenkiškai, kuriuos visi respondentai vadino „lenkuojančiais“.

A. Smetonos autoritarinio režimo sąlygomis $1934 \mathrm{~m}$. pradžioje valstybès ir visuomeninès institucijos, garsiai ir daug kalbejjusios apie lietuvišką Lietuvą ir raginusios tautines mažumas viešumoje vartoti lietuvių kalbą, skleisdamos lietuvybę nekoordinavo šios veiklos, jai nevadovavo ir veikė tik pavienių tarnybų ir entuziastų, taip pat savo užnugario reikalais besirūpinančių karinių struktūrų dèka. Lenkiškai kalbančius kaimų gyventojus pradèta geriau aprūpinti spauda ir maldaknygèmis lietuvių kalba - tuo rūpinosi kariuomenè, karo komendantūra, Šaulių sąungos bibliotekos ir mokyklos. Tačiau lietuviškų leidinių dalijimo mastas, palyginti su gyventojų skaičiumi, buvo labai nedidelis (apskrityje gyveno per 80000 gyventojų). Net jeigu koks nors lietuviškas leidinys būtų pasiekęs kiekvieną gyventoją (o tai to meto sąlygomis būtų buvęs stebuklas), ar galima teigti, kad tai būtų padarę reikšmingą ịtaką gyventojų tautinėms ir politinems nuostatoms? Gal tai tebuvo savotiškas XX a. ketvirto dešimtmečio „knygnešystès“ fenomenas? Tautinei orientacijai ir lenkakalbių gyventojų lietuviškos tapatybès pasirinkimui poveikis galejo būti tik dèl viso komplekso priežasčių, pirmiausia - dèl Lietuvos valstybès spartaus

${ }^{124} 1936$ m. apie konkrečius savo veiksmus V. Žutautas rašè: „Nuo 1933 m. tapęs Trakų apskrities komendantu ir pažinęs to krašto stovị ir jo kultūrinius sunkumus dejjau pastangų savo ploto [kaimų] gyventojus šviesti ir kultūrinti. Viena iš tokių priemonių buvo susitarimas su Divizijos vadu, pagal kuri jo buvo ịsakyta pulkams atliekamus nuo renkamų i k komplektus „Kario“ „Trimito“ „Ūkininko patarèjo“ ir pan. N. N. per Div. Štabą siuntimas man. Aš per šaulių būrius ir pradžios mokyklas siunčiu tą medžiagą $\mathfrak{i}$ kaimus. Kiek teko girdèti iš mokytojų, toji spauda yra nemažą naudą atnešusi. Kaimas, kuris nèra skaitęs ir matęs lietuviškų laikraščių - pamatè mūsų gražią ir turiningą spaudą. Paveikslèliai patraukè jų dėmesį; buvęs karys arba pradžios mokyklos lankytojas tėvams perskaito ir išverčia <...> Trakų apskrityje spaudos buvo išrašoma 1933 m. 5462 egz., 1934 m. 6580; 1935 m. 8154 egz. Net ir ūkiški sunkumai nesulaiko juose kylančio [tautinio] susipratimo <...> “ Žr.: Plk. V. Žutauto 19360114 pranešimas Lietuvos kariuomenès Vyr. štabo II skyriui. LCVA, f. 500, ap. 1, b. 406, 1. 192. 
kultūrinio ir ekonominio augimo XX a. 3-4 dešimtmetyje, stiprèjančio Lietuvos valstybès autoriteto gyventoju akyse, tarnybos Lietuvos kariuomenejje, galimybių dalyvauti vietos visuomeniniame gyvenime (seniūnijų, valsčių mastu), mokyklų ir kunigų daromo poveikio lietuvybės labui.

\section{LITERATŪRA}

Lietuvos centrinis valstybès archyvas (LCVA), f. 500, ap. 1, b. 406, 1933-1934 m. tyrimo Trakų apskrityje medžiaga, saugoma Trakų apskrities karo komendanto 500 fonde.

Buchowski Krzysztof. Litvomanai ir polonizuotojai. Mitai, abipusès nuostatos ir stereotipai lenkų ir lietuvių santykiuose pirmoje XX amžiaus puseje, Vilnius, 2012, $603 \mathrm{p}$.

Eidintas Alfonsas, Lopata Raimundas. Valstybès atkūrimo istorijos, Vilnius, 2019. Žr. paskutinị A. Eidinto parašytą knygos skyrių apie Lietuvos kariuomenès ir lenkakalbių gyventojų santykius.

Gaučys Povilas. Tarp dviejų pasaulių. Iš mano atsiminimų 1915-1938, Vilnius, 1999, 372 p.

Ivanovas Bernaras. Tautiškumo beieškant Antano Smetonos Lietuvoje. Tautinių ịvaizdžių klausimas, Vilnius, 2005, 344 p.

Jokubauskas Vytautas, Vaičenonis Jonas, Vareikis Vygantas, Vitkus Hektoras. Valia priešintis: paramilitarizmas ir Lietuvos karinio saugumo problemos, Klaipèda, 2015.

Kaubrys Saulius. Lietuvos mokykla 1918-1939 m.: galios gimtis, Vilnius, 2000, 290 p.

Laurinavičius Česlovas . Politika ir diplomatija: lietuvių tautinès valstybės tapsmo ir raidos fragmentai, Kaunas , 1997, p. 249-250.

Lukoševičius Olijardas. Palomenès istorija: XX amžius, Kaišiadorys: Kaišiadorių muziejus, 2015, 320 p.

Lukoševičius Olijardas. Trakų (Kaišiadorių) apskritis 1918-1940 m.: tarp valdžios ir savivaldos, Kaišiadorys: Kaišiadorių muziejus, 2019, p. 748.

Savanorių žygiai. Nepriklausomybès karų atsiminimai. Sudarytojas Petras Ruseckas. 1-2 t., Vilnius, 1991.

Mačiulis Dangiras, Staliūnas Darius. Vilnius - Lietuvos sostinè: problema tautinės valstybės projekte (XIX a. pabaiga - $1940 \mathrm{~m}$. ), Vilnius: LII leidykla, 2015, $324 \mathrm{p}$. 
1 priedas

\section{„Mūsų su lenkais pasienio tyrimo reikalu ${ }^{125}$}

Mūsu pasienio su lenkais ištautëjimas sudaro nenaudinga valstybei reiškinį ir juo reikia susirūpinti. Tas reiškinys ištikus pavojui gali priešininkui padeti:

1. Per lenkuojančius agentus komplektuoti; palengvina priešui ir mums apsunkina žiniu rinkimo darbus.

2. Apsunkina bendrai sienos apsaugos darba.

3. Priešui įsiveržus ị mūsų teritoriją, tokie išgamos gali persimesti priešo pusèn ir darys žala mūsų kraštui.

Tenka susirüpinti ir atversti paklydèlius. Prie to valdžios einama. Bet kad gydyti, reikalinga žinoti ligos priežastis, simptomus ir pasirinkti tinkamiausias iš eilès priemones.

Taigi reikalinga turèti medžiagos, rimtos, patikrintos ir paremtos faktais-pavyzdžiais.

Šis darbas išpildomas tokiu būdu:

a) Galima tiksliau apibūdinti tikra padètí;

b) İvertinti dabartinę lietuviškumo akciją;

c) Paduoti duomenu kitoms tinkamoms priemonems;

d) Apibūdinti lenkiškojo elemento reakcijas (priešingumo) priemones lietuviškumui;

e) Kokiom priemonèm veikia lenkinimo „apaštalai“;

f) Kas patraukia nutautèjusius ị lenkiškumo vaga (kokie nors pažadai, baimè, dovanos, paskolos, pašalpos...)?

\section{Dèl tikros padèties}

a) Labai svarbu turèti žiniu valsčiais (jei galima tai valsčiais ir kaimais) skaitlinemis nurodant.

1) Kiek yra oficialiai lenkais užsirašiusių,

2) Kiek lenkuoja ir nemoka lietuviškai. Apibüdinti kai kuriuos miestelius ir kaimus lietuvybès atžvilgiu,

${ }^{125}$ Anketos tekstas. LCVA, f. 500, ap. 1, b. 406, 1. 267-269. 
b) Vietos gyventoju santykiai su ana puse administracijos: propaganda (agitacija), kontrabanda, sienos perèjimo motyvai ir t. $t$.

c) Išaiškinti medžiaginę būklę: kas geriau ar blogiau pas mus ir pas lenkus.

d) Kuriu galima rasti mums tinkamu ekonomišku motyvu naudingai propagandai ir kitokiai akcijai (jvairūs mokesčiai, gyventoju presijos, keliu taisymas, nuostoliu mokejjimas, rekvizicijos ir t. t.).

\section{Lietuviškumo akcijos įvertinimas}

\section{Per kariuomenę:}

a) Ar lenkuojantis elementas grįžta iš kariuomenès pakankamai sulietuvintas.

b) Ar toks buvęs karys nepasiduoda vèl senai namų dvasiai ir nutautéjusių itakai.

c) Kiek tokie buvę kariai yra valstybiškai nusistatę.

d) Ar užtektinai jie bus rangūs paskelbus mobilizaciją.

e) Kiek iš lenkuojančiu šeimu kilę kariai patys varo ar padeda varyti lietuvinimo darba (kūrimas lietuvišku organizacijų, elgesys lietuv. sueigose, gegužynèse, vakaruškose, ar noriai dainuoja lietuviškas dainas ir t. t.).

f) I ka auklejant kariuomenès dalyse lenkuojančius jaunuolius tektu kreipti ypatingo demesio. Kuriu jiems pamokymu ar nurodymu duoti lietuviškumo darbui dirbti grįžus iš kariuomenès.

\section{Per valdžios įstaigas}

a) Savivaldybès organai:

Kiek renkamuju i savivaldybę organu patenka lietuviu, lenku ir kitu; kur vyrauja lietuviškas ir kur lenkiškas elementas. Kokiu yra nesusipratimų. Kiek išrinktas lenkiškas elementas yra valstybinio nusistatymo ir t. t.

b) Pasus tvarkantieji organai:

Kaip gyventojai registruojami pasus ir liudijimus išduodant ar gyventojus surašant; kaip praktiškai sprendžiama tautybès klausimas; ar vadovaujamasi vien gyventoju pareiškimais ar vartojamas kuris nors spaudimas, ar kaip kitaip... 
Ar tokie atsitikimai tinka ar netinka bent formaliai kraštui lietuvinti. Kokị vaidmenị bendrai tokie organai gali vaidinti krašto lietuvinimo darbe, kas darytina, kad jie galettu praktiškai tokị darba dirbti.

c) Ar administracijos organai įpareigoti ar ne kurị nors praktiška lietuvinimo darba dirbti, kuri ir kaip; kokios yra gaunamos ir duodamos tuo reikalu instrukcijos, nurodymai ir t. t. Kokiu pageidavimu galima statyti administracijos organams (apskr. viršininkui, policijos vadui, pasienio apsaugos viršininkui ir pan.).

\section{a) Per ịvairias viešas organizacijas \\ b) Šauliu sajunga:}

Kokios bendrai pasieny šauliu sajungai veikti salygos; kiek tas darbas praktiškai išplesstas (kur kokie skyriai yra, kiek nariu turi, kas darbui vadovauja; ar istoja i sajunga ir kiek lenkuojančiu, kaip jie priimami, koks tikslas ju istojimo, kaip jie laikosi ir t. t.).

Kokiu priemoniu kraštui atlietuvinti imasi šauliu sajungos skyriai pasienio srity.

c) Ar yra kurios nors kitos tinkamos lietuvinimo darbui organizacijos ir kokios.

\section{Ivairūs kiti šaltiniai}

Veikimas privačiu vietoje gyvenamu asmenu, visuomenès veikejju, gydytoju, advokatu, teisèju, mok. inspektoriu, notaru, Ž.U. Rūmu atstovu, agronomu ir kariuomenes.

\section{Valstybès savivald. ir stambių organizaciju prisidèjimas}

Kuo, kurie šie organai galètu büti naudingi; konkrečiu priemoniu reikèty imtis (privilegijos, presijos ir kokios bütent).

\section{Lenkiškojo elemento reakcijos lizdai:}

1. Ar yra ir kiek lenkišku mokyklų: valdžios ar visuomenès lëšomis išlaikomu; kaip tos mokyklos komplektuojamos; ar yra tam tikslui organizuotu lenku propaganda; kurios organizacijos ar asmens ta propaganda 
veda; kaip i ja reaguoja vietos gyventojai.

2. Kitos lenkiškumui palaikyti priemonès:

Spauda: kokie lenkiški laikraščiai ir iš kur gaunami ar siunčiami, išrašomi kolektyviai ar individualiai, kiek. Kokios lenkiškos knygos labiausiai skaitomos. Kokia bendrai pasieny prolenkiška elemento akcija. Kurios organizacijos ypač pasižymi lenkiška propaganda; kokias vartoja priemones.

Kokie motyvai vyrauja tokioje propagandoje, kurie prieštarauja valstybingumo squvokai.

\section{Per mokyklas}

a) Ar mokytojai tautiškai susipratę, ar prisideda prie lietuvinimo darbo ir kaip (ar vadovauja kaimo jaunimui, organizuodami pasilinksminimus, gegužines, spektaklius, paskaitèles), ar per vaikus veikia tèvus, ar lanko šeimas, ar jiems aiškina lietuviškuma ir t. t. Ar užtektinai mokytojai autoritetingi žmonių akyse.

b) Kokia bendrai yra tvarka mokytojams i tą krašta skirti ir kokiu tuo reikalu bütų pageidavimu.

c) Mokytoju sudetis: kiek vyru ir kiek moterų. Kurie geriau tinka, kurie arčiau prie gyventoju moka prieiti ir vietiniu žmoniu simpatijas patraukia. Kokio amžiaus mokytojai labiau tiktu dirbti šiame krašte (jauni ar pagyvenę).

d) Nurodyti konkrečius pavyzdžius, kuriuose valsčiuose ir kuriose mokyklose kurie bütent mokytojai pasižymi savo uolumu ir veiklumu kalbamajame darbe; kokiu jie ta atlieka büdu ir kokiomis priemonèmis. Kokiu pageidavimu mokyklų reikalu reiškia ar galètu reikšti vietos gyventojai, mokyklu administracija (mokytojai inspektoriai) valdžios organai; kas bendrai šioje srityje pasiekta ir kas darytina lietuvybès akcijai per mokyklas stiprinti.

\section{Per bažnyčią}

a) kiek dvasininkams yra palankios ir nepalankios salygos prie bendro darbo prisideti: kur ir kokiuose valsčiuose bei parapijose yra vien tik lenkiškos pamaldos, lietuviškos ir maišytos. Kokia tvarka pamaldos (pamokslai, bažnytinès giesmès, chorai, keičiasi lietuviška ir lenkiška kalbos; kas antra šventę, kas 3-čia ar po du pamokslus...ir t. t.), 
b) ar dvasininkai reiškia iniciatyvos, ìvesdami lietuv. pamaldas ar kitaip per bažnyčiq tautiška susipratima ugdo. Kur, kokie dvasininkai tokiu darbu pasižymi ir kur tokio darbo stinga. Kokios priežastys yra teigiamo ir neigiamo darbo,

c) kiek dvasininkai reiškia aktingumo krašto lietuvinimui santykiuose su gyventojais už bažnyčios ribu ir kokia ju yra įtaka. Kokiu pageidavimu bendrai šiuo reikalu reikètu kelti,

d) kokiu jie tą atlieka büdu ir kokiomis priemonèmis. Kokiu pageidavimu mokyklu reikalu reiškia ar galètu reikšti vietos gyventojai, mokyklu administracija (mokytojai inspektoriai) valdžios organai; kas bendrai šioje srityje pasiekta ir kas darytina lietuvybes akcijai per mokyklas stiprinti. "“26

${ }^{126}$ Ten pat, 1. 267-268. 
2 priedas

\section{Trakų (Kaišiadorių) apskritis ir valsčių ribos}

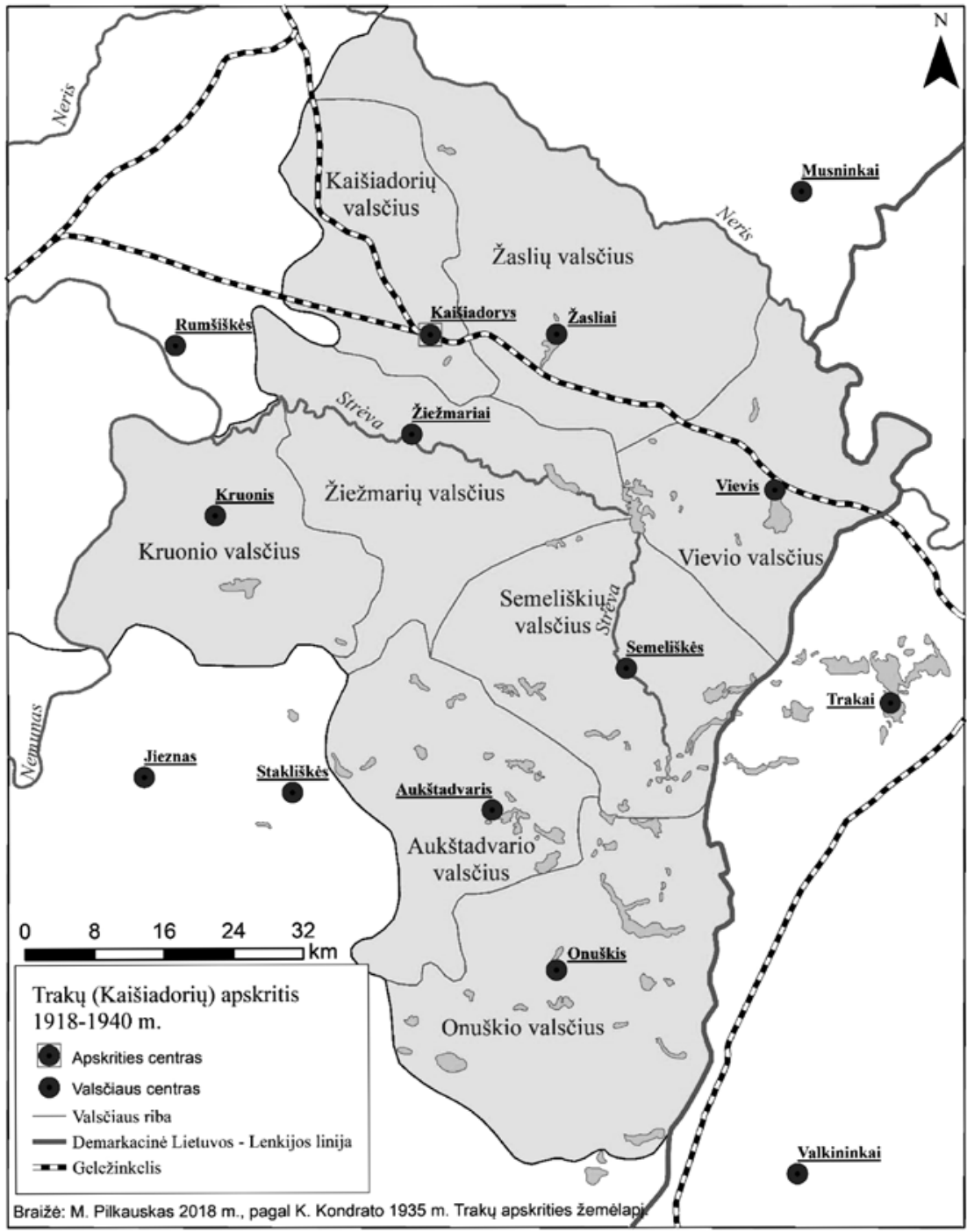


Lietuvos kariuomenès vadovybės $1933 \mathrm{~m}$. pabaigoje-1934 m. pradžioje inicijuotas lenkiškai kalbančių Trakų (Kaišiadorių) apskrities gyventojų tyrimas

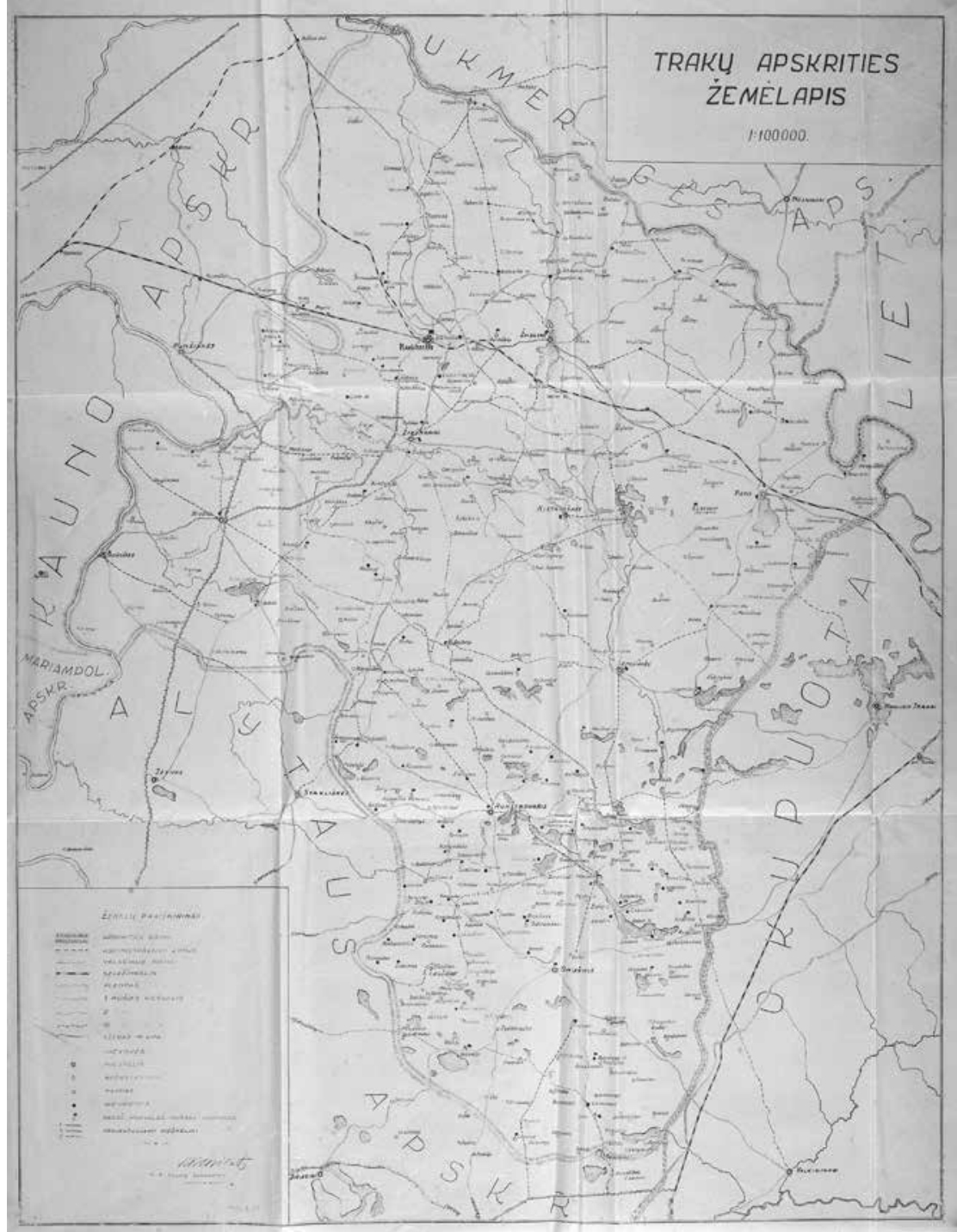

